\title{
Współczesny regionalizm Bliskiego i Dalekiego Wschodu
}

\author{
Redakcja naukowa \\ Joanna Marszałek-Kawa \\ Grzegorz Kądzielawski
}




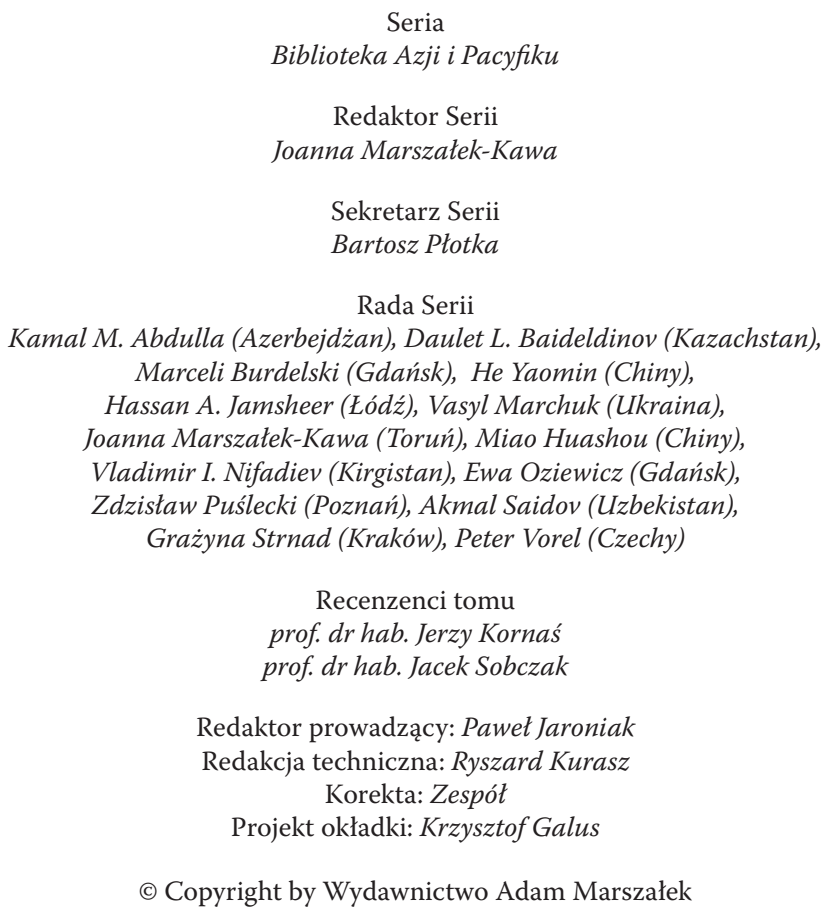

(C) Copyright by Wydawnictwo Adam Marszałek

\begin{abstract}
Wszystkie prawa zastrzeżone. Książka, którą nabyłeś, jest dziełem twórcy i wydawcy. Żadna jej część nie może być reprodukowana jakimkolwiek sposobem - mechanicznie, elektronicznie, drogą fotokopii itp. - bez pisemnego zezwolenia wydawcy. Jeśli cytujesz fragmenty tej książki, nie zmieniaj ich treści i koniecznie zaznacz, czyje to dzieło
\end{abstract}

Toruń 2020

ISBN 978-83-8180-314-4

Wydawnictwo prowadzi sprzedaż wysyłkową: tel./fax 566485070 , marketing@marszalek.com.pl

Wydawnictwo Adam Marszałek, ul. Lubicka 44, 87-100 Toruń tel. 5666422 35, 5666081 60, e-mail: info@marszalek.com.pl, www.marszalek.com.pl Drukarnia, ul. Warszawska 54, 87-148 Łysomice, tel. 5667834.78 


\section{Spis treści}

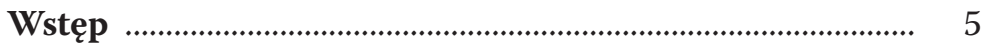

Bogusław Pacek, Karolina Rak

Migracje jako jedno z wyzwań państw azjatyckich

\section{Maciej Szczurowski}

Mity polityczne współczesnej Azji

\section{Patryk Piotr Madej}

Separatyzm cypryjski - wielowymiarowość problemu ......

\section{Olga Lozińska}

Dyplomacja kulturalna Włoch na przykładzie działalności Włoskich Instytutów Kultury w Japonii

\section{Agnieszka Esin Lesiczka}

Nauczanie języka tureckiego w Czechach i na Słowacji ..... 84

\section{Adrianna Czarnecka}

Rola kobiecych jednostek YPJ w walce z tzw. Państwem Islamskim

\section{Grażyna Strnad}

Szczyty międzykoreańskie w okresie prezydentury

Moon Jae Ina 


\section{Jacek Knopek}

Polacy w przestrzeni cywilizacyjnej Półwyspu

Arabskiego

\section{Katarzyna Ciepiela}

Wybory prezydenckie w Indonezji - Jokowi

czy Prabowo?

144 


\section{Wstęp}

Współczesny regionalizm końca XX i w XXI w. postrzegany jest wielowymiarowo. Należy go traktować w kontekście globalizacji rozumianej jako ogólnoświatowa integracja, nie tylko ekonomiczna, ale również w kontekście przeciwstawiania go globalnej unifikacji i eksponowaniu jego istotnej roli w budowaniu światowej konkurencyjności regionów. W rozważaniach naukowych wielu autorów, w tym B. Hettne czy R. Ziemba, uważa, że globalizacja i regionalizm są blisko powiązanymi zjawiskami. Ten ostatni rozwija się dynamicznie, co dowodzi jego światowego zasięgu. Dlatego współcześnie pod pojęciem tym rozumie się współpracę kilku państw, które łączy przede wszystkim bliskość geograficzna. Jednak sąsiedztwo nie jest tu najistotniejszym kryterium. Należy interpretować go także jako wieloaspektowy proces, obejmujący rozmaite powiązane, wielowymiarowe uwarunkowania ekonomiczne, społeczne, polityczne i kulturowe. Ciekawe w tym względzie są rozważania E. Haliżaka, który analizując ów proces, sugeruje, że kształtowanie się współpracy regionalnej przebiega w czerech etapach. Pierwszy rozpoczyna się wraz z pojawieniem się świadomości regionalnej wśród elit i warstw społecznych. Drugi dotyczy ujawnienia wspólnoty potrzeb i interesów społeczeństw zamieszkujących dany region. Ilościowy i jakościowy wzrost pozytywnych interakcji między państwami i społeczeństwami regionu prowadzący do ich regulacji na poziomie instytucjonalnym przebiega w etapie trzecim. Czwarty etap obejmuje pełną integrację państw regionu związaną z przeniesieniem części kompetencji decyzyjnych na poziom regionalny. Znaczenie regionalizmu nabrało nowego kształtu 
politycznego i ekonomicznego szczególnie w okresie, kiedy powrócił on w przestrzeń polityki międzynarodowej po rozpadzie Związku Radzieckiego w 1991 r. i w obliczu kształtowania się nowego ładu międzynarodowego z dominacją Pax Americana. Już wówczas zastanawiano się, czy obok lub zamiast Pax Americana mogą funkcjonować: Pax Islamica - z decydującą rolą państw muzułmańskich po ewentualnym złamaniu amerykańskiej hegemonii we współczesnym świecie albo Pax Sinica - z decydującą rolą ChRL po upadku lub mimo dalszego utrzymywania się mocarstwowej pozycji USA w niektórych regionach: Ameryce Łacińskiej, Afryce, Europie. Azja ze względów gospodarczych i strategicznych, a także w kategorii sporów i konfliktów jest miejscem szczególnym. Geograficzna obecność na tym kontynencie: Chin, Indii, Korei Północnej, Korei Południowej, Japonii, państw Półwyspu Indochińskiego, republik Azji Środkowej powstałych po rozpadzie ZSRR i w końcu państw Bliskiego Wschodu powoduje, że każdy spór, do którego dochodzi na tym obszarze, ma wymiar niebagatelny, a wręcz ogólnoświatowy. Godzi się przypomnieć, że obszar Azji zamieszkuje ponad 60\% ludności świata, a dwa państwa - Chiny i Indie - przekroczyły już liczbę miliarda obywateli. Potencjał demograficzny jest skorelowany z wielkością rynków i rozwojem gospodarczym.

Jego uzupełnieniem jest Bliski Wschód traktowany jako zagłębie surowców, zwłaszcza tych strategicznych. Obok Chin i Indii także Korea stała się obszarem nie tylko regionalnej, ale i globalnej rywalizacji. Funkcjonujące w tym obszarze zarówno Republika Korei, jak i Koreańska Republika Ludowo-Demokratyczna, weszły w strefę wpływów mocarstw. Przy czym Korea Południowa znalazła się w strefie oddziaływania Stanów Zjednoczonych, a Północna przez cały okres zimnej wojny i współcześnie starała się balansować między dwoma potężnymi sojusznikami. Problemom tym poświęcona jest niniejsza 
monografia. Rozpoczyna się ona procesami demograficznymi, gdzie B. Pacek i K. Rak prezentują Migracje jako jedno zwyzwań państw azjatyckich. Natomiast M. Szczurowski analizuje Mity wspótczesnej Azji. Separatyzm cypryjski - wielowymiarowość problemu przedstawia w swoim artykule P.P. Madej. Regionalną rolę w utrzymywaniu stosunków międzypaństwowych prezentuje O. Łozińska w artykule Dyplomacja kulturalna Włoch na przykładzie działalności Włoskich Instytutów Kultury w Japonii. Historia turkologii na ziemiach obecnej Republiki Czeskiej jest dosyć długa, owocna i widoczna w wielu badaniach naukowych. Potwierdza to w swoim artykule $\mathrm{Na}$ uczanie języka tureckiego w Czechach i na Stowacji A.E. Lesiczka. Analizę roli kurdyjskich jednostek kobiecych w walce z tak zwanym Państwem Islamskim, uwzględniającą wojskowy, społeczny i psychologiczny aspekt, zawarła w swoim artykule Rola kobiecych jednostek YPJ w walce z tzw. Państwem Islamskim A. Czarnecka. Szczyty międzykoreańskie w okresie prezydentury Moon Jae Ina i ich wpływ na pokój i stabilizację w tym regionie to treść pracy G. Strnad. Ciekawą analizę historyczno-politologiczną przeprowadził J. Knopek w artykule Polacy w przestrzeni cywilizacyjnej Półwyspu Arabskiego. Wybory prezydenckie z 2019 r. w Indonezji, które były największymi na świecie, gdyż wzięło w nich udział około $192 \mathrm{mln}$ uprawnionych mieszkańców archipelagu, zasługują na uwagę także i ze względów na fakt zaangażowania w nie mediów społecznościowych oraz Internetu, co potwierdza K. Ciepiela w swojej analizie Wybory prezydenckie w Indonezji - Jokowi czy Prabowo?

Joanna Marszałek-Kawa Grzegorz Kądzielawski 



\section{Boguslaw Pacek}

Uniwersytet Jagielloński w Krakowie

ORCID ID: https://orcid.org/0000-0001-81 11-1682

\section{Karolina Rak}

Uniwersytet Jagielloński w Krakowie

ORCID ID: https: / /orcid.org/0000-0003-3954-5772

\section{Migracje jako jedno z wyzwań państw azjatyckich}

\section{Wprowadzenie}

Migracje, czyli procesy zmian miejsca pobytu ludności, przemieszczanie się mniejszych i większych populacji w XXI w. stały się zjawiskiem powszechnym. Zjawisko to nie jest niczym nowym, gdyż migracje występowały w historii od wieków. Ich przyczyny mogą być różnorakie, począwszy od ekonomicznych, wynikających ze złego funkcjonowania państwa, przez turystyczne, religijne aż po polityczne. Migracje można podzielić na kilka rodzajów ${ }^{1}$.

1. stosując kryterium czasowe należy wyróżnić migracje:

a) stałe, gdy dochodzi do trwałej zmiany miejsca zamieszkania,

b) czasowe, gdy dochodzi do zmiany miejsca pobytu na pewien czas, sezonowo,

c) wahadłowe, gdy grupy ludzi regularnie dojeżdżają, np. do pracy do odległego miejsca;

2. stosując kryterium odległości należy wyróżnić migracje:

1 Szerzej zob. www.wbc.poznan.pl/Content/359874/Cabanska_Judyta-rozprawa_doktorska.pdf [dostęp: 18.09.2019]. 
a) wewnętrzne, które polegają na przemieszczaniu się wewnątrz państwa,

b) zewnętrzne, gdy migracja następuje pomiędzy państwami; kontynentalne (gdy te państwa położone są na tym samym kontynencie) i międzykontynentalne;

3. stosując kryterium organizacji migracji można wyróżnić migracje:

a) planowe (np. przesiedlenia do własnego kraju) i żywiołowe,

b) legalne i nielegalne,

c) dobrowolne i przymusowe (deportacje, wysiedlenia, przesiedlenia);

4. stosując kryterium przyczyn migracji należy podzielić je na:

a) religijne,

b) turystyczno-rekreacyjne,

c) zarobkowe,

d) związane z łączeniem rodzin.

Migracje mogą mieć charakter przepływu ludności na dane terytorium, wówczas są to imigracje (łac. immigrare - wprowadzić się) $)^{2}$ lub odpływu ludności, co powoduje nazywanie takiego zjawiska emigracją (łac. emigratio - wyprowadzenie się) ${ }^{3}$. O tym, jak ważne jest to zjawisko dla świata świadczy bezspornie to, że to właśnie imigranci przyczynili się do rozwoju kultury i gospodarki wielu państw, chociażby Stanów Zjednoczonych, czy Kanady, zaludnienia wielkich obszarów Australii, Syberii czy Brazylii (choć nie zawsze z woli migranta), jak również rozpowszechnienia np. języków angielskiego czy arabskiego ${ }^{4}$.

2 www.encyklopedia.pwn.pl/haslo/imigracja;3914293.html [dostęp: 20.08.2019].

3 www.encyklopedia.pwn.pl/haslo/emigracja;3897756html [dostęp: 20.08.2019].

4 Szerzej zob. M.S. Zięba, Zintegrowane podejście do kwestii migracji, [w:] Migracja - wyzwanie XXI wieku, red. M.S. Zięba, Lublin 2008, s. 15. 
Niniejsze opracowanie dotyczy głównie migracji zachodzących na terenie kontynentu azjatyckiego oraz w części migracji z Azji do Europy. Opisywane migracje mają charakter zewnętrzny.

\section{Specyfika migracji państw Azji}

Region Azji jest szczególnie istotny do oceny procesów migracyjnych w świecie, bo to właśnie w regionie Azji i Pacyfiku mieszka ponad połowa światowej społeczności i to na tym terytorium mieszka około 25\% wszystkich migrantów świata.

Kontynent azjatycki już pod koniec XX w. był nękany ruchami emigracyjnymi z przeludnionych państw Azji do Ameryki Północnej i Australii. Pod koniec XX w. wzrosła też migracja wewnątrz Azji. Skala migracji zarówno wewnątrzazjatyckiej, jak i emigracji zewnętrznej jest tak duża, że wiele państw Azji nie może poradzić sobie z jej problemami.

Większość emigrantów opuszczających państwa azjatyckie, jak i przemieszczających się wewnątrz Azji, kieruje się pobudkami ekonomicznymi, szuka poprawy losu dla siebie i swojej rodziny. Azjaci pracują w wielu krajach, w licznych branżach, przeważnie jako personel medyczny, sprzątający, w budownictwie. Są to najczęściej ludzie mało wykształceni, ale nie tylko, ponieważ w ostatnich latach zauważa się wzrost migrantów o wysokich kwalifikacjach.

Migracja z Azji i wewnątrz Azji miała wpływ zarówno na losy Europy, jak również zmieniła też losy całych regionów azjatyckich.

Szeroka migracja z państw azjatyckich na inne kontynenty rozpoczęła się w drugiej połowie XX w. Nastąpiło to po tym, gdy Stany Zjednoczone, Kanada i Australia zrezygnowały z restrykcyjnych zasad przyjmowania do siebie Azjatów. Rozwój gospodarki najbogatszych państw, wzrost inwestycji zagranicz- 
nych i handlu pociągały za sobą potrzeby większej liczby ludzi do pracy i sprzyjały migracji. Główne kierunki tej zarobkowej migracji to także Włochy, Wielka Brytania i Węgry. To samo dotyczy przemieszczania się ludności wewnątrz Azji. Wzrost gospodarczy niektórych krajów spowodował przemieszczanie się do nich większej liczby pracowników (często z rodzinami) z innych państw azjatyckich. Jednym z przykładów jest rozbudowa infrastruktury państw Zatoki Arabskiej i masowe przesiedlanie się tam robotników z różnych regionów Azji. W 2004 r., jak podaje Światowa Organizacja Pracy, Azjaci stanowili tu główną siłę roboczą (od 40-70\%) ${ }^{5}$. Główne państwa, będą źródłem migracji z Azji to: Chiny, Indie, Filipiny, Tajlandia i Wietnam. Są to państwa o dużej liczbie ludności.

Emigranci z Azji to nie tylko nisko wykwalifikowani robotnicy, którzy stanowią większość, ale w XXI w. stale rośnie liczba migrujących ludzi wykształconych. Stąd problem „drenażu mózgów" stał się dla wielu państw istotnym wyzwaniem. Jednak duża różnica $\mathrm{w}$ dochodach państw bogatych w porównaniu do znacznie biedniejszych krajów Azji powoduje, że zjawisko to jest nie do opanowania, choć przynosi ogromne straty państwom azjatyckim. Już pod koniec XX w. aż 40\% emigrantów z Filipin i Sri Lanki posiadało wyższe wykształcenie. Na przełomie XX i XXI w. połowę absolwentów uczelni USA stanowili imigranci z Azji, głównie z Chin i Indii. Ostatnio jednak zauważa się trend odwrotny, to uczelnie z Azji: chińskie czy japońskie rekrutują zagranicznych studentów bądź przyciągają swoich wykształconych za granicą obywateli do powrotu do kraju, proponując różnego rodzaju ulgi i inne udogodnienia.

To, co pogłębia negatywne skutki migracji z Azji, to przede wszystkim brak planowanych działań dotyczących przemiesz-

5 www.psz.pl/168-archiwum/migracje-w-rejonie-azji-i-pacyfiku [dostęp: 16.08.2019]. 
czania się ludności zarówno z, jak i do państw azjatyckich. Problemem jest też brak pełnej kontroli nad migracją.

Jako zagrożenie należy traktować wysoki poziom migracji nielegalnej, która wciąż rośnie. Aż 25\% migrantów funkcjonujących w państwach azjatyckich działa nielegalnie. Dotyczy to głównie emigrantów z Indonezji i Malezji, a wynika z zainteresowania pracodawców pozyskiwaniem taniej siły roboczej oraz chęci omijania podatków. Ta migracja wewnętrzna, w odróżnieniu od emigracji na Zachód związana jest z wieloma zagrożeniami, w tym z brakiem praw migrujących pracowników.

Wyzwaniem wielu państw staje się stopniowa utrata dobrych fachowców. Pracodawcy chętnie przedłużają pobyty, ułatwiają ściąganie rodzin i osiedlanie się na stałe najlepszym i najbardziej wydajnym pracownikom. Słabsi wracają do swoich krajów, a na ich miejsce przybywają nowi. Trwa selekcja, która powoduje, że dzięki migracji bogate państwa rozwijają się jeszcze szybciej, a biedniejsze zostają z problemami słabszego potencjału ludzkiego. Takie kraje, jak Indie, Singapur, Korea Południowa, Japonia posiadają wiele programów motywujących najzdolniejszych obywateli innych państw do podejmowania pracy u nich.

Początek XXI w. pokazał, że problem migracji wzrasta, a nie maleje. Na początku wieku na całym świecie było ponad $172 \mathrm{mln}$ migrantów. Kolejne piętnaście lat przyniosło dalszy wzrost tej liczby i to aż o ponad 40\% i tak w 2015 roku było ich około $244 \mathrm{mln}^{6}$. Po 2015 r. główny kierunek migracji międzynarodowych to nadal rozwinięte państwa Europy, Azji i Ameryki Północnej. W 2015 r. około 50\% migrantów pochodzi z dwudziestych krajów wysyłających, do których należą między innymi Indie, Chiny, Bangladesz, Pakistan, Filipiny, Afganistan, Kazachstan, Indonezja, Palestyna, Syria.

6 M. Matkowska, Wspótczesne problemy migracji w Polsce, „Studia, Prace Wydziału Nauk Ekonomicznych i Zarzadzania” 2015, nr 4, s. 89. 
Przełom wieku i uzyskanie niepodległości przez państwa Azji Centralnej spowodowały w nich liczne problemy gospodarcze. Jednym z istotnych źródeł dochodów ludności byłych republik ZSRR, a obecnie samodzielnych państw takich jak: Kazachstan, Uzbekistan, Tadżykistan, Turkmenistan czy Kirgistan stały się wyjazdy zarobkowe do Rosji. Migracje, szczególnie z Tadżykistanu, Uzbekistanu i Kirgistanu stały się masowe. W 2015 r. w Rosji pracowało $3 \mathrm{mln}$ obywateli Uzbekistanu, ponad 1,2 mln Tadżyków i około 0,6 mln Kirgizów ${ }^{7}$. Pieniądze wysyłane do macierzystych krajów stanowiły główne źródło dochodów ich rodzin pozostawionych w ojczyźnie. W 2013 r. wielkość takich transferów pieniężnych (z Rosji do państw Azji Centralnej) wyniosła prawie 13,6 mld USD, z czego 6,7 mld wysłano do Uzbekistanu, 4,2 mld do Tadżykistanu a 2,1 mld do Kirgistanu ${ }^{8}$.

Również istotne znaczenie zaczęły mieć repatriacje mniejszości narodowych przez państwa Europy. Nie bez znaczenia było także zjawisko przemieszczania się uchodźców do UE.

\section{Demografia i ubóstwo a procesy migracyjne państw azjatyckich}

Istotnym czynnikiem mającym wpływ na migrację w świecie stanowi demografia. Jest to drugi, obok niskiego poziomu życia (ubóstwa), element w największym stopniu wpływający na procesy migracyjne we współczesnym świecie. Sytuacja, w której jedne państwa przeżywają przeludnienie, a inne mają wyraźny brak ludności zapewniającej pełny rozwój państwa, po-

7 J. Lang, Azja Centralna. Kryzys modelu migracyjnego i potencjat oddziatywania na UE, Warszawa 2017.

8 https://www.osw.waw.pl/pl/publikacje/komentarze-osw/2017-04-25/ azja-centralna-kryzys-modelu-migracyjnego-i-potencjał [dostęp: 17.08.2019]. 
woduje przemieszczanie się okresowe lub trwałe dużych grup ludzi. Należy zauważyć, że nie tylko sama liczba ludności (jej nadmiar lub niedostatek), ale także cechy danej populacji (jej struktura, wykształcenie, wiek) również mają wpływ na procesy migracyjne. Sama demografia może być zarówno źródłem potęgi kraju, jak i wywoływać zagrożenia, napięcia i konflikty.

Współczesny świat z jednej strony odnotowuje eksplozję demograficzną, co jest widoczne głównie w niektórych państwach Azji i Afryki, z drugiej zaś przeżywa groźny regres demograficzny - co z kolei dotyczy niektórych krajów Europy. Wspomniana eksplozja demograficzna niesie ze sobą szereg problemów związanych z wyżywieniem ludności, zapewnieniem miejsc pracy, edukacji, opieki zdrowotnej. Wywołuje bezrobocie, tworzenie się dzielnic i regionów biedy, niszczenie środowiska naturalnego. Regres demograficzny, określany jako depopulacja, powoduje brak rąk do pracy, załamanie systemu emerytalnego, wolny wzrost gospodarczy, a co za tym idzie konieczność otwierania się państw na imigrantów.

Duża imigracja często powoduje zmianę składu etnicznego populacji i niesie ze sobą szereg wyzwań religijnych, kulturowych, językowych, obyczajowych. Może dawać szanse, głównie gospodarcze, ale też zagrożenia, w tym bardzo groźne, jak kryminalne i terrorystyczne.

Analizując procesy zmian demograficznych w świecie należy przyjąć, że w najbliższych kilkudziesięciu latach będą one miały duży wpływ na migrację ludności zarówno zewnętrzną, jak i wewnętrzną, głównie w Azji i Afryce. Kontynentem, który będzie zmuszony przyjmować imigrantów jest przede wszystkim Europa. Aktualnie ponad 60\% ludności zamieszkuje w Azji (około 4 mld). 26\% Azjatów ma mniej niż 15 lat, w wieku od 15 do 64 lat jest ponad 65\%. Powyżej 65. roku życia jest tylko 7,6\% ludności Azji. Europa, z 738 mln ludności, stanowi 10,7\% populacji świata, z czego do 15 lat ma 15,4\% ludności, w wieku od 15 
do 64 lat $-68,4 \%{ }^{9}$. Natomiast powyżej 65 . roku życia jest ponad 16\% Europejczyków. Już to porównanie wskazuje na prawdopodobne źródła i kierunki przyszłej migracji. Spośród krajów azjatyckich najmłodszą populację mają: Indie, Pakistan, Afganistan, Bangladesz, Iran. Młode populacje dotyczą także państw Azji Centralnej i Bliskiego Wschodu. Najstarsze populacje w Azji posiadają bogata Japonia, Korea Południowa oraz Chiny.

Aby pokusić się o przewidywania migracyjne warto wskazać na obecne współczynniki dzietności. Najwyższe wskaźniki ( $\operatorname{stan}$ z 2017 r.) mają: Afganistan - 5,12, Jemen - 3,63, Irak - 4,0, Pakistan - 2,62. Najniższe wskaźniki dzietności wskazujące na występowanie zjawiska depopulacji mają: Chiny - 1,6, Japonia $-1,41$, Korea Południowa $-1,26^{10}$. W wielu tych krajach duża liczba ludności żyje na granicy ubóstwa (wydają na przeżycie poniżej 1,25 dolara dziennie). Aktualnie dotyczy to 13,1\% ludności Chin, 32\% ludności Indii, 43\% - Bangladeszu i 18\% ludności Indonezji. W $2008 \mathrm{r}$. na świecie było $568 \mathrm{mln}$ ludzi niedożywionych. Z tego w Chinach - $130 \mathrm{mln}$, Indiach - $224 \mathrm{mln}$, Pakistanie - $43 \mathrm{mln}$, Bangladeszu - $41 \mathrm{mln}$, w Indonezji - $30 \mathrm{mln}$, na Filipinach - $12 \mathrm{mln}$, w Tajlandii - 11mln, Wietnamie - 10 $\mathrm{mln}$. Warto tu wspomnieć również, że np. w Indiach aż 40\% dzieci jest niedożywionych ${ }^{11}$. To wszystko tłumaczy, dlaczego w ostatniej dekadzie właśnie te państwa były głównym źródłem migracji zarówno wewnętrznej, jak i zewnętrznej.

Z problemem niedożywienia związana jest także kwestia braku wody, jej nierównomierne rozmieszczenie. Dwa najbardziej zaludnione kraje świata - Chiny i Indie - posiadają łącznie około

9 „VI Forum Xiangshan”, China Institute for International Strategic Studies, Bejin 2015.

10 www.cia.gov/library/publications/the-word-factbook/rankorder/2127rank.html [dostęp: 12.08.2019].

11 www.unicef.pl/O-nas/Aktualnosci/Glod-problem-całego-swiata [dostęp: 12.08.2019]. 
$10 \%$ światowych zasobów wody (Chiny - 6,5\%, Indie - 4,3\%), co w porównaniu do ich łącznej liczby ludności (około 2,8 mld) wskazuje na wyraźną dysproporcję. Niedobór wody pitnej odczuwa aż 45\% Pakistańczyków, 37\% obywateli Afganistanu i 31\% mieszkańców Indii. Aż 147 mln Chińczyków i 142 mln Hindusów nie ma zapewnionych dostaw czystej wody pitnej. W Indiach co roku umiera około 200 tys. osób, ponieważ używają wody z niebezpiecznych źródeł12. 600 mln Chińczyków i $820 \mathrm{mln}$ Hindusów odczuwa brak wody do sanitariatów.

Państwa Azji borykają się też z problemem bezrobocia. Odsetek niepracującej ludności wynosi:

1. w Afganistanie $-46 \%$,

2. w Iraku $-41 \%$,

3. w Laosie - 37\%,

4. w Pakistanie - 36\%,

5. w Kambodży - 33\%,

6. na Filipinach $-33 \%$, w Indiach $-31 \%^{13}$.

Jednocześnie te kraje mają niski odsetek ludności powyżej 60. roku życia.

Źródłem migracji wewnętrznej w Azji są występujące istotne różnice w rozwoju państw azjatyckich. Chiny, które od lat cieszą się wysokim wzrostem PKB (krajowy produkt brutto) mają, uwzględniając siłę nabywczą PKB, realny wzrost cztery razy mniejszy niż Japonia a Indie - 9 razy mniejszy niż Japonia, Afganistan - 27 razy mniejszy.

Widoczne procesy migracyjne zachodzące w Azji wskazują na tendencje przemieszczania się ludności ze wsi do miast, szczególnie do miast dużych, gdzie są wyższe zarobki

12 www.pulsazji.pl/2019/07/06/niedobor-wody-w-indiach-stanowi-coraz-wiekszy - problem/ [dostęp: 13.08.2019].

13 Szerzej zob. Materiały pokonferencyjne (maszynopis) The impact ofrivalry between China, Russia and the United States on security dynamics in Asia, Maghreb and Europe, 6.10.2018. 
i znacznie wyższy poziom życia ludzi. Na przykład w Chinach w ostatnich trzydziestu latach liczba migrantów przemieszczających się z jednego regionu do drugiego, ze wsi do miast, nawet najbliższych, ale dużych, wynosi około $225 \mathrm{mln}^{14}$.

Na początku XXI w. w slumsach w Indiach, Chinach i Indonezji mieszkało prawie 30\% ludności. Na Filipinach, w Wietnamie i Pakistanie - około 40\%, w Laosie, Kambodży, Bangladeszu - do 70\%, co wynikało z naturalnego dążenia do osiedlania się najchętniej w miastach liczących ponad 10 mln ludności (Delhi, Szanghaj, Bombaj, Pekin, Dhaka, Kalkuta, Karaczi) w poszukiwaniu szansy na uzyskanie pracy i wzrostu poziomu życia.

Istotnym czynnikiem motywującym ludność państw azjatyckich do migracji jest brak w wielu, szczególnie biednych państwach, systemu emerytalnego lub jego słabe funkcjonowanie. Aby zarobić na utrzymanie rodziny i dodatkowo starych rodziców bez emerytury, ludzie zmuszeni są do emigracji w poszukiwaniu dobrze lub przynajmniej lepiej płatnej pracy.

Czynnikami sprzyjającymi migracji są także i inne zjawiska, a spośród nich wymienić należy:

1. starzenie się populacji (Japonia, Korea Płd., Chiny) i brak ludzi do pracy;

2. osłabienie trwałości małżeńskiej, utrzymywanie nieformalnych, często bezdzietnych związków;

3. późne zawieranie małżeństw (często bez dzieci lub z jednym dzieckiem);

4. późne rodzenie pierwszego dziecka oraz przesuwanie się wieku płodności na 30-34 lata;

5. wzrost liczby rodzin z jednym dzieckiem;

6. wzrost długości życia i spadek śmiertelności dzieci;

7. wyraźne zmniejszenie dzietności (poniżej progu zastępowalności kolejnych pokoleń);

14 www.psz.pl/168-archiwum/migracje-w-regionie-azji-i-pacyfiku [dostęp: 16.08.2019]. 
8. zmiana roli kobiety z opiekunki dzieci (strażniczki domowego ogniska) na pracowniczkę, partnerkę mężczyzny, co często powoduje rezygnację z potomstwa lub przekładanie decyzji o urodzeniu dziecka na późniejsze lata.

Istotne też stały się dysproporcje płci. W Chinach, gdzie długo stosowana była polityka "one child family" związana z priorytetowym traktowaniem płci męskiej, często dokonywano aborcji noworodków płci żeńskiej. Stąd w 2020 r. w kraju tym będzie brakowało około $37 \mathrm{mln}^{15}$ kobiet, które mogłyby stać się żonami chcących założyć rodzinę Chińczyków. Powoduje to konieczność poszukiwania żony za granicą (głównie w Wietnamie, Laosie, Korei Płn.). Następuje też wzrost przemocy wobec kobiet, które niekiedy zmuszane są do małżeństwa. Kwitnie też handel kobietami, które często się porywa i sprzedaje jako „materiał” na żonę.

W ciągu najbliższych czterdziestu lat nastąpi spadek liczby ludności: w Japonii o 19\%, w Rosji o 16\%, w Korei Południowej o 12\%. W Japonii w 2050 r. 60\% społeczeństwa będzie w wieku poprodukcyjnym. Zmaleje też liczba ludności w Unii Europejskiej (do 2050 r. - o około 19 mln). Największy spadek liczby ludności odnotują: Polska, Niemcy, Wielka Brytania, Dania, Holandia, Szwecja, Bułgaria, Rumunia, Litwa i Łotwa. W 2050 r. w całej Europie będzie więcej ludności w wieku poprodukcyjnym niż pracujących.

Biorąc pod uwagę powyższe ustalenia należy ocenić, iż następne dekady XXI w. przyniosą liczne zmiany w funkcjonowaniu światowej społeczności. Wiek XX oznaczał w wielu obszarach dominację Europy i Ameryki Północnej, XXI w. przynosi dominację Azji, wzrost jej znaczenia oraz uzależnienia rozwoju Europy i Ameryki Północnej od państw azjatyckich. Euro-

15 Szerzej zob. www.wiadomoscionet.pl/swiat/radoslaw-pyffel-konsekwencje-polityki-jednego-dziecka-to-bomba-z-opoznionym-zaplonem/ c052h [dostęp: 26.08.2019]. 
pejskie i amerykańskie czy kanadyjskie rynki pracy nie obejdą się bez imigrantów. Już dziś jeden na siedmiu amerykańskich zatrudnionych urodził się poza USA ${ }^{16}$. Jednym z wyzwań dla Azji stanie się migracja zarówno wewnętrzna - zachodząca w krajach azjatyckich i pomiędzy nimi, jak i zewnętrzna - do państw Europy i Ameryki Północnej.

\section{Zakończenie}

Trudno przewidzieć w sposób szczegółowy przyszłe procesy migracyjne, ale z całą pewnością będą one miały istotny wpływ nie tylko na losy samych migrantów, ale i na rozwój zarówno państw Azji, jak i Europy oraz Ameryki Północnej. Szybko rozwijająca się demograficznie Azja, przy mniejszym wzroście populacji Ameryki Północnej i kurczeniu się Europy oznacza konieczność podjęcia wielu wyzwań migracyjnych, nie tylko w państwach Azji, ale także na innych kontynentach.

W regionie Azji Centralnej i Chin wyzwaniem musi stać się zaprzestanie degradacji środowiska naturalnego przez przemysł wydobywczy, znalezienie sposobu na ograniczenie niedoboru wody pitnej czy zanieczyszczenia wód gruntowych. Tymczasem Chiny chcą budować zapory wodne i kanały, co znacząco może wpłynąć na jeszcze większy niedobór wody (proces ten może dotyczyć $430 \mathrm{mln}$ ludzi zamieszkujących wzdłuż rzeki Jangcy i jej dopływów) ${ }^{17}$, a co za tym idzie, spowodować kolejne migracje ludzi uciekających od niesprzyjających lub wręcz uciążliwych warunków życia.

Z problematyką migracyjną należy powiązać również wzrost przestępczości, szczególnie w wielkich miastach i ich obrzeżach,

16 https://www.migrationpolicy.org/research/immigrants-and-labor-force-trends-future-past-and-present [dostęp: 19.08.2019].

17 Chiński smok jest spragniony, www.polska-azja.pl/2015/04/17/t-targanski-chinski-smok-jest-spragniony/ [dostęp: 25.08.2019]. 
gdzie zadomawiają się migranci wewnętrzni, ze wsi i okolic, nie mając jakichkolwiek warunków godnego życia i tu wyzwaniem dla państwa staje się zapewnienie bezpieczeństwa fizycznego, socjalnego i podstawowych praw człowieka tej grupie ludności, która często żyje w slumsach, bez możliwości zabezpieczenia podstawowych potrzeb, bez prawa zakupu mieszkania ${ }^{18}$, narażona na wpływy różnych grup przestępczych (np. narkotyki), najogólniej mówiąc - jako obywatele drugiej kategorii.

XXI w. to również wiek wyzwań klimatycznych i związanych z nimi migracji klimatycznych ${ }^{19}$. Dotkną one na pewno kraje Azji Południowej, gdzie ekstremalna pogoda, susza, wysokie temperatury bądź ulewne deszcze będą niszczyć rolnictwo i prowadzić do ubóstwa pracujących na roli, którzy będą emigrować z trudnych terenów albo na inne tereny w obrębie własnego kraju, lub poza jego granice.

\section{Bibliografia}

Chiński smok jest spragniony, www.polska-azja.pl/2015/04/

17/t-targanski-chinski-smok-jest-spragniony/.

http://blogs.wsj.com/chinarealtime/2013/01/17/eight-questions-tom-miller-chinas-urban-bilion

https://www.migrationpolicy.org/research/immigrants-and-

-labor-force-trends-future-past-and-present.

https://www.osw.waw.pl/pl/publikacje/komentarze-osw/2017 -04-25/azja-centralna-kryzys-modelu-migracyjnego-i-potencjał. Lang J., Azja Centralna. Kryzys modelu migracyjnego i potencjat oddziatywania na UE, Warszawa 2017.

18 Szerzej zob. http://blogs.wsj.com/chinarealtime/2013/01/17/eight-questions-tom-miller-chinas-urban-bilion [dostęp: 18.08.2019].

19 www.next.gazeta.pl/next/7,151003,25051135,klimatyczny-apartheid-wpusci-miliony-ludzi-w-biede-i-wymusi-migracje.html [dostęp: 20.08.2019]. 
Matkowska M., Wspótczesne problemy migracji w Polsce, „Studia, Prace Wydziału Nauk Ekonomicznych i Zarzadzania” 2015, nr 4.

www.cia.gov/library/publications/the-word-factbook/rankorder/2127rank.html.

www.encyklopedia.pwn.pl.

www.next.gazeta.pl/next/7,151003,25051135,klimatyczny-a-

partheid-wpusci-miliony-ludzi-w-biede-i-wymusi-migracje.html.

www.psz.pl/168-archiwum/migracje-w-rejonie-azji-i-pacyfiku.

www.unicef.pl/O-nas/Aktualnosci/Glod-problem-całego-swiata.

www.wbc.poznan.pl/Content/359874/Cabanska_Judyta-rozprawa_doktorska.pdf.

www.wiadomoscionet.pl/swiat/radoslaw-pyffel-konsekwencje-polityki-jednego-dziecka-to-bomba-z-opoznionym-zaplonem/c052h.

Zięba M.S., Zintegrowane podejście do kwestii migracji, [w:] Migracja - wyzwanie XXI wieku, red. M.S. Zięba, Lublin 2008.

\section{Abstrakt}

Migracje są istotnym zjawiskiem towarzyszącym rozwojowi społeczeństw od wieków. Od dawna ludzie przemieszczali się, głównie w poszukiwaniu lepszych warunków do życia zarówno wewnątrz swych krajów, jak i udając się do innych państw, czasami bardzo odległych. Współczesne migracje, w tym także te, które zachodzą w Azji również swoje przyczyny znajdują głównie w warunkach socjalnych.

Migracje dotyczące państw azjatyckich są ściśle związane z biedą występującą w części tych krajów oraz z dużymi skrajnościami demograficznymi. Szybki przyrost ludności, przeludnienie w niektórych państwach Azji będą w przyszłości powodować opuszczanie swoich 
krajów i udawanie się do innych państw Azji oraz do Europy i Ameryki Północnej. Artykuł przedstawia wyzwania związane z migracjami, które są obecnie zjawiskiem w Azji oraz migracjami przewidywanymi w przyszłości.

Słowa kluczowe: migracje, państwa azjatyckie, ubóstwo, demografia, przeludnienie

\begin{abstract}
Migrations have been significant phenomenon in the development of societies for ages. For a long time people relocate within their counties a well as outside in order to have better living conditions. Modern migrations including these occurring in Asia are caused mainly by social conditions.

Migrations concerning Asian countries are closely linked first of all to poverty in some countries and secondly to demographic extremes. Fast population growth, overpopulation in certain countries will cause in the future the tendency to leave their motherlands and travel to different countries in Asia, Europe and the North America. This paper shows the challenges concerning migration issues which are the modern phenomenon in Asia and its future development.
\end{abstract}

Keywords: migration, Asian countries, poverty, demography, overpopulation 


\section{Mity polityczne współczesnej Azji}

Sferę duchową społeczeństw dopełniają mity. Nie zawsze doceniamy ich znaczenie, ale odgrywają one ważną rolę, także w przestrzeni politycznej. Służą między innymi skupieniu społeczeństw wokół określonych wartości, celów, wyobrażeń ${ }^{1}$. W ich upowszechnianiu konstytutywną rolę odgrywa czynnik emocjonalny. Mit polityczny jest swoistą formą idei politycznej. Z uwagi na ogromną różnorodność kulturowo-polityczną, kontynent azjatycki pozostaje w kręgu szczególnego zainteresowania zagadnieniami dotyczącymi charakteru i roli jaką mają do spełnienia w praktyce mity polityczne. Podejmowanie prób analizy tych zagadnień zapewne będzie skutkować lepszym zrozumieniem kierunków polityki formułowanych przez społeczeństwa i przywódców tego największego z kontynentów.

Mit polityczny możemy zdefiniować jako swoistą formę idei politycznej, opierającą się nie na wiedzy racjonalnej i empirycznej, lecz na instynktownej wierze w twierdzenie dotyczące świata polityki. Konstytutywną rolę w upowszechnianiu mitu stanowi czynnik emocjonalny, głównie zaspokojenie ludzkich oczekiwań, potrzeb, uczuć. Jednocześnie mit niejako legitymizuje podejmowanie określonych działań politycznych. Mity integrują, dają poczucie wspólnoty, tożsamości, także skutkują

1 M. Szczurowski, Mity, symbole, rytuaty a żotnierz polski w przestrzeni politycznej II wojny światowej, Toruń 2013. 
poczuciem pozornego bezpieczeństwa ${ }^{2}$. Mit raz objawiony, staje się prawdą niepodważalną. Wierzymy w mity, bo chcemy w nie wierzyć. „Tak jest, albowiem powiedziano, że tak jest” - możliwie najprościej charakteryzuje mit rumuński historyk religii, religioznawca, indolog, filozof kultury Mircea Eliade 3 . Podobnie twierdzi inny autor: „Mit jest zatem prawdziwy, bo jest skuteczny, a nie dlatego, że daje nam informacje o faktach"4. Stanisław Filipowicz twierdzi, że „mit wyklucza interpretacje, uwalnia od obowiązku samodzielnych poszukiwań, ujawnia prawdę definitywną, likwidując tym samym potrzebę refleksji”5. Mit narzuca pewne wartości jako jednoznaczne. Stanowi skuteczny instrument psycho- i socjoinżynieryjnych oddziaływań. Stwarza sugestywność jednoznaczną, samorzutnie formułuje ludzkie postawy i zachowania ${ }^{6}$.

Mity polityczne pozwalają usankcjonować przemoc zwłaszcza w sferze stosunków międzynarodowych. Mit walki z terroryzmem od lat uzasadnia politykę międzynarodową Stanów Zjednoczonych, w tym najniższe pobudki zemsty Amerykanów na narodzie afgańskim za zamach z 11 września 2001 r. Mit zagrożenia bronią chemiczną pozwolił tymże Amerykanom podjąć próbę zniewolenia Iraku, w imię osiągnięcia planowanych korzyści ekonomicznych, głównie za sprawą irakijskich złóż ropy naftowej. Mit polityczny mówi o rzekomo ekspansywnej polityce Chińskiej Republiki Ludowej skierowanej przeciwko i zagrażającej bezpieczeństwu oraz interesom amerykańskim w regionie Pacyfiku. Współczesne mity polityczne w znacznym stopniu fałszują azjatycką rzeczywistość,

2 T. Biernat, Mit polityczny, Warszawa 1989; S. Filipowicz, Mit i spektakl władzy, Warszawa 1988.

3 M. Eliade, Sacrum. Mit. Historia, Warszawa 1993, s. 110.

4 K. Armstrong, Krótka historia mitu, Kraków 2005, s. 13.

5 S. Filipowicz, op. cit., s. 22.

6 Ibidem, s. 52. 
zarówno te, które powstały w Azji na potrzeby wewnętrzne tamtejszych społeczeństw, jak i te utworzone na potrzeby polityki w przestrzeni międzynarodowej. Wobec ich ilości warto przyjrzeć się chociażby niektórym z nich.

Jak już wspomniałem, Azja to ogromny obszar chrakteryzujący się szczególną wielokulturowością. Z wymienianych przez Samuela Huntingtona dziewięciu współczesnych kręgów cywilizacyjnych, aż sześć obejmuje kontynent azjatycki ${ }^{7}$ Są to przypomnę cywilizacje: prawosławna, islamska, hinduistyczna, buddyjska, chińska i japońska. Huntington, z uwagi na znikomą liczebność narodu i specyficzny dar asymilacji, nie wyróżnia cywilizacji żydowskiej. My jednak, w kontekście analizy zjawisk natury kulturowo-politycznej Azji nie możemy jej pomijać. W toczącej się nie tylko w kontekście kontynentu azjatyckiego dyskusji na temat pierwotnej i wtórnej funkcji kultury i cywilizacji, warto odnotować, że np. niemiecki filozof kultury i historii Oswald Spengler terminy „kultura” i „cywilizacja” używa do oznaczania różnych faz tego samego procesu ${ }^{8}$. Dopóki rozwija się i kwitnie, jest kulturą, gdy przestaje być twórczą i wyczerpuje się, staje się cywilizacją. Zatem skoro cywilizacja następuje po kulturze, to Spengler nie uważał za cywilizacje zmitologizowanych i żyjących w specyficznej religijności społeczności takich krajów, jak Indie czy Chiny. Natomiast zupełnie inny pogląd głosił Mahatma Gandhi, uznając za cywilizacje właśnie funkcjonujące w sferze mitów społeczeństwa obu tych mocarstw ${ }^{9}$.

Wszyscy z zainteresowaniem, często z niepokojem, obserwujemy światowe procesy globalizacyjne, narzucanie społe-

7 S. Huntington, Zderzenie cywilizacji i nowy ksztatt tadu światowego, Warszawa 1997, s. 56.

8 O. Spengler, Zmierzch Zachodu. Zarys morfologii historii uniwersalnej, Warszawa 2001.

9 J. Justyński, Społeczeństwo i państwo w ideologii ,indyjskiego renesansu, „Czasopismo Prawno-Historyczne” 1973, t. XXV, z. 2, s. 141-159. 
czeństwom systemu wartości i norm neokultury medialnej, właściwej dla euroatlantyckiego kręgu cywilizacyjnego. To, co dla Europejczyka (także tego z Europy Wschodniej) jest zjawiskiem czy wartością akceptowalną lub przynajmniej niebudzącą sprzeciwu, w innych społeczeństwach z wielu powodów jest nie do przyjęcia. W katalogu norm społecznych dużą rolę odgrywa tradycja i wartości filozoficzno-religijne. To one w dużej mierze mają wpływ na kształtowanie się etniczności narodów identyfikujących się ze sobą w oparciu o wspólne doświadczenia społeczne, kulturowe, narodowe oraz historyczne. Przynależność do grupy etnicznej najczęściej wiąże się ze wspólnym dziedzictwem kulturowym, językiem, strukturą społeczną, wierzeniami i szeregiem rytuałów dnia codziennego. Wytworem kultury pozamaterialnej społeczeństw są mity. Każda grupa społeczna, każdy naród tworzy własną mitologię, w którą wierzy i z którą się utożsamia.

Ingerując w etniczność społeczeństw Azji musimy pamiętać, że na kontynencie mamy do czynienia z niezwykle zróżnicowanym i barwnym konglomeratem społeczności. Począwszy od Indii, które uznaje się za źródło wszelkiej kultury. Dla milionów ten kraj to światowy ośrodek duchowy, miejsce odnowy moralnej i największy autorytet. Jest również na kontynencie azjatyckim uważana za największą i najliczniejszą w świecie chińska grupa etniczna Han, licząca ponad 1,3 mld ludzi. Są setki, jeśli nie tysiące mniej lub bardziej licznych grup. Współczesna tożsamość kulturowa Azjatów to w dużym stopniu wartości islamu, ale również odwoływanie się do neokonfucjanizmu i poszanowanie zasad trybalizmu. To owe prawa mają zasadniczy wpływ na kształtowanie się współczesnych mitów politycznych w Azji.

Część intelektualistów azjatyckich zadaje pytania o sens troski o rodzimą kulturę, o wartości duchowe skoro powszechnie akceptowane jest przejmowanie w sposób nierefleksyjny 
obcych kulturowo zjawisk w postaci produktów wielonarodowych kompanii medialnych na czele z show biznesem. Często spotyka się opinie o nadmiernej okcydentalizacji Azji Wschodniej, czyli przyjmowaniu wzorców kultury krajów cywilizacji zachodniej, a zwłaszcza amerykańskiej, i powszechna ich akceptacja. Synonimem okcydentalizacji jest „westernizacja”.

Nie tylko w odniesieniu do Azji mówi się o trzech opcjach stosunku do okcydentalizaji: akceptacji, odrzuceniu i modernizacji. Bez wątpienia o akceptacji westernizacji możemy mówić w przypadku Japonii, Korei Południowej czy Tajwanu. Odrzucono okcydentalizaję w Turcji i tych państwach, gdzie przeważa radykalizm islamski. Natomiast opcja, która polega na wprowadzaniu modernizacji przy zachowaniu podstawowych wartości, zwyczajów i instytucji rodzimej kultury, jest najpopularniejsza między innymi w Chinach. W Państwie Środka następują sukcesywne przeobrażenia także w sferze kultury niematerialnej. To, że nie następują natychmiast i w sposób radykalny, to kwestia tradycji i wyboru chińskiej drogi przeobrażeń kulturowych. $Z$ tego powodu nie na miejscu jest chociażby zarzut, że władze ChRL ograniczają dostęp do Internetu. Powszechnie wiadomo, że Internet $i$ temu podobne media są wykorzystywane przez Zachód, a zwłaszcza Stany Zjednoczone do propagowania swoich wartości kulturowych, które nie zawsze są w zgodzie z wartościami etyczno-moralnymi azjatyckich społeczeństw, a ponadto te społeczeństwa nie są jeszcze mentalnie przygotowane na "zderzenie cywilizacyjne” z kulturą Zachodu.

Jak twierdzi Krzysztof Gawlikowski społeczeństwa Zachodu oraz Azji różni typ struktury organizacyjnej. Pierwsze opierają się na założeniu równości ludzi oraz stosunkach partnerskich pomiędzy jednostkami. Drugie z kolei charakteryzuje hierarchiczny porządek społeczny. Status jednostki określany jest przez jej miejsce wewnątrz grupy oraz pozycję danej grupy 
w społeczeństwie. Jednostka winna jest szacunek i posłuszeństwo osobom zajmującym wyższą od niej pozycję. Natomiast jednostki o randze nadrzędnej pełnią funkcję kierowniczą i opiekuńczą. Liderzy muszą mieć stałe poparcie podwładnych i nie mogą niczego narzucać arbitralnie, ponieważ najwyższym ideałem jest utrzymanie harmonii oraz dobro grupy ${ }^{10}$.

Wspomniany Samuel Huntington stawia tezę, że modernizacja bynajmniej nie musi oznaczać westernizacji. Modernizacja może stać się narzędziem umacniania miejscowych kultur, a tym samym osłabiania względnej siły Zachodu. Amerykanin twierdzi, że wówczas „świat staje się zasadniczo bardziej nowoczesny i mniej zachodni"11.

Mitowi „końca historii” Francisa Fukuyamy głoszącemu zwycięstwo liberalnej demokracji oraz gospodarki wolnorynkowej i uczynienie ze świata globalnej wioski ${ }^{12}$ został przeciwstawiony singapurski mit „imperium szacunku”, sięgający korzeniami do akceptowanej w regionie myśli społeczno-politycznej określanej jako neokonfucjanizm. Ten ostatni oparty jest na ukształtowanych przez wieki wartościach, jest systemem filozoficzno-religijnym głoszącym, że zbudowanie idealnego społeczeństwa i osiągnięcie pokoju na świecie jest możliwe pod warunkiem przestrzegania obowiązków wynikających z hierarchii społecznej oraz zachowywania tradycji, czystości, ładu i porządku. Odpowiedź na pytanie czy konfucjanizm jest religią, czy filozofią? - jest trudne. Według europejskich kryteriów jest to mieszanka pojęć religijnych, społecznych, ekonomicznych, etycznych i obyczajowych tworzących spójny, choć nie do końca zdefiniowany światopogląd. Duch konfucjanizmu jest obecny w wielu krajach

10 K. Gawlikowski, Dwie cywilizacje i ich wizje człowieka: Zachód i Azja Wschodnia, Warszawa 1997, s. 8-20.

11 S. Huntington, op.cit., s. 115.

12 F. Fukuyama, The end of history and the last man, New York 1992 (wyd. pol. Koniec historii i ostatni człowiek, Kraków 2017 i inne). 
Dalekiego Wschodu wciąż żywy i głęboko zakodowany w świadomości ludzi, spełniając podobną rolę kulturową jak „podstawowe wartości chrześcijańskie" w państwach Zachodu. Zasady konfucjańskie przenikają przez tradycje i światopoglądy adaptowane w poszczególnych państwach tworząc często zaskakujące mieszanki, takie jak np. dżucze - ideologia państwowa obowiązująca obecnie w Korei Północnej ${ }^{13}$.

Po koniec XX w., w miejsce starcia dwóch megasystemów, pojawiły się konflikty, które dotyczą przede wszystkim kwestii dogmatu religijnego, światopoglądowych, ideologicznych, odmienności poglądów na organizację życia politycznego, społecznego i ekonomicznego. Szybko uwidoczniły się głębokie antagonizmy, głównie między centrami cywilizacyjnymi współczesnego świata $^{14}$. Szczególnego charakteru nabrała konfrontacja zstępującego kręgu kulturowego Zachodu ze wschodzącymi cywilizacjami Azji oraz światem muzułmańskim ${ }^{15}$. Ekspansywny charakter zachodniego wzorca demokracji i wypaczony przez ostatnich prezydentów Stanów Zjednoczonych i ich administrację nurt neoliberalizmu, spotkał się ze zdecydowaną negacją i odrzuceniem przez większość społeczeństw azjatyckich. Jedynie pewne elementy zachodnich wzorców kulturowych, w tym stylu życia, są akceptowane przez część azjatyckich społeczności, w tym głównie takich krajów, jak Japonia i Korea Południowa.

W 1993 r. prawnik z wykształcenia, ekspert od spraw polityki międzynarodowej Jean-Marie Guéhenno wydał w Paryżu książkę pt. La fin de la democratie ${ }^{16}$. Dostrzegając zjawisko ekono-

13 W. Jabłoński, Religie Chin, [w:] Trzaska, Evert, Michalski, Religie Wschodu, Warszawa 1938, s. 67-118.

14 S. Huntington, op. cit.

15 Uwzględniając mocno uproszczony obraz owych kręgów.

16 J-M Guéhenno, La fin de la democratie, Paris 1993, wyd. ang. The end of the nation-state, Minnesota 2000, wyd. pol. Przyszłość wolności: demokracja w globalizacji, Kraków 2001. 
micznej globalizacji i eskalacji procesów zależności w gospodarce światowej, doszukiwał się ich azjatyckich korzeni. Guéhenno głosił powstanie kolejnego etapu rozwoju społeczno-politycznego w postaci ekonomicznych potęg azjatyckich. Jednocześnie, świadomie lub nieświadomie, poddawał krytyce współczesną swobodę interpretacji demokracji i wolności w społeczeństwach zachodnich, twierdząc, że skutkuje to konsekwentnym dezawuowaniem roli i znaczenia instytucji publicznych. Stwierdzał, że globalny rynek nie jest w stanie stworzyć wspólnoty politycznej o sile, jaką dotychczas stanowiło państwo.

Opisany przez Guéhenno współczesny obraz społeczeństwa zachodniego kłóci się z głęboko zakorzenioną w przeszłości, tradycyjną postacią społeczeństw azjatyckich, których struktury oparte są chociażby jak w Azji Centralnej na trybalizmie rozumianym jako tendencja do utrzymywania się podziałów i odrębności grup plemiennych, etnicznych, opierającą się na zasadach wspólnotowej lojalności, która zapewnia lub ułatwia przetrwanie w danej społeczności ${ }^{17}$. Wizja świata przedstawiona przez Guéhenno to rzeczywistość, w której społeczeństwa azjatyckie mają prawo czuć się zagrożone procesami globalizacji, natomiast w żadnym wypadku nie stanowią one zagrożenia w wymiarze ogólnoświatowym.

Znawcy problematyki są zgodni, że w miejsce systemów demokratycznych uformowanych w XIX w. pojawiają się różnego rodzaju „układy sieciowe” lub „menedżerskie”, dla których źródłem inspiracji jest Azja ${ }^{18}$. Skutkuje to między innymi powstawaniem wielkich zintegrowanych struktur gospodarczych, a w dalszej kolejności politycznych i kulturowych. Przykładem

17 M. Baczwarow, A. Suliborski, Kompendium wiedzy o geografii politycznej i geopolityce, Warszawa 2003.

18 K. Gawlikowski, Perspektywy demokratycznych przemian w Chinach, [w:] Chiny w XXI wieku. Perspektywy rozwoju, red. W.J. Dziak, K. Gawlikowski, M. Ławacz, Warszawa 2012, s. 223-280. 
może tu być Szanghajska Organizacja Współpracy, ASEAN czy BRICS $^{19}$. Te wielkie transnarodowe twory zdają się stopniowo wypierać czy też wchłaniać państwa narodowe ${ }^{20}$. Za kilkanaście lat Chiny będą największą gospodarką świata, coraz wyraźniej będą zbliżać się do nich Indie. Wśród dziesięciu największych gospodarek świata są jeszcze: Indonezja i Japonia. Chiny i Indie są potęgami ze względu na siłę ekonomiczną i militarną, ambicje polityczne oraz znaczenie regionalne i światowe. Chiny mają największy potencjał gospodarczy. Hindusi są narodem bankierów, rządzą jako emigracja w kilkunastu krajach świata. Bliska obu mocarstwom Rosja, co prawda straciła pozycję potęgi gospodarczej, ale posiada wysoko rozwinięty przemysł nuklearny, zbrojeniowy i kosmiczny. Ponadto Rosja to twierdza prawdziwej, nieskalanej wiary, która broni przed katolicyzmem i dekadencją Zachodu. Ma broń jądrową zdolną zniszczyć świat kilkaset razy. Posiada największe i najbogatsze obszary wszelkich bogactw naturalnych ${ }^{21}$.

Szybki rozwój państw azjatyckich skutkuje coraz agresywniejszymi poczynaniami korporacji amerykańskich, dotychczas dominujących w świecie, a zwłaszcza w tym regionie Pacyfiku. Czując się zagrożonymi w swoich interesach, sukcesywnie wypierane przez syndykaty azjatyckie, stają się między innymi inspiratorami najrozmaitszych nowych koncepcji politologicznych, antropologicznych czy historiozoficznych, jak chociażby wspomniane powyżej ${ }^{22}$.

19 BRICS, to grupa państw współpracujących ze sobą: Brazylia, Rosja, Indie, Chiny i Republika Południowej Afryki. Nazwa pochodzi od pierwszych liter nazw tych państw.

20 Por. W. Laqueur, Ostatnie dni Europy - epitafium dla Starego Kontynentu, Wrocław 2008.

21 K. Mroziewicz, Duzi chcq być jeszcze więksi, https://www.polityka. pl/tygodnikpolityka/swiat/302305,1,swiatowa-potega-czyli-bric---brazylia-rosja-indie-i-chiny.read [dostęp: 6.01.2020].

22 Ibidem. 
Agresja USA w Iraku, rozpoczęta w styczniu 1991 r., w sposób nader wymowny ukazała dominującą, agresywną rolę Waszyngtonu w świecie oraz przewagę technologiczną armii amerykańskiej. Wojna w Zatoce Perskiej została w Pekinie oceniona jako groźny precedens, wskazywała na możliwość interweniowania USA w każdym regionie świata. Dla Chińczyków był to sygnał pilnej potrzeby modernizacja własnej armii ${ }^{23}$. Atak na USA 11 września 2001 r. przyniósł kolejny zwrot we wzajemnych stosunkach. Choć początkowo Chiny udzieliły poparcia Stanom Zjednoczonym, później zaczęto dostrzegać zagrożenie w postaci wzmocnienia amerykańskiej pozycji w Azji, przede wszystkim poprzez zwiększenie pomocy dla państw sąsiadujących z Chinami, jak Japonia, Filipiny czy państwa Azji Środkowej, co stwarzało sytuację jakby otaczania Państwa Środka ${ }^{24}$. Jednocześnie Waszyngton kontynuował politykę wsparcia Republiki Chińskiej na Tajwanie, wykorzystując ją jako przeciwwagę dla wzrostu znaczenia Chin w regionie, co z kolei Pekin traktuje jako przejaw ingerencji USA w wewnętrzne sprawy Chin ${ }^{25}$.

Stosunkowo mało uwagi poświęca się u nas sprawom Szanghajskiej Organizacji Współpracy, która póki co pozostając paktem politycznym, w najbliższym czasie może przekształcić się w pakt polityczno-wojskowy dysponujący największym w świecie potencjałem militarnym, a przede wszystkim niespotykaną na Zachodzie skutecznością działania. SOW została powołana

23 D. Mierzejewski, Kilka uwag o wspótpracy CHRL i USA: próba bilansu ostatnich trzech dekad, „Azja-Pacyfik” 2002, t. V, s. 184.

24 Szerzej patrz: J. Rowiński, Chiny wobec wydarzeń 11 września 2001 r., [w:] Chiny. Rozwój społeczeństwa i państwa na przełomie XX i XXI wieku, red. K. Tomala, K. Gawlikowski, Warszawa 2002, s. 146-148.

25 Y. Jiemian, Challenges for Sino-U.S. relations: issues and problems, [w:] Asian perspectives on the challenges of China, Papers from the Asia-Pacific Symposium, March 7 and 8, 2000, cosponsored by the National Defense University and U.S. Pacific Command, Washington D.C. 2001, s. 69-70. 
15 czerwca 2001 r. przez Rosję, Chińską Republikę Ludową, Kazachstan, Kirgistan i Tadżykistan. W 2001 r. dołączył do niej Uzbekistan, natomiast w 2017 r. do organizacji wstąpiły Indie i Pakistan. Jej celem jest umacnianie bezpieczeństwa regionalnego w Azji poprzez wielopłaszczyznową współpracę, dodajmy - efektywną.

Szanghajska Organizacja Współpracy wspiera globalną wojnę $\mathrm{z}$ terroryzmem. Ma to duże znaczenie, zważywszy na istniejące napięcia etniczne w Azji Centralnej, mogące doprowadzić do sporów między poszczególnymi państwami regionu i wewnątrz nich, które w szybkim czasie mogłyby się przerodzić w szerszy konflikt i zdestabilizować sytuację w tej części świata.

Do walki z "trzema złami” - terroryzmem, separatyzmem i ekstremizmem, w ramach SOW utworzono Regionalną Strukturę Antyterrorystyczną (RSA). Oprócz RSA w ramach SOW funkcjonuje jeszcze jedna instytucja zajmująca się bezpieczeństwem regionalnym. Jest nią tzw. Grupa Biszkecka, składająca się z szefów organów ochrony porządku prawnego i służb specjalnych państw członkowskich. Jest to organ o charakterze konsultacyjnym - prowadzi dyskusje i przygotowuje plany kooperacji państw w dziedzinie walki z zorganizowanymi grupami przestępczymi, terroryzmem, nielegalną migracją itp. ${ }^{26}$

Na równi ze sprawami bezpieczeństwa, na rozwój organizacji mają wpływ kwestie gospodarcze. Przede wszystkim w ramach SOW rozważa się realizację wspólnych projektów w dziedzinie energetyki, a zwłaszcza tranzytu surowców energetycznych, w szczególności gazu. Plany te budzą zainteresowanie nie tylko członków organizacji, ale również państw mających pozycję ob-

26 Шанхайская организация сотрудничества (справочная информация), www.mid.ru, s. 2; Press-relase on the meeting of the representatives of law-enforcement agencies of the Republic of Kazakhstan, People's Republic of China, Russian Federation, Kyrgyz Republic and The Republic of Tajikistan members of the "Bishkek group" of the Shanghai Organization of Co-operation (May 23, 2002, Astana), www.mfa.kz [dostęp: 12.01.2020]. 
serwatorów: Iranu, Mongolii, wreszcie uczestniczącego w pracach SOW Afganistanu.

Szanghajska Organizacja Współpracy wyrosła na gruncie rozmów o uregulowaniu spraw granicznych i o problemach bezpieczeństwa w regionie. Powstanie SOW skutkuje zwiększeniem kontroli nad migracją w regionie Azji Centralnej, a także ograniczeniem przepływu broni i wszelkiego rodzaju sprzętu oraz materiałów mogących służyć terrorystom. Uszczelnienie granic przyczyniło się w dużym stopniu do zmniejszenia przemytu narkotyków, co ma bezpośrednie przełożenie na ograniczenie środków finansowania organizacji terrorystycznych. Ponadto nie bez znaczenia jest fakt, że forma i cele współpracy zaproponowane przez Rosję i Chiny wpłynęły korzystnie na zredukowanie napięć wynikających z wieloetniczności regionu. Wszak jego mieszkańcy są mocniej związani relacjami lokalnymi, plemiennymi i etnicznymi niż posiadaniem obywatelstwa poszczególnych państw ${ }^{27}$. Korzyści płynące ze współpracy w ramach SOW stały się czynnikami jednoczącymi tę organizację, której znaczenie na scenie międzynarodowej systematycznie rośnie.

Zatem SOW trudno odmówić istotnych osiągnięć o znaczeniu regionalnym. Ale jest również rzeczą bezsporną, że w nieodległej przyszłości SOW może stanowić, o ile już nie stanowi, przeciwwagę dla wpływów Zachodu (przede wszystkim USA) w regionie Azji. Wiele rządów i społeczeństw uważa współczesny imperializm amerykański za istotne zagrożenie dla światowego pokoju. Dla Rosji, Chińskiej Republiki Ludowej, Iranu i co najmniej kilku jeszcze państw azjatyckich, Stany Zjednoczone były i pozostają głównym wrogiem ideologicznym, politycznym i gospodarczym. Nie tylko te państwa czują się zagrożone pro-

27 J.K. Davies, M.J. Sweeney, Central Asia in U.S. Strategy and Operational Planning: Where do we go from here?, Washington 2004, s. 22. 
wadzoną przez USA globalną rozgrywką polityczno-militarną. To wspólne zagrożenie przyczyniło się do zawarcia, z inicjatywy Chin i Rosji, sojuszu, który odgrywa coraz istotniejszą rolę w układzie polityczno-ekonomicznym świata. Jest to również świadectwo umacniania się linii postępowania części państw, wyrażającej się niechęcią wobec ekspansji politycznej i ideologicznej Zachodu, a zwłaszcza Stanów Zjednoczonych.

W odróżnieniu od filozoficzno-doktrynalnych założeń polityki Stanów Zjednoczonych, działalność SOW oparto na filozofii poszanowania różnych kultur, religii, tradycji, pozwalającej na otwartą współpracę międzynarodową. SOW bazuje na dążeniu do syntezy elementów różnych cywilizacji i wartości, jest organizacją łączącą państwa funkcjonujące w różnych cywilizacjach: prawosławno-rosyjskiej, konfucjanistyczno-buddyjskiej, hinduistycznej i islamskiej. Pomimo antyamerykańskiej retoryki SOW nie jest paktem skierowanym przeciwko cywilizacji zachodnioeuropejskiej, a w sensie militarnym przeciwko NATO. Stanowi natomiast bazę współpracy państw, których łączny potencjał pozwala przeciwstawić się jednokierunkowemu narzucaniu woli politycznej przez USA i ich wasali, w myśl której jedynie słusznym dla świata systemem politycznym jest demokracja zachodnioeuropejska, zaś rozwiązaniem ekonomicznym neoliberalna gospodarka rynkowa.

Dawniej praktyki związane z okultyzmem, a obecnie moda na orientalizm stanowią główne przyczyny zainteresowania Tybetem. Współcześnie żywa jest idea obrony kraju przed rzekomo niesprawiedliwymi rządami ChRL. Jest ona akceptowana w pewnych kręgach intelektualnych i młodzieżowych pod hasłem obrony praw człowieka lub prawa do suwerenności. Często solidarność $\mathrm{z}$ Tybetem jest utożsamiana z demonstrowaniem niechęci do Chin ${ }^{28}$.

28 S. Szynkiewicz, Mit i wspótczesne realia Tybetu. Wybrane problemy społeczno-polityczne, „Azja-Pacyfik” 2004, t. VII, s. 60. 
Mit stworzony wokół Tybetu spowodował, że powstał międzynarodowy ruch skierowany przeciw ponoć niewolniczemu uzależnieniu, prześladowaniu religii i niszczeniu kultury tybetańskiej. Międzynarodowa Akcja na rzecz Tybetu (International Campaign for Tibet) kieruje swoją aktywność głównie do ludzi niezbyt zorientowanych w rzeczywistej sytuacji Tybetu, którzy operują na ogół stereotypami i propagandowymi frazesami. Sprzyja temu panujący w kręgach emigracyjnych Tybetańczyków, wynikający z potrzeb walki politycznej, zwyczaj totalnego negowania i dyskredytowania wszelkich pozytywnych zmian w Tybecie ${ }^{29}$.

Tybet pozostaje $\mathrm{w}$ dalszym ciągu sceną sporadycznych niepokojów społecznych, jednak na zdecydowanie mniejszą już skalę niż miało to miejsce w przeszłości. Warunki życia uległy tam poprawie, przywrócono część swobód religijnych, ukazuje się prasa i literatura w miejscowym języku. Faktem jest, że te przemiany nie usunęły jeszcze wszystkich zagrożeń dla tożsamości kulturowej ${ }^{30}$. Ludność Tybetu pozostaje w zasadzie politycznie bierna, zainteresowana przede wszystkim kwestiami bytowymi i możliwościami rozwijania przedsiębiorczości. Niepokoje wzniecają na ogół ludzie młodzi, w większości mnisi, podejrzewani o uleganie inspiracjom płynącym z zewnątrz, demonstrujący przy różnych okazjach przeciwko chińskiej obecności żądający bliżej nieokreślonych swobód i przywilejów. Przy czym należy podkreślić, że wolności religijne choć znaczne, ale jeszcze niepełne ${ }^{31}$.

Sukcesy Azji znajdują swoje odzwierciedlenie w polityce państw azjatyckich, która jest kreatorem współczesnych stosunków międzynarodowych i instrumentem hierarchizacji

\footnotetext{
29 Ibidem, s. 67.

30 Ibidem, s. 94.

31 Ibidem, s. 96.
} 
krajów i kontynentów. Wzajemne relacje między gospodarką a polityką przekładają się na procesy transformacji dzisiejszego świata. Rzecz dotyczy nie tylko wymiaru ekonomicznego, czyli rosnącej roli państw azjatyckich w światowych procesach gospodarczych, ale także transformacji globalnej polityki ${ }^{32}$. Aktualne pytanie brzmi: dlaczego to właśnie Azja ma być nowym centrum świata? Sądzić należy, że nie do końca mają rację zachodni politolodzy i ekonomiści, którzy zwracają uwagę na stopniowe przeobrażanie się tradycyjnej azjatyckiej kultury wspólnotowej w kulturę indywidualistyczną. Z kolei przedstawiciele państw azjatyckich podkreślają ogromne znaczenie pierwiastka wspólnotowego w procesie dynamicznego rozwoju tej części świata. Co prawda indywidualizm sprzyja kreatywności i współzawodnictwu, co widać na przykładzie USA i Europy Zachodniej, lecz siła Azji tkwi w myśleniu wspólnotowym, które pozwala na zdecydowanie większą wydajność i skuteczność. Na poparcie tezy o wyższości kultury wspólnotowej nad indywidualizmem niech świadczy fakt, że biorąc przykład ze społeczeństw azjatyckich, w amerykańskich, a ostatnio również w zachodnioeuropejskich szkołach i uniwersytetach uczy się i wymaga w praktyce umiejętności kolektywnego rozwiązywania wszelkich problemów w otaczającej rzeczywistości. W sferze polityki narzędziem skutecznie integrującym społeczeństwa azjatyckie w dążeniu do realizacji wytyczonych celów jest ich współczesna mitologia polityczna.

32 P. Kłodkowski, A. Siewierska-Chmaj, Nowe centrum świata?, „Znak” 2009, nr 646, s. 20. 


\section{Bibliografia}

\section{Monografie i druki zwarte}

Armstrong K., Krótka historia mitu, Kraków 2005.

Baczwarow M., Suliborski A., Kompendium wiedzy o geografii politycznej i geopolityce, Warszawa 2003.

Biernat T., Mit polityczny, Warszawa 1989.

Davies J., Sweeney M., Central Asia in U.S. Strategy and Operational Planning: Where do we go from here?, Washington 2004.

Eliade M., Sacrum. Mit. Historia, Warszawa 1993.

Filipowicz S., Mit i spektakl władzy, Warszawa 1988.

Fukuyama F., The end of history and the last man, New York 1992, (wyd. pol., Koniec historii i ostatni człowiek, Kraków 2017).

Gawlikowski K., Dwie cywilizacje i ich wizje człowieka: Zachód i Azja Wschodnia, Warszawa 1997.

Gawlikowski K., Perspektywy demokratycznych przemian w Chinach, [w:] Chiny w XXI wieku. Perspektywy rozwoju, red. W. Dziak, K. Gawlikowski, M. Ławacz, Warszawa 2012.

Guéhenno Je.-M., La fin de la democratie, Paris 1993 (wyd. ang. The end of the nation-state, Minnesota 2000, wyd. pol. Przyszłość wolności: demokracja w globalizacji, Kraków 2001).

Huntington S., Zderzenie cywilizacji i nowy kształt ładu światowego, Warszawa 1997.

Jabłoński W., Religie Chin, [w:] Trzaska, Evert i Michalski, Religie Wschodu, pr. zb., Warszawa 1938.

Jiemian Y., Challenges for Sino-U.S. relations: issues and problems, [w:] Asian perspectives on the challenges of China, Papers from the Asia-Pacifi c Symposium, March 7 and 8, 2000, cosponsored by the National Defense University and U.S. Pacific Command, Washington D.C. 2001. 
Kłodkowski P., Siewierska-Chmaj A., Nowe centrum świata?, „Znak” 2009, nr 646.

Laqueur W., Ostatnie dni Europy - epitafium dla Starego Kontynentu, Wrocław 2008.

Rowiński J., Chiny wobec wydarzeń 11 września 2001 r., [w:] Chiny. Rozwój społeczeństwa i państwa na przełomie XX $i$ XXI wieku, red. K. Tomala, K. Gawlikowski, Warszawa 2002.

Spengler O., Zmierzch Zachodu. Zarys morfologii historii uniwersalnej, Warszawa 2001.

Szczurowski M., Mity, symbole, rytuaty a żotnierz polski w przestrzeni politycznej II wojny światowej, Toruń 2013.

\section{Artykuły w czasopismach}

Justyński J., Społeczeństwo i państwo w ideologii „indyjskiego renesansu, „Czasopismo Prawno-Historyczne” 1973, t. XXV, z. 2.

Mierzejewski D., Kilka uwag o wspótpracy CHRL i USA: próba bilansu ostatnich trzech dekad, „Azja-Pacyfik” 2002, t. V.

Szynkiewicz S., Mit $i$ wspótczesne realia Tybetu. Wybrane problemy społeczno-polityczne, „Azja-Pacyfik” 2004, t. VII.

\section{Źródła internetowe}

Mroziewicz K., Duzi chcą być jeszcze więksi, https://www.polityka.pl/tygodnikpolityka/swiat/302305,1,swiatowa-potega-czyli-bric---brazylia-rosja-indie-i-chiny.read.

Press-relase on the meeting of the representatives of law-enforcement agencies of the Republic of Kazakhstan, People's Republic of China, Russian Federation, Kyrgyz Republic and The Republic of Tajikistan - members of the "Bishkek group" of the Shanghai Organization of Co-operation (May 23, 2002, Astana), www.mfa.kz.

Шанхайская организация сотрудничества (справочная информация), www.mid.ru. 


\begin{abstract}
Abstrakt
Sferę duchową społeczeństw dopełniają mity. Mit polityczny jest swoistą formą idei politycznej. Z uwagi na ogromną różnorodność kulturowo-polityczną kontynent azjatycki pozostaje w kręgu szczególnego zainteresowania zagadnieniami dotyczącymi charakteru i roli, jaką mają do spełnienia w praktyce mity polityczne. Podejmowanie prób analizy tych zagadnień zapewne będzie skutkować lepszym zrozumieniem kierunków polityki formułowanych przez społeczeństwa i przywódców tego największego z kontynentów.

Sukcesy Azji znajdują swoje odzwierciedlenie w polityce państw azjatyckich, która jest kreatorem współczesnych stosunków międzynarodowych i instrumentem hierarchizacji państw i kontynentów. W sferze polityki narzędziem skutecznie integrującym społeczeństwa azjatyckie w dążeniu do realizacji wytyczonych celów jest ich współczesna mitologia polityczna.
\end{abstract}

Słowa kluczowe: mit polityczny, Azja, Chiny, kultura polityczna

\begin{abstract}
The spiritual sphere of societies is complemented by myths. Political myth is a specific form of political idea. Due to the huge cultural and political diversity, the Asian continent remains in the circle of particular interest in issues related to the nature and role that political myths have in practice. Attempting to analyze these issues will probably result in a better understanding of policy directions formulated by the societies and leaders of this largest continent.

Asia's successes are reflected in the policy of Asian countries, which is the creator of contemporary international relations and an instrument for the hierarchy of countries and continents. In the sphere of politics, modern political mythology is a tool that effectively integrates Asian societies in pursuit of their goals.
\end{abstract}

Keywords: political myth, Asia, China, political culture 


\section{Patryk Piotr Madej}

Uniwersytet Szczeciński

\section{Separatyzm cypryjski - wielowymiarowość problemu}

\section{Wstęp}

Decyzje obu narodów dotyczące walki o swoje racje wpłynęły znaczącą na kształt dzisiejszej Republiki Cypryjskiej, układu sił w regionie wschodniego morza Śródziemnego. Pośrednio sytuacja ta ma także wpływ na relacje międzynarodowe tego państwa, a także Republiki Greckiej i Tureckiej. Biorąc pod uwagę liczne w Europie tendencje separatystyczne oraz ich charakterystykę stwierdzić można, że separatyzm cypryjski jest wyjątkowy ze względu na sytuację stron sporu oraz rozwój struktury państwa. Republika Cypryjska jest państwem położonym w zachodniej Azji. Znajduje się ona na wyspie o takiej samej nazwie we wschodniej części Morza Śródziemnego. Od 16 sierpnia 1960 r. jest niepodległym państwem ${ }^{1}$. Do tego czasu, od 1878 r., rządzona była przez Wielką Brytanię, na mocy firmanu podpisanego przez sułtana oddającego wyspę we władanie królestwa² ${ }^{2}$ Zgodnie z danymi 2011 r., opublikowanymi na zlecenie cypryjskiego rządu z Nikozji, 71,8\% obywateli stanowią Grecy cypryjscy,

A. Ambroziak, Aspiracje integracyjne państw śródziemnomorskich Cypr, „Wspólnoty Europejskie” 1995, nr 4, s. 8.

2 K. Kuczowicz, Funkcjonowanie quasi-państwa w zjednoczonej Europie. Cypr Północny, „Res Politicae. Prace Naukowe Akademii im. Jana Długosza w Częstochowie" 2013, t. V, s. 76. 
a 9,5\% Turkowie cypryjscy ${ }^{3}$. W większości dostępnych jednak źródeł dane te przypominają bardziej te znane już od 2001 r., które nadal są aktualne i wskazują, że ludność pochodzenia tureckiego liczy około 18\%4. Taka struktura społeczeństwa wprowadziła bardzo dużą trudność w zakresie zarządzania państwem.

Od samego początku istnienia Republiki zauważalne były liczne problemy w zakresie ustawodawstwa. Niemożliwe było uchwalenie między innymi podstawowych ustaw, takich jak budżetowej, podatkowej czy samorządowej ${ }^{5}$. Wynikało to z uwarunkowań prawnych ustroju oraz nastawieniu obu stron, które rozpoczęły między sobą "polityczną walkę"6. Podstawowymi elementami Konstytucji Cypru było ustanowienie na jej czele greckiego prezydenta oraz tureckiego wiceprezydenta. Ten drugi został wyposażony w prawo weta wobec decyzji rządu, co uniemożliwiło greckiej większości wprowadzenia jakichkolwiek postanowień bez zgody mniejszości tureckiej. Warto ponadto zwrócić uwagę na skład ilościowy armii cypryjskiej, która według założeń miała się składać z 60\% z Greków i 40\% z Turków. Biorąc pod uwagę faktyczną różnicę w ludności tego państwa (stosunek 70\% do 20\%) zauważyć można, że mniejszość zamieszkująca wyspę została wyposażona w większą ilość przywilejów niż mogłoby to wydawać się zasadne ${ }^{7}$.

3 Cyprus in Figures. 2013 edition, Report Np. 18, Press and Information Office for the Statistical Service, http://www.cystat.gov.cy/mof/cystat/statistics.nsf/All/E3D6660151C37B35C2257DBD0034C3C3/\$file/CYPRUS_IN_ FIGURES-2013-EN-070114.pdf?OpenElement [dostęp: 26.01.2020].

4 Zob. C. Theodoulou, The Cyprus Question: Some Facts, Ateny 1975, s. 8; K. Czubocha, M. Paszkowska, Konflikt cypryjski i jego wptyw na proces rozszerzenia Unii Europejskiej, „Zeszyty Naukowe Zakładu Europeistyki Wyższej Szkoły Informatyki i Zarządzania w Rzeszowie” 2007, nr 1 (3), s. 31; Cyprus Population 2020, World Population Review, http://worldpopulationreview.com/countries/cyprus-population/ [dostęp: 26.01.2020].

5 A. Adamczyk, Problem cypryjski, „Studia Europejskie” 1997, nr 4, s. 75.

6 K. Kuczowicz, op.cit., s. 78.

7 Zob. K. Czubocha, M. Paszkowska, op.cit., s. 31; K. Kuczowicz, op. cit., s. 78. 
Nieproporcjonalne kompetencje Turków cypryjskich spowodowały niezadowolenie wśród ich współobywateli, co doprowadziło do próby przeforsowania zmian w konstytucji polegających głównie na umniejszeniu wspomnianych praw - powstał wówczas projekt nowelizujący konstytucję, nazywany często „13 punktami Makariosa”. Jego celem było uzdrowienie sytuacji politycznej, a także uniknięcie eskalacji konfliktu na wyspie9 W skutek działania posłów greckich w parlamencie doszło do starć zbrojnych między stronami, który wymagał ingerencji środowiska międzynarodowych. W 1964 r., na mocy rezolucji Rady Bezpieczeństwa Organizacja Narodów Zjednoczonych (dalej jako ONZ) nr $186 \mathrm{w}$ sprawie Cypru, ONZ postanowiła wysłać na Cypr siły pokojowe (United Nations Peacekeeping Force in Cyprus, dalej jako UNFICYP), co nie przyniosło jednak zamierzonych rezultatów, a konflikt rozwijał się dalej nie tylko na wyspie, ale także między samą Turcją i Grecją. Dalsze negocjacje nie prowadziły jednak do rozwiązania sporu, a działalność greckiego rządu Cypru doprowadził do zbrojnej reakcji Turcji. W rezultacie 13 lutego $1975 \mathrm{r}$. miała miejsce proklamacja niepodległości przez Turecką Republikę Cypru Północnego (dalej jako TRCP) ${ }^{10}$. W związku z tym wyspa została podzielona na dwie części, a podział ten trwa do dzisiaj.

Celem artykułu jest wyjaśnienie konsekwencji obecnego na terenie Republiki Cypryjskiego separatyzmu. Autor w tym miejscu stawia tezę, że głównym czynnikiem powodującym pojawienie się, a także wzrost tendencji separatystycznych na wyspie są

8 K. Kuczowicz, op.cit., s. 78.

9 M. Raczyńska, Przebieg i skutki konfliktu cypryjskiego, „Zeszyty Naukowe Koła Studentów Stosunków Międzynarodowych Uniwersytetu Jagiellońskiego" 2013, nr 1 (4), s. 89.

10 H. Faustmann, Aktualne ogniska konfliktu. Konflikt na Cyprze odzwierciedleniem różnicy interesów we wschodniej części Morza Śródziemnego, Eduvinet.de, http://www.eduvinet.de/comcult/pdf/regiokonf/pl/cocpltla404. pdf [dostęp: 26.01.2020]. 
działania państw trzecich. W swojej konsekwencji natomiast aktualny stan faktyczny wpływa w sposób negatywny na sytuację terenów wchodzących w skład TRCP. Autor poświęca również uwagę niezależności obu stron w swoim funkcjonowaniu oraz następstw zbyt dużego uzależnienia się od większych podmiotów na arenie międzynarodowej. W artykule poruszona zostanie nie tylko kwestia separatyzmu pod względem jej charakterystyki, ale także poprzez pryzmat ambicji narodów współczesnej Europy. Nakreślona zostanie również sytuacja ekonomiczna regionu wraz z potencjałem rozwoju gospodarczego, w tym turystycznego wyspy z perspektywy istniejącego sporu.

\section{Idea Wielkiego Państwa a Cypr}

Idea Wielkiego Państwa, zwana także czasem ideą wielkiego narodu, jest jednym z przykładów nacjonalistycznych dążeń państw już od wieków. Przykładami tego typu działań są między innymi grecka megali idea, idea Wielkiej Serbii, Wielkiej Chorwacji, Wielkiej Albanii ${ }^{11}$. Cypr stał się również elementem polityki obu stron sporu w zakresie powiększenia swojego terytorium i zwiększenia swoich wpływów w obrzeżach Morza Śródziemnego.

Greckim przejawem ambicji utworzenia Wielkiej Grecji był ruch nazywany „Enosis” (z greckiego zjednoczenie). Dążył on do całkowitego wyzwolenia Cypru oraz dołączenia go do samej Grecji. Warto tutaj zauważyć, że idea ta powstała już na początku

11 Zob. H. Ciszek, Wielka idea a budowanie jedności i tożsamości narodowej Greków, „Porównania” 2009, nr 6, s. 245-247; T. Czekalski, Problem Kosowa na tle stosunków albańsko-jugosłowiańskich w latach 1944-1948, „Zeszyty Naukowe Uniwersytetu Jagiellońskiego” 2011, r. MCCCXVIII, s. 177; W. Paruch, Między polityzacją etnosu a etnicyzacją demosu: refleksje o polityce narodowej na Batkanach, „Annales Universitatis Mariae Curie-Skłodowska Lublin - Polonia" 2016, vol. I, s. 70-71. 
XX w. i wymierzona była w Wielką Brytanię ${ }^{12}$. Ugrupowaniem, które w szczególny sposób dążyło do realizacji wspomnianego celu była Narodowa Organizacja Walki o Niepodległość Cypru EOKA, zwana także Narodową Organizacją Cypryjskich Bojowników. Powstała ona w 1955 r. na skutek nieuznania przez władze brytyjskie plebiscytu na wyspie, w którym większość mieszkańców opowiedziała się za przyłączeniem wyspy do Grecji. Po proklamacji niepodległości Republiki Cypryjskiej, na skutek toczącego się między stronami konfliktu, część byłych członków wspomnianej organizacji stanęła na czele Frontu Narodowego dzielącego ideę przyłączenia. W związku z silną działalnością EOKA w ostateczności doszło do ingerencji sił tureckich, o której już wspomniano. Ostatecznie, że nie udało się wdrożyć tego planu. Warto tutaj podkreślić, że samo enosis nie było ruchem powiązanym bezpośrednio tylko z Cyprem, ale również w innych sytuacjach dotyczących zwiększenia terytorium greckiego, jak na przykład w związku z dążeniami o przyłączenie Krety ${ }^{13}$.

Tureckie dążenia w stosunku do terytorium Cypru były o wiele mniej roszczeniowe. W oparciu o ideę taksim (z tureckiego podział) wyspa miała zostać podzielona między państwa sporu zgodnie z faktycznym zamieszkaniem dwóch skłóconych narodów. Powstała ona w podobnym czasie jak enosis i również była pierwotnie skierowana przeciwko Wielkiej Brytanii. Po uznaniu niepodległości Republiki Cypryjskiej idea taksim była nadal żywa w związku z dążeniami Greków cypryjskich, którzy dążyli do zmniejszenia kompetencji mniejszości tureckiej. Kluczowym momentem w tym zakresie była inwazja turecka, stanowiąca odpowiedź na zwiększenie się działalności progreckiej bojówki. Warto zauważyć, że sam pogląd na rozwiązanie

12 K. Czubocha, M. Paszkowska, op.cit., s. 33-34.

13 G.K. Dalidakis, Enosis, The Union of Crete with Greece, Dalidakis, https://web.archive.org/web/20120425132526/http://www.dalidakis.com/ Enosis the Union of Crete with Greece in 1913.pdf [dostęp: 26.01.2020]. 
cypryjskiego sporu powstał dzięki inicjatywie Lennox Boyda, który był ministrem do spraw kolonii Wielkiej Brytanii ${ }^{14}$.

Zauważyć zatem można, że idea wielkiego państwa również miała być realizowana (w mniejszym lub większym stopniu) przez Grecję oraz Turcję poprzez walkę o terytorium Republiki Cypryjskiej. W konsekwencji idea taksim została w części zrealizowana, aczkolwiek nie w oczach środowiska międzynarodowego.

\section{Uznawalność Tureckiej Republiki Cypru Północnego}

Mimo proklamowania niepodległości przez Turecką Republikę Cypru Północnego w 1975 r. państwo to nadal w oczach środowiska międzynarodowego nie istnieje. Jedynie Republika Turcji uznała to państwo, co wydaje się zasadne w oparciu o inwazję, do której się dopuściła na terenie Cypru. Wspomniana ingerencja, uznana za podbój, naruszyła postanowienia prawa międzynarodowego publicznego, według których niemożliwe jest w jej konsekwencji utworzenie państwa. Rada Bezpieczeństwa ONZ w rezolucjach nr 541 i 550 wskazała zatem, że secesja ta została wykonana z naruszeniem norm prawa międzynarodowego i nakazała nieuznanie tego państwa na arenie międzynarodowej. W związku z brakiem utrzymywania jakichkolwiek relacji międzypaństwowych (poza stosunkami z Turcją) TRCP nie spełnia czwartego kryterium definiującego państwa, czyli możliwości wchodzenia w stosunki z innymi podmiotami międzynarodowymi, które na mocy międzyamerykańskiej Konwencji o prawach i obowiązkach państw z 1933 roku został wprowadzony do praktyki ${ }^{15}$.

14 A. Bernard, Republika Cypru. Kipriaki Dimokratia. Kibris Cumhuriyeti, Warszawa 1976, s. 28-29.

15 P. Osiewicz, Wybory w państwie nieuznawanym na przykładzie Tureckiej Republiki Pótnocnego Cypru, [w:] Czy upadek demokracji? Wymiar praktyczny, red. A. Stelmach, Poznań 2007, s. 61-63. 
W oczach państw współczesnego państwa TRCP nie istnieje, a stanowi jedynie część Republiki Cypryjskiej. Zostało to wielokrotnie potwierdzone przez nie tylko władze poszczególnych krajów, ale również przez wiele organizacji międzynarodowych, których to państwem członkowskim jest wspomniana republika. Organizacja Narodów Zjednoczonych, której jest częścią od 1960 r. zarówno nie uznała TRCP, jak również nie podejmowała tematu zmiany granic z władzami z Nikozji. Jest ona również członkiem Rady Europy, Organizacji Wspólnoty Narodów, Międzynarodowego Funduszu Walutowego. Od 2004 r. Cypr jest także państwem członkowskim Unii Europejskiej, aczkolwiek status północnej części wyspy we wspólnocie jest zawieszony w związku z brakiem pełnej kontroli przez rząd w Nikozji nad tym terenem.

Jedynym państwem, które nie uznaje Republiki Cypryjskiej jest Turcja, co jest w pełni zasadne w związku z uznaniem przez rząd w Ankarze TRCP. Cała polityka Republiki Turcji znalazła swoją odpowiedź w braku chęci Unii Europejskiej do przyjęcia jej w strukturę państw członkowskich ${ }^{16}$.

Niezbędne jednak w tym miejscu jest zwrócenie uwagi, że nieuznanie TRCP nie jest jednoznacznym fiaskiem po stronie Turków cypryjskich. Ostatecznie uznana ona została przez inne nieuznawane państwa, takie jak Nachiczewańską Republikę Autonomiczną czy Czeczenię. Otrzymała ona również status obserwatora w Organizacji Współpracy Islamskiej (na początku jako „tureccy muzułmanie z Cypru”, a dopiero w 2004 r. jako TRCP ${ }^{17}$. Ponadto w 2004 r. przedstawiciele wspólnoty Turków cypryjskich (nie jako reprezentanci TRCP) otrzymali

16 A. Adamczyk, Proces integracji Republiki Cypru ze Wspólnotami Europejskimi i jego ewentualny wplyw na rozwiazanie problemu cypryjskiego, „Studia Europejskie” 1999, nr 4, s. 117.

17 M. Śmigasiewicz, Uwarunkowania geopolityczne państw nieuznawanych - casus Tureckiej Republiki Cypru Pótnocnego, „Przegląd Geopolityczny" 2014, t. 9, s. 191. 
status obserwatorów w Zgromadzeniu Parlamentarnym Rady Europy.

\section{Charakterystyka separatyzmu cypryjskiego}

W przypadku Republiki Cypryjskiej możliwe jest zidentyfikowanie dwóch oddzielnych tendencji separatystycznych. Jeden z nich dotyczy chęci odłączenia tureckiej części, a drugi przyłączenia całego państwa do Grecji. Warto tutaj zauważyć, że istnienie któregokolwiek z nich napędza działalność drugiego. Jedyną ideą, która nie wskazuje na owe ruchy jest utrzymanie status quo republiki. Sytuacja ta, na przestrzeni współczesnych separatyzmów, jest wyjątkowa.

Niezbędne jest podkreślenie, że pierwotny „kształt” Republiki Cypryjskiej w oparciu o jej konstytucję wskazywał na wprowadzenie elementów modelu demokracji konsensualnej, którego zastosowanie w przypadku tego typu struktury ludności opracował Arend Lijphart ${ }^{18}$. Schemat ten miałby teoretycznie duże szanse powodzenia, czego dowodem jest stabilność wielu państw o wielonarodowej strukturze. Wspomniane postanowienia jednak nie zostały utrzymane, co wpłynęło na eskalację konfliktu.

Warto podkreślić, że szczególną cechą charakteru separatyzmów występujących w Republice Cypru jest silne ukierunkowanie na dokonanie secesji faktycznej. W przypadku mniejszości tureckiej zagwarantowane im prawa na początku istnienia państwa nie zaspokoiły ich żądań, co wyrażane było w utrudnieniu funkcjonowania państwa. Większość grecka, mimo silnej pozycji w państwie chciała ją umacniać coraz bardziej. W ostateczności obie strony długi czas dążyły do wydzielenia swojej części

18 A. Jelonek, Dylematy konsocjonalizmu: przypadek Malezji, Warszawa 2004, s. 15-16. 
terytorialnej i przyłączeniu jej do państwa „swojego pochodzenia". Warto tutaj zwrócić uwagę, że próba utworzenia regionu autonomicznego nie było między stronami brane pod uwagę. Stwierdzić zatem można, że oba narody dążyły do odłączenia się do Republiki Cypryjskiej, co byłoby jednoznaczne ze zniknięciem tego państwa z mapy świata. Ostatecznie separatyzm grecki został wyciszony na mocy działalności Unii Europejskiej i zmniejszonych roszczeń samej Grecji. Tendencje mniejszości tureckiej nadal są silnie zauważalne, czego dowodem jest podkreślanie swojej odrębności w ich życiu codziennym.

\section{Ekonomiczne skutki separatyzmu cypryjskiego}

W oparciu o reakcję środowiska międzynarodowego nietrudno jest przewidzieć, że sytuacja gospodarcza TRCP nie jest tak dobra jak Republiki Cypryjskiej. Wynika to przede wszystkim z istnienia wielu obostrzeń proceduralnych dotyczących przywozu towarów pochodzących z północnej części wyspy na terytorium państw Unii Europejskiej ${ }^{19}$. Przyglądając się ilości importowanych towarów przez TRCP w 2010 r. (1 604,2 mln USD) oraz eksportowanych (96,4 mld USD) stwierdzić można, że państwo to opiera się głównie na imporcie dóbr. Biorąc również pod uwagę, że mniej więcej $70 \%$ dóbr importowanych pochodzi z Turcji, zauważyć można silne od niej uzależnienie gospodarcze TRCP. Około połowa dóbr eksportowanych za granicę trafia właśnie do sąsiadów z półwyspu Azji Mniejszej, pozostała część do państw Bliskiego Wschodu. Produktami, które stanowią główną część towarów przeznaczonych na sprzedaż zagranicą, są cytrusy.

19 Cypr Północny - państwo, które teoretycznie nie istnieje, Forsal.pl, https://forsal.pl/artykuly/813700,cypr-polnocny-panstwo-ktore-teoretycznie-nie-istnieje.html [dostęp: 26.01.2020]. 
Mimo wielu trudności jednak zauważalny jest pewien wzrost gospodarczy tego państwa. Jednym z silnych czynników, które przyczyniły się do niego był silny wzrost sprzedaży i budowy domów, do którego przyczynili się głównie obywatele Wielkiej Brytanii (bardzo często posiadający jakieś powiązania z Cyprem sprzed proklamacji niepodległości przez Republikę Cypryjską) ${ }^{20}$.

Niestabilna sytuacja ekonomiczna państwa, mimo ciągłego rozwoju, ma bezpośredni wpływ na powiększanie się deficytu budżetowego. Jedyną szansą pokrycia go są pożyczki udzielane przez Turcję, których wysokość w oparciu o dane z 2010 r. wynosiły 364 mld USD ${ }^{21}$. Zauważalny jest dalszy trend udzielania przez rząd w Ankarze dalszych pożyczek, co powoduje coraz silniejsze uzależnienie finansowe TRCP. Pomoc państwa tureckiego wobec ich cypryjskich rodaków nie jest bezinteresowna. Wynika ona z dalszej chęci ingerencji w sytuację na wyspie i ma na celu umocnienie aktualnego układu politycznego.

Jedną z szans na wzrost ekonomiczny TRCP jest silne rozwinięcie turystyki w państwie, co też jest planem rządu już lat 90. ubiegłego wieku, czego dowodem są plany rozwoju tworzone przez premiera ${ }^{22}$. Niezbędne jest jednak przyjrzenie się tej kwestii dokładniej z perspektywy licznych trudności związanych z aktualną sytuacją na wyspie.

W przypadku południowej części wyspy sytuacja ma się o wiele lepiej. Republika Cypryjska jest jedną z najszybciej rozwijających się gospodarek Unii Europejskiej, a bezrobocie spada najszybciej spośród wszystkich państw członkowskich

20 V. Yorucu, The construction boom and environmental protection in Northern Cyprus as a consequence of the Annan Plan, "Construction Management and Economics" 2007, nr 25 (1), s. 78-80.

21 M. Śmigasiewicz, op.cit., s. 194.

22 B. Kanol, Sustainable Tourism Development in Northern Cyprus and Prospects for Convergence, 2005, ResearchGate, https://www.researchgate. net/publication/237103626_Sustainable_Tourism_Development_in_Northern_Cyprus_and_Prospects_for_Convergence, s. 9 [dostęp: 26.01.2020]. 
wspólnoty ${ }^{23}$. Eksport produktów wynosi 3,59 mld euro, a import 9,6 mld euro (dane z 2017 r.), co udowadnia dużo większą stabilność tej gospodarki ${ }^{24}$.

\section{Turystyka a separatyzm cypryjski}

Cypr z uwagi na swoje położenie, a także piękne krajobrazy jest jednym ze stałych celów turystycznych Europejczyków. Istnieje jednak znacząca różnica między dwiema częściami wyspy w kwestii rozwoju turystycznego.

W przypadku południowej części Republiki Cypryjskiej zauważalny jest silny rozwój sektora turystycznego w państwie. Z roku na rok na wyspę przybywa coraz więcej odwiedzających, w 2015 r. liczba ta wynosiła 2,65 mln osób, co wpłynęło na wzrost przychodów o 4,4\%. W sumie działalność w tym zakresie przynosi Cypryjczykom 12\% PKB ${ }^{25}$. W oparciu o informacje udostępnione na stronie Ministerstwa Spraw Zagranicznych, w trakcie odwiedzin zalecane jest zachowanie jedynie zwykłej ostrożności. Istotne jest, że do państwa można dostać się tylko przez porty lotnicze i morskie znajdujące się w strefie bezpośrednio podlegającej jurysdykcji władz Republiki. Ze względu na szczególny charakter terenów brytyjskich baz wojskowych, wstęp na te obszary jest zabroniony ${ }^{26}$.

23 Cypr. Informacje o kraju, Informator Ekonomiczny Ministerstwa Spraw Zagranicznych, https://informatorekonomiczny.msz.gov.pl/pl/europa /cypr/ [dostęp: 26.01.2020].

24 Cyprus, OEC, https://oec.world/en/profile/country/cyp/ [dostęp: 26.01.2020].

25 Turyści uciekają przed terroryzmem, Cypr bije rekordy popularności, 18.07.2016, https://tvn24bis.pl/ze-swiata,75/rekordowy-naplyw-turystow-do-cypru,661851.html [dostęp: 26.01.2020].

26 Cypr, Ministerstwo Spraw Zagranicznych, https://www.gov.pl/web/ dyplomacja/cypr [dostęp: 26.01.2020]. 
Sytuacja turystyczna w północnej części TRCP jest o bardziej skomplikowana. W związku z brakiem stosunków dyplomatycznych między TRCP, a większością państw podróże $\mathrm{w}$ tym rejonie są odradzane. Zgodnie $\mathrm{z}$ informacją przekazaną przez polskie Ministerstwo Spraw Zagranicznych nakazane jest zachowanie szczególnej ostrożności. Wynika to z faktu, że w przypadku jakiejkolwiek potrzeby niemożliwe będzie udzielenia pomocy konsularnej (jest to następstwem braku podpisania z TRCP jakiegokolwiek porozumienia regulującego realizację funkcji konsularnych, a także faktu, że nie jest ona stronom Konwencji wiedeńskiej o stosunkach konsularnych z 1963 r.). Podkreślony został również fakt, że żadne z lotnisk znajdujących się na tym terenie nie zostało dopuszczone do międzynarodowego ruchu lotniczego, co nie potwierdza bezpieczeństwa lotów (samoloty żadnego z państw członkowskich UE oraz państw trzecich nie może wylądować na tych lotniskach). Ponadto dostanie się na wyspę poprzez jakikolwiek port znajdujący się w strefie niekontrolowanej przez rząd w Nikozji uznane będzie za nielegalne przekroczenie granic państwa ${ }^{27}$. Sama kwestia turystyki rozwija się, aczkolwiek jest mniej chętnych niż w przypadku południowej części wyspy, co wynika głównie z braku zabezpieczenia w pomoc konsularną oraz trudności w dostaniu się na miejsce wypoczynku z państw europejskich. Zgodnie z danymi z 2013 r. mniej więcej 80\% turystów odwiedzających TRCP pochodzi z Turcji, co stanowi zdecydowaną większość przychodów pochodzących z tego sektora gospodarki ${ }^{28}$.

Sytuacja jest również wyjątkowo skomplikowana dla mieszkańców TRCP. Ich paszporty nie są w żaden sposób respekto-

27 Ibidem.

28 KKTC, turizm rakamlarını 10 yılda 2-3'e katladı, „Dunya”, 26.03.2013, https://www.dunya.com/sektorler/turizm/kktc-turizm-rakamlarini-10-yilda2-3039e-katladi-haberi-205658 [dostęp: 26.01.2020]. 
wane przez wszystkie państwa poza Republiką Turcji. W przypadku chęci udania się do któregokolwiek z państw niezbędne jest ubieganie się przez owe osoby o trzymanie paszportu Republiki Cypryjskiej lub Turcji ${ }^{29}$.

\section{Podsumowanie}

Cypryjscy Grecy i Turkowie, mieszkańcy Cypru, wyspy położonej we wschodniej części Morza Śródziemnego, która od 1878 do 1960 r. znajdowała się we władaniu Wielkiej Brytanii, od XIX w. już ubiegali się o niepodległość. W momencie, w którym została ona proklamowana ich ambicje nadal pozostały żywe. Wiązały się one z chęcią przyłączenia wyspy do Republiki Greckiej albo Republiki Tureckiej. Pod uwagę brano również podział terytorium między zwaśnione strony. Mimo zastosowania elementów modelu konsensualnego demokracji niemożliwe było utrzymanie państwa w pierwotnych strukturach, a nadmierna działalność lokalnych bojówek w swojej konsekwencji doprowadziła do ingerencji militarnej i proklamowania przez północnych separatystów Tureckiej Republiki Cypru Północnego (1975). Decyzja ta wpływa na relacje międzynarodowe w tym rejonie Azji i Europy po dzień dzisiejszy.

Brak uznanie na arenie międzynarodowej TRCP utrudnia w znaczącym stopniu rozwój tego quasi-państwa. Wynika to przede wszystkim z braku jakichkolwiek umów międzypaństwowych regulujących kwestie handlowe czy konsularne. Nałożone na nią embargo zmniejsza liczbę potencjalnych rynków zbytu produktów, co w sposób drastyczny wpływa na sytuację ekonomiczną. Ograniczone są również możliwości rozwoju

29 Cypr Pótnocny - państwo, które teoretycznie nie istnieje, Forsal.pl, https://forsal.pl/artykuly/813700,cypr-polnocny-panstwo-ktore-teoretycznienie-istnieje.html [dostęp: 26.01.2020]. 
turystyki ze względu na mniejsze zainteresowanie turystów z państw europejskich. Jedynym państwem, które uznało istnienie TRCP jest Republika Turcji, która jest zarazem jej głównym sojusznikiem. W związku z prowadzoną współpracą między tymi państwami zapewniana jest ciągłość funkcjonowania TRCP, głównie ze względu na liczne pożyczki udzielane przez rząd w Ankarze. Docelowo siła uzależnienia się północnej części wyspy od sąsiada z półwyspu Azji Mniejszej powoduje duże zagrożenie dla potencjalnej reintegracji Cypru.

Sytuacja polityczna Republiki Cypryjskiej jest o wiele bardziej stabilna, co wynika z jej członkostwa w wielu organizacjach międzynarodowych. Wsparcie, które państwo to otrzymuje ma również silny wpływ na jego rozwój gospodarczy. Ciągła obecność wojsk ONZ i Wielkiej Brytanii w większym stopniu nie utrudnia funkcjonowania państwa, a jest jedynie gwarantem pokoju na wyspie. Istotne jest podkreślenie tutaj wyjątkowego tempa, w którym zmienia się poziom życia mieszkańców, co jest wynikiem szybkiego progresu ekonomicznego, a także wykorzystania potencjału turystycznego. Państwo to jest na arenie międzynarodowej uznawane w pełni, jedyny wyjątek stanowi Republika Turcji, która by uniknąć kontradykcyjności w swojej dyplomacji, oficjalnie nie uznała Republiki Cypryjskiej. Decyzja ta jednak nie ma żadnego wpływu na faktyczne funkcjonowanie władz w Nikozji. Wydarzeniem, które najbardziej wzmocniło to państwo, jego niezależność oraz stabilność wewnętrzną, było jego wstąpienie do Unii Europejskiej (2004 r.). Potwierdziło ono nie tylko bezdyskusyjne uznanie tego państwa na arenie międzynarodowej, ale również przybliżyło je do kultury europejskiej, oddalając je zarazem od kultury islamu, co zostało również pogłębione odrzuceniem kandydatury Republiki Turcji.

Biorąc pod uwagę sytuację polityczną oraz ekonomiczną obu państw zauważyć można, że brak jest jakiejkolwiek chęci 
stron na rozwiązanie tego sporu. Doświadczenie nauczyło również, że ingerencja państw trzecich w tym przypadku nie jest zasadna i doprowadzić może jedynie do pogorszenia się sytuacji na wyspie. Potencjalne scenariusze dające szanse na ponowne współżycie tych narodów w jednym państwie należy uzależnić przede wszystkim od działalności Republiki Turcji. W związku z silnym uzależnieniem od niej TRCP jedynie jakakolwiek decyzja władz w Ankarze w zakresie zaprzestania wspierania małego quasi-państwa może doprowadzić do potencjalnych rozmów między mieszkańcami wyspy. Biorąc jednak pod uwagę strategiczne usytuowanie wyspy oraz silne ambicje tworzenia „wielkiego państwa” jest to scenariusz bardzo wątpliwy. Pozostaje zatem jedynie obserwować poglądy władz w Nikozji - jak długo zamierzają one tolerować aktualny stan faktyczny, a w którym momencie dokona ona uznania TRCP chcąc się od historii i problemów związanych z separatyzmem cypryjskim.

\section{Bibliografia}

Adamczyk A., Problem cypryjski, „Studia Europejskie” 1997, nr 4.

Adamczyk A., Proces integracji Republiki Cypru ze Wspólnotami Europejskimi i jego ewentualny wptyw na rozwiazanie problemu cypryjskiego, „Studia Europejskie” 1999, nr 4.

Ambroziak A., Aspiracje integracyjne państw śródziemnomorskich - Cypr, „Wspólnoty Europejskie” 1995, nr 4.

Bernard A., Republika Cypru. Kipriaki Dimokratia. Kibris Cumhuriyeti, Warszawa 1976.

Ciszek H., Wielka idea a budowanie jedności i tożsamości narodowej Greków, „Porównania” 2009, nr 6.

Cypr, Ministerstwo Spraw Zagranicznych, https://www.gov.pl/ web/dyplomacja/cypr. 
Cypr. Informacje o kraju, Informator Ekonomiczny Ministerstwa Spraw Zagranicznych, https://informatorekonomiczny.msz.gov.pl/pl/europa/cypr/.

Cypr Pótnocny - państwo, które teoretycznie nie istnieje, Forsal. pl, https://forsal.pl/artykuly/813700,cypr-polnocny-panstwo-ktore-teoretycznie-nie-istnieje.html.

Cyprus, OEC, https://oec.world/en/profile/country/cyp/.

Cyprus in Figures. 2013 edition, Report Np. 18, Press and Information Office for the Statistical Service, http://www.cy stat.gov.cy/mof/cystat/statistics.nsf/All/E3D6660151C37B35C2257DBD0034C3C3/\$file/CYPRUS_IN_FIGURES2013-EN-070114.pdf?OpenElement.

Cyprus Population 2020, http://worldpopulationreview.com/ countries/cyprus-population/.

Czekalski T., Problem Kosowa na tle stosunków albańsko-jugostowiańskich w latach 1944-1948, „Zeszyty naukowe Uniwersytetu Jagiellońskiego" 2011, r. MCCCXVIII.

Czubocha K., Paszkowska M., Konflikt cypryjski i jego wptyw na proces rozszerzenia Unii Europejskiej, „Zeszyty Naukowe Zakładu Europeistyki Wyższej Szkoły Informatyki i Zarządzania w Rzeszowie" 2007, nr 1 (3).

Dalidakis G.K., Enosis, The Union of Crete with Greece, https:// web.archive.org/web/20120425132526/http://www.dalidakis.com/Enosis the Union of Crete with Greece in 1913.pdf.

Faustmann H., Aktualne ogniska konfliktu. Konflikt na Cyprze odzwierciedleniem różnicy interesów we wschodniej części Morza Śródziemnego, http://www.eduvinet.de/comcult/ pdf/regiokonf/pl/cocpltla404.pdf.

Greek Cypriot police arrest staff of Israeli-owned firm, „The London Post", 22.12.2019, https://thelondonpost.net/greekcypriot-police-arrest-staff-israeli-owned-firm/.

Jelonek A., Dylematy konsocjonalizmu: przypadek Malezji, Warszawa 2004. 
Kanol B., Sustainable Tourism Development in Northern Cyprus and Prospects for Convergence, 2005, ResearchGate, https://www.researchgate.net/publication/237103626_Sustainable_Tourism_Development_in_Northern_Cyprus_ and_Prospects_for_Convergence.

KKTC, turizm rakamlarını 10 yılda 2-3'e katladı, „Dunya”, 26.03.2013, https://www.dunya.com/sektorler/turizm/kktc-turizm-rakamlarini-10-yilda-2-3039e-katladi-haberi-205658.

Kuczowicz K., Funkcjonowanie quasi-państwa w zjednoczonej Europie. Cypr Pólnocny, „Res Politicae. Prace Naukowe Akademii im. Jana Długosza w Częstochowie" 2013, t. V.

Osiewicz P., Wybory w państwie nieuznawanym na przykładzie Tureckiej Republiki Pótnocnego Cypru, [w:] Czy upadek demokracji? Wymiar praktyczny, red. A. Stelmach, Poznań 2007.

Paruch W., Między polityzacja etnosu a etnicyzacja demosu: refleksje o polityce narodowej na Batkanach, „Annales Universitatis Mariae Curie-Skłodowska Lublin - Polonia" 2016, vol. I.

Raczyńska M., Przebieg i skutki konfliktu cypryjskiego, „Zeszyty Naukowe Koła Studentów Stosunków Międzynarodowych Uniwersytetu Jagiellońskiego" 2013, nr 1 (4).

Śmigasiewicz M., Uwarunkowania geopolityczne państw nieuznawanych - casus Tureckiej Republiki Cypru Pótnocnego, „Przegląd Geopolityczny” 2014, t. 9.

Theodoulou C., The Cyprus Question: Some Facts, Ateny 1975. Turyści uciekaja przed terroryzmem, Cypr bije rekordy popularności, 18.07.2016, https://tvn24bis.pl/ze-swiata,75/rekordowy-naplyw-turystow-do-cypru,661851.html.

Yorucu V., The construction boom and environmental protection in Northern Cyprus as a consequence of the Annan 
Plan, „Construction Management and Economics” 2007, nr 25 (1).

\begin{abstract}
Abstrakt
Celem niniejszego artykułu jest przedstawienie aktualnej sytuacji politycznej, ze szczególnym uwzględnieniem jej konsekwencji, na Cyprze, gdzie obecne są silne tendencje separatystyczne. Autor niniejszego tekstu stawia tezę, że głównym czynnikiem napędzającym obecność i złożoność separatyzmu na wyspie jest działalność państw trzecich. Szczególny nacisk pozostanie nałożony na sytuację ekonomiczną stron sporu, z uwzględnieniem ich niezależności na arenie międzynarodowej, a także możliwości rozwoju gospodarczego, w tym w zakresie turystyki. Autor scharakteryzuje również separatyzm cypryjski, biorąc pod uwagę również znaczenie w tym zakresie poszczególnych idei „Wielkiego Państwa". Tendencje separatystyczne są coraz bardziej zauważalne w państwach europejskich. Zagrażają one bezpieczeństwu zarówno na poziomie lokalnym, regionalnym, jak i również światowym. Odpowiednie przyjrzenie się na złożoność tego zjawiska pozwoli w sposób właściwy regulować kwestię wspólnot wielonarodowych i etnicznych, aby zapobiec ich negatywnym konsekwencjom.
\end{abstract}

Słowa kluczowe: separatyzm, mniejszości narodowe, bezpieczeństwo, polityka gospodarcza, stosunki międzynarodowe, Morze Śródziemne, Unia Europejska

\title{
Abstract
}

The purpose of this article is to present the current political situation, with particular regard to its consequences, in Cyprus, where strong separatist tendencies are present. The author of this text argues that the main factor driving the presence and complexity of separatism on the island is the activity of third countries. Particular emphasis will remain on the economic situation of the parties to the dispute, including their independence on the international stage, as well as opportunities for economic development, including in the field of tourism. The author also characterizes Cypriot Separatism, also taking into account the importance of individual ideas of the "Great State" in this respect. Separatist tendencies are becoming more and more noticeable in Euro- 
pean countries. They threaten safety at all levels: local, regional and also global. A proper look at the complexity of this phenomenon will allow to properly regulate the issue of multinational and ethnic communities in order to avoid negative consequences

Keywords: separatism, national minorities, safety, economic policy, international relations, Mediterranean Sea, European Union 


\section{Dyplomacja kulturalna Włoch na przykładzie działalności Włoskich Instytutów Kultury w Japonii}

\section{„Miękka siła” - twarde priorytety}

83 Włoskie Instytuty Kultury (Istituto Italiano di Cultura), działające w różnych miejscach świata, są miejscem spotkań i dialogu intelektualistów i artystów, szerszej publiczności państw przyjmujących, ale także Włochów za granicą, chcących przede wszystkim kultywować relacje z krajem. Instytuty promują wizerunek Włoch zarówno pod hasłem „kultury włoskiej”, szczególne miejsce przyznając regionalnemu dziedzictwu kulturowemu i tradycjom lokalnym. Nie oznacza to, że promują jedynie elementy „klasyczne” czy historię - wręcz przeciwnie, ponieważ głównym medium przekazywanych przez te instytuty treści jest szeroko pojęta sztuka współczesna.

Instytuty Kultury są głównym narzędziem włoskiego soft power $^{1}$ - ich zastosowaniem jest nawiązywanie i utrzymywanie przyjaznych stosunków międzynarodowych. Propagowanie kultury i dyplomatyczne działania kulturalne, prowadzone przez Instytuty, przekładają się na międzypaństwowe relacje - zarówno społeczne, jak i ekonomiczne.

1 Ważną pozycją z tego zakresu, wyjaśniającą mechanizmy działania soft power, jest publikacja: J. Nye, Soft Power. Jak osiagnać sukces w polityce światowej, tłum. J. Zaborowski, Warszawa 2007. 
Włoskie Instytuty Kultury organizują wydarzenia związane ze sztuką, muzyką, kinem, literaturą, teatrem, tańcem, modą, designem, fotografią i architekturą; prowadzą kursy języka włoskiego i kultury; promują kulturę naukową Włoch; zarządzają bibliotekami, wideotekami. Włoskie Instytuty Kultury również ułatwiają kontakty między włoskimi i zagranicznymi podmiotami kulturalnymi - zapewniają wsparcie informacyjne i logistyczne dla publicznych i prywatnych operatorów kultury, zarówno włoskich, jak i zagranicznych.

\section{Wybrane wątki z historii Instytutów Kultury we Włoszech}

Pierwsze Włoskie Instytuty Kultury powstawały przede wszystkim w Europie: w 1932 r. w Brukseli i w 1939 r. w Madrycie. Większość z nich, jednak nie wszystkie, ma swoją siedzibę w stolicy państwa przyjmującego, a na terenie niektórych krajów funkcjonuje ich więcej niż jeden. Wśród działających na całym świecie Włoskich Instytutów Kultury osiemnaście znajduje się w Amerykach (w tym pięć w Stanach Zjednoczonych), osiem w Afryce, piętnaście w Azji, dwa w Australii i zdecydowana większość, bo ponad połowa, ma swoje siedziby w Europie.

Historia Włoskich Instytutów Kultury jest tak złożona, jak sama rola kultury w polityce. Pierwsze Włoskie Instytuty Kultury za granicą, utworzone dekretem królewskim w 1926 r., narodziły się z idei promowania i rozprzestrzeniania się włoskiej kultury oraz rozwijania relacji intelektualnych z zagranicą. Oprócz wymienionego, ogólnego zadania instytutów, już ustawa z 1926 r. przewidywała inicjatywy skupiające się wokół samego języka włoskiego, co również jest bardzo istotne w obecnym wymiarze dyplomacji kulturalnej Włoch². Insty-

2 Libro Bianco - L'italiano nel mondo che cambia, Ministero degli Affari Esteri e della Cooperazione Internazionale, Rzym 2017. 
tuty, od początku ich utworzenia, zobowiązane były do prowadzenia kursów językowych, wykładów i konferencji, a także działalności dotyczącej publikacji związanych z historią, myślą i sztuką Włoch ${ }^{3}$.

Instytuty Włoskie od samego początku swojego istnienia podległe były włoskiemu Ministerstwu Spraw Zagranicznych - służyły jako punkt odniesienia dla ambasad i konsulatów (zwanych wówczas Królewskimi Przedstawicielami Zagranicznymi), miały promować w poszczególnych placówkach sztukę wysoką. Początkowe regulacje prawne, dotyczące funkcjonowania Włoskich Instytutów Kultury, ustanawiały, że kierujący placówkami byli nominowani bezpośrednio przez ministra lub jego współpracowników ${ }^{4}$. To zarządzenie sprawiło, że Instytuty przez pewien czas, szczególnie na początku swojego istnienia, stały się placówkami propagandy kulturalnej reżimu ${ }^{5}$.

Instytuty nie posiadały w swoim statucie funkcji podtrzymywania więzi z ojczyzną Włochów, którzy wyemigrowali w poprzednich dekadach. Działanie to należało do tak zwanych Domów Włoskich, istniejących do końca XIX w., które pełniły raczej funkcje ośrodków społecznych, a nie kulturalnych ${ }^{6}$.

Obecna nazwa placówek to Istituto Italiano di Cultura all'estero $^{7}$ - dosłownie oznacza to: Włoski Instytut Kultury za granicą. Nazwa ta wskazuje i akcentuje fakt, że mimo iż jest to

3 G. Beghini, R. Fiorani, E. Giacomin, E. Gregori (red.), La diplomazia culturale. Forza del dialogo, potere della cultura. Le opportunità per l'Italia, Rzym 2013.

4 T. Colacicco, La propaganda fascista nelle università inglesi. La diplomazia culturale di Mussolini in Gran Bretagna (1921-1940), Mediolan 2018.

5 S. Santoro, L'Italia e L'Europa orientale. Diplomazia culturale e propaganda 1918-1943, Mediolan 2005.

6 A. Carrera, Gli strumenti istituzionali per la promozione della cultura italiana all'estero, [w:] Storia della letteratura italiana, red. L. Formisana, E. Malato, Rzym 2002, vol. 12.

7 Nazwa nadana przez dekret ministerialny z dn. 24 czerwca $1950 \mathrm{r}$. 
włoskie miejsce, to tworzona i prezentowana tam kultura nie jest wyłącznie włoska. Taka terminologia, a co za tym idzie nowe podejście do działalności Instytutów Włoskich, powstała dopiero po II wojnie światowej, kiedy liczba instytutów znacznie wzrosła. Trzeba podkreślić, że po wojnie, aż do 1990 r., nie zostały przeprowadzone większe zmiany ustawy z 1926 r. W ciągu 74 lat zmiany dokonywane były na poziomie regulacji dotyczących wyboru dyrektorów, którzy nie tylko winni być ludźmi z kręgów kultury, ale i swoistymi menadżerami kultury $^{8}$; zbliżenia placówek do społeczności emigracji włoskiej; modyfikacji i określenia nowego kryterium wyboru personelu. Dopiero głębszej reformy dokonano ustawą 401 z 1990 r. ${ }^{10}$

\section{Tożsamość Włoch a kultura włoska}

Temat tożsamości narodowej był wielokrotnie podnoszony zarówno w samej koncepcji tożsamości Włochów, jak i promocji kultury włoskiej. Przez lata dyskusja na temat tego problemu angażowała przedstawicieli takich dyscyplin naukowych, jak historiografia, antropologia, psychologia, socjologia, a także nauki polityczne. Tożsamość ludzi można zdefiniować na podstawie aspektów ekonomicznych, charakterystycznych dla społeczeństwa, polityki, kultury, historii i ekosystemu ${ }^{11}$. Poszukiwanie definicji tożsamości narodowej, a także innych rodzajów tożsa-

8 Circolare del Ministero degli affari esteri n. 42 del 21 giugno 1955 r.

9 Circolare del Ministero degli affari esteri n. 13 del maggio 1978 r.

10 Ustawa 401 z 22 grudnia 1990 r. Riforma degli Istituti italiani di cultura e interventi per la promozione della cultura e della lingua italiane all'estero.

11 E. Bojek, Doktrynalne determinacje włoskich koncepcji podziału terytorialnego państwa, „Studia Erasmiana Wratislaviensia, Wrocławskie Studia Erazmiańskie: zeszyt naukowy studentów, doktorantów i pracowników Uniwersytetu Wrocławskiego" 2007. 
mości, jest skomplikowane ze względu na skumulowane procesy geopolityczne i społeczne, na co zwrócił między innymi uwagę socjolog Anthony Giddens ${ }^{12}$. Na potrzeby niniejszego artykułu skupię się tylko na koncepcji włoskiej tożsamości narodowej w kontekście jej wizerunku poza granicami państwa.

Istotne zdaje się określenie różnicy między włoską tożsamością a tożsamością narodową, przy czym pierwsza jest rozumiana jako znacznie szersza koncepcja samej tożsamości narodowej, podczas gdy druga zakłada element państwowości. Trudno mówić o tożsamości narodowej przed XVIII w., ponieważ wówczas nie istniały ku temu żadne polityczne i instytucjonalne przesłanki ${ }^{13}$. Włochy są krajem, który ma najdłuższy proces identyfikacji w historii Zachodu (wynikający z historii). Włochy powstały w 1861 r., kiedy koronowano Wiktora Emanuela II na króla Zjednoczonego Królestwa Włoch. Mimo że powstałe państwo określano jako „państwo narodowe i unitarne", Włochy były nadal państwem wielonarodowym - przede wszystkim ze względu na silne tożsamości regionalne obecne na terytorium kraju ${ }^{14}$.

Według włoskiego historyka Luigiego Salvatorelli tożsamości narodowa zrodziła się dzięki pracy elity intelektualnej i działań budowanych na szeroko pojętej kulturze i sztuce o różnej, niejednorodnej naturze i pochodzeniu, podkreślającej różnorodność Włoch. Widać te procesy w muzyce Giuseppe Verdiego, wierszach Alessandro Manzoniego, powieściach Franceco Guerrazziego i wielu innych utworach artystycznych ${ }^{15}$.

12 Zob. A. Giddens, Nowoczesność i tożsamość. „Ja” i społeczeństwo w epoce późnej nowoczesności, tłum. A. Szulżycka, Kraków 2010.

13 M. Noviello, Region w geografii i polityce włoskiej, „Przegląd Geopolityczny" 2018, nr 25.

14 W. Rewera, Historyczne mniejszości językowe we wtoskich regionach o statutach specjalnych, Lublin 2017.

15 L. Salvatorelli, Sommario della storia d'Italia dai tempi preistorici ai giorni nostri, Turyn 1938. 
Ta myśl może wyjaśniać sposób prowadzenia włoskiej dyplomacji kulturalnej, prowadzonej w szerszym kontekście polityki zagranicznej. Kultura stanowi dla Włoch podstawowy instrument podkreślania znaczenia i roli na arenie międzynarodowej. Dzięki przemyślanemu korzystaniu z dziedzictwa kulturalnego, Włochy mogą czerpać znaczne korzyści i osiągać długoterminowe rezultaty. W budowaniu marki i spójnego przekazu konieczna była synergia obejmująca elementy kulturowe poszczególnych regionów. Takie podejście wymagało rewizji narzędzi promocji kultury, które musiały być tak zaprojektowane, by umożliwić włączenie się regionów jako aktywnych podmiotów tworzących politykę zagraniczną ${ }^{16}$.

Włoskie władze lokalne w znacznym stopniu przyczyniają się do realizacji projektów w dziedzinie kultury - promowanych przez rząd - i są również zdefiniowane jako nowe narzędzia dyplomacji kulturalnej. W tym kontekście jednym z głównych celów Ministerstwa Spraw Zagranicznych jest prowadzenie działalności kulturalnej we współpracy z regionami, prowincjami, gminami, władzami lokalnymi, fundacjami i innymi podmiotami działającymi na rzecz rozwoju i wzmocnienie dziedzictwa za granicą. Element sprzyjający współpracy to statut regionów, który zawiera rozdziały poświęcone rozwojowi i rozpowszechnianiu kultury, a także współpracy z organami państwowymi, w tym poza granicami kraju ${ }^{17}$. Do głównych celów w dziedzinie kultury należą: realizacja i promocja inicjatyw kulturalnych, ochrona i wzmocnienie dziedzictwa kulturowego i lokalnych tradycji, mobilizacja i włącznie do inicjatyw kulturalnych innych

16 N. Bonacasa, C. Costanzo (red.), Gestione, valorizzazione e promozione dei Beni Culturali. Esperienze a confronto. Atti della Giornata di studi, Palermo 2018.

17 Statut regionu Sycylia: Statuto speciale della Regione Siciliana, www. ars.sicilia.it/sites/default/files/downloads/2018-10/Statuto.pdf [dostęp: kwiecień 2019]. 
instytucji publicznych, a także prywatnych. W ramach współpracy międzynarodowej organy zobowiązują się do przyłączenia się do krajowych i międzynarodowych stowarzyszeń na rzecz ochrony wspólnych interesów oraz integracji i współistnienia różnych grup etnicznych; współpracują również z innymi organizacjami w celu promowania wszelkich form współpracy odpowiednich do włączenia działalności i lokalnego dziedzictwa do inicjatyw międzynarodowych ${ }^{18}$.

Aby ułatwić proces internacjonalizacji włoskie Ministerstwo Spraw Zagranicznych ustaliło szereg umów i porozumień z władzami lokalnymi, uniwersytetami i instytucjami kultury. Wśród wielu możemy wyróżnić: Region Emilia Romagna, który podpisał umowę umożliwiającą realizację wydarzeń kulturalnych za granicą przy wsparciu Włoskich Instytutów Kultury ${ }^{19}$; porozumienie z prowincją Pawia, która za pośrednictwem sieci Instytutów Kultury zaprezentowała kolekcje Fundacji Art Sartirana ${ }^{20}$; Region Piemontu, który podpisał umowę mającą na celu z jednej strony informowanie Departamentu Kultury regionu o planowanych przez wybrane instytuty kultury wydarzeniach, którymi potencjalnie mógłby być zainteresowany region Piemontu, a z drugiej wybrane Instytuty Włoskie, planując swoją działalność, mają brać pod uwagę potencjał i ofertę kulturalną regionu Piemont ${ }^{21}$. Nie tylko jednostki samorządu terytorialnego aktywnie współpracują z organami poza granicami - wśród umów z uniwersytetami możemy wymienić umowę podpisaną z Uniwersytetem w Kalabrii, której celem było promowanie pro-

18 F. Rutelli, La Diplomazia Culturale italiana. Il Patrimonio, le industrie creative e l'interesse nazionale, Rzym 2018.

19 „Bollettino Ufficiale della Regione Emilia-Romagna”, 12.12.2018, nr 390 .

20 Ministerstwo Spraw Zagranicznych i Stosunków Międzynarodowych, www.esteri.it/mae/it/politica_estera/cultura/documentazione/testi_ dich_intenti [dostęp: kwiecień 2019].

21 Turyn, 8 lipca 2001 r. 
cesu internacjonalizacji uniwersytetu poprzez wspieranie jego udziału w międzynarodowych projektach badawczych ${ }^{22}$.

\section{Przedsięwzięcia kulturalne Instytutów Włoskich (przykłady)}

Włoskie Instytuty Kultury prowadzą działalność dostosowaną do realiów kraju, w którym operują i to one, mając najlepszą wiedzę o środowisku i otoczeniu, tworzą interdyscyplinarny program swojej działalności w państwie przyjmującym.

Włoskie Instytuty Kultury organizują przedsięwzięcia, które w podobnym czasie odbywają się na całym świecie i koordynowane są przez włoskie MSZ. Flagowym projektem jest Tydzień Języka Włoskiego na Świecie (La Settimana della Lingua Italiana nel Mondo). W to wydarzenie, odbywające się regularnie od 2001 r., zaangażowana jest zarówno sieć kulturalna, jak i dyplomatyczna. Inicjatywa ma na celu upowszechnianie języka włoskiego. Program wydarzeń układany jest indywidualnie przez każdą z placówek, ale skoncentrowany wokół wybranego przez MSZ motywu przewodniego ${ }^{23}$.

Zintegrowane programy promocyjne obejmują również obchody rocznic szczególnym znaczeniu dla historii Włoch: Rok Goacchino Rossiniego w 2018 r., Rok Leonarda Da Vinci w 2019 r. czy Raffaello w 2020 r. W 2017 r. włoskie MSZ przyjęło „Plan ulepszenia promocji włoskiej kultury i języka” (Piano per il potenziamento della promozione della cultura e della lingua italiane), który przyjął koncepcję zintegrowanej promocji instytucjonalnej w celu zwiększenia jej wydajności. Duże znaczenie w programie ma wyznaczony obszar priorytetowy, w którym Włochy chcą umocnić swoją obecność poprzez interakcje z lo-

\footnotetext{
22 Neapol, 11 lipca $2001 \mathrm{r}$.

23 Ibidem.
} 
kalnymi społeczeństwami (poprzez podejście oparte na dialogu międzykulturowym $)^{24} .2017 \mathrm{r}$. był poświęcony Ameryce Łacińskiej, w 2018 r. największa uwaga była skupiona na regionie MENA, a w 2019 r. na Afryce Subsaharyjskiej. Jest to niejako połączenie dyplomacji kulturalnej z ekonomiczną i skonsolidowanie działalności Włoskich Instytutów ze strategiami polityk gospodarczych oraz polityk wizerunkowych, nie tylko samego państwa, ale również włoskich przedsiębiorstw i ośrodków akademickich.

\section{Kultura Włoch w Japonii}

Dwustronne stosunki między Japonią a Włochami rozpoczęły się formalnie 25 sierpnia 1866 r., ale pierwsze kontakty między oboma państwami sięgają co najmniej XVI w., kiedy to pierwsza japońska misja do Europy, kierowana przez Itō Mancio, dotarła do Rzymu w 1585 r.

W XIX w. Włochy i Japonia doświadczyły wielkich zmian w swoich politycznych i społecznych strukturach. Stosunki obu państw stopniowo stawały się coraz bliższe, czego kulminacją był udział tych państw w obu wojnach światowych jako sojuszników. Po II wojnie światowej Włochy i Japonia były zainteresowane odbudową systemu gospodarczego, który pozwoliłby im wyjść z katastrofalnej sytuacji, w jakiej znaleźli się po zakończeniu konfliktu. Sytuacja ta pomogła odnowić i zacieśnić umowy handlowe, a także rozbudzić współpracę naukową i technologiczną ${ }^{25}$.

Współczesne relacje włosko-japońskie są dobre. Oba państwa są członkami OECD, G7 i G8. Włochy wydają się być

24 Senat Republiki Włoskiej, www.senato.it/service/PDF/PDFServer/ DF/342335.pdf [dostęp: kwiecień 2019].

25 Ambasada Japonii we Włoszech, www.it.emb-japan.go.jp/150/it/yuujou.html [dostęp: kwiecień 2019]. 
jednym z najpopularniejszych krajów w Japonii i jednym z najpopularniejszych europejskich ośrodków turystycznych ${ }^{26}$.

$\mathrm{Z}$ analizy dynamiki, trendów i cech japońskiego rynku kulturalno-turystycznego wynika, że Japończycy wskazują Włochy jako jedną z głównych destynacji w Europie. Szczególnie cenią włoskie dziedzictwo kulturalne, ale przede wszystkim kuchnię. Podział korzyści dla poszczególnych regionów, wynikający z takiego stanu rzeczy, jest zróżnicowany. To punkt wyjścia i jednocześnie wstęp do refleksji nad możliwością popularyzacji wszystkich części Włoch, nie tylko tych oferujących dzieła sztuki światowej klasy ${ }^{27}$. Dlatego też w swoich programach działalności Włoskie Instytuty Kultury w Japonii uwzględniają nie tylko przekaz związany z „włoskością”, ale i - podkreślając różnorodność kraju - wyróżniają aspekty lokalne i szczególne dla danego regionu. Obecnie w Japonii działają dwa Włoskie Instytuty Kultury: w Tokio i Osace.

Historia włoskiego Instytutu Kultury w Tokio sięga 1939 r. i wiąże z hojnym gestem barona Takaharu Mitsui, który dał włoskiemu państwu na własność należącą do niego nieruchomość w celu założenia tam Włoskiego Domu Kultury. Inauguracja miała miejsce w marcu 1941 r. w obecności książąt cesarskich. Jednak działalność jednostki była krótka. W 1945 r., podczas II wojny światowej, budynek został zniszczony przez ataki powietrzne. Dopiero w 1959 r. udało się go całkowicie przebudować i tym samym wznowić działalność. Od 2005 r. Włoski Instytutu Kultury ma nową siedzibę, dostosowaną do potrzeb swojej obecnej działalności.

Instytut w Osace rozpoczął działalność w 1978 r., kiedy utworzono w Kioto sekcję zamiejscową Włoskiego Instytutu

26 Ibidem.

27 Raport Ministerstwa Spraw Zagranicznych i Włoskiej Narodowej Agencji Turystyki, www.esteri.it/mae/pdf_paesi/giappone_indice.pdf [dostęp: kwiecień 2019]. 
Kultury w Tokio. W 2010 r. oddział został przeniesiony do Osaki, a trzy lata później do obecnej lokalizacji, w wieżowcu Nakanoshima Festival Tower, obok Konsulatu Generalnego Włoch.

W programie Instytutów znajdują zarówno inicjatywy popularne, kierowane do szerokiej publiczności, które mają zwrócić uwagę na element włoski w miejskiej tkance tak różnorodnego miasta, jakim są Tokio i Osaka, jak i wydarzenia bardziej skoncentrowane na promocji samych artystów lub szczególnych aspektów włoskiej kultury, które są mało znane.

Oba Instytuty posiadają biblioteki. Bogatsza w zasoby biblioteka w Tokio posiada ponad 16 tys. pozycji w języku włoskim i około 6 tys. w języku japońskim. Ponadto w zasobach filmoteki znajduje się ponad 800 płyt DVD i CD, a także liczne czasopisma, które obejmują różne dziedziny: literaturę, beletrystykę, historię, sztukę i muzykę.

Działalność biblioteki w Tokio to nie tylko zarządzanie zasobami, ale i organizacja targów książki oraz organizacja konkursów - nagród literackich. Pierwsza z nich to nagroda „Fosco Maraini”. Ustanowiona w 2013 r., przyznawana jest twórcom japońskim za dzieła dotyczące Włoch. Nagroda ma celu zwiększenie wiedzy i rozpowszechnianie kultury włoskiej w Japonii. Wyróżnienie to nawiązuje do nagrody literackiej „Marco Polo”, przyznawanej w latach 1978-2007.

Drugim konkursem literackim jest nagroda "Suga Atsuko”. Wyróżnienie, ustanowione w 2014 r., nawiązuje do nagrody „Pico della Mirandola”, założonej w 1988 r. Jest to premiowanie najlepszych japońskich tłumaczeń włoskich książek.

Włoskie targi książki, które odbywają się co roku wiosną, nieprzerwanie od 2008 r. Wydarzenie obejmuje wystawę, połączoną ze sprzedażą, ponad 700 niedawno opublikowanych książek dotyczących Włoch, zarówno w języku japońskim, jak i włoskim. Wśród prezentowanych tytułów znajdują się podręczniki do nauki języka włoskiego, książki dla dzieci, książki kucharskie, 
przewodniki turystyczne, ale również książki na temat literatury i sztuki. Przy okazji targów odbywają się konferencje i seminaria prezentacyjne prowadzone przez autorów i tłumaczy ${ }^{28}$.

Jak zostało zaznaczone wcześniej, Włoskie Instytuty Kultury koncentrują się nie tylko na promocji kultury włoskiej, ale kultury w ogóle, choć w oczywiście w dużo mniejszym stopniu. W działalności jednostek można znaleźć inicjatywny dotyczące kultury, ale niebezpośrednio związanych ze sztuką, tematów dyskusyjnych, spornych, związanych z wartościami. Jednym z przykładów jest współpraca przy konferencji „No Justice Without Life" - dotyczącej kwestii związanych ze zniesieniem kary śmierci. Inną inicjatywą, niezwiązaną z kulturą włoską, ale tworzoną przez Włochów, jest prezentacja projektu \#1415IRAN autorstwa Giorgio Cosulich de Pecine i Giulio Napolitano. Projekt dwóch fotografików przedstawia współczesne życie w Iranie na podstawie zdjęć umieszczane w mediach społecznościowych ${ }^{29}$.

W harmonogramach działalności obu Instytutów regularnie pojawiają się spotkania z artystami włoskimi, którzy w swojej działalności inspirują się kulturą Japonii. Wśród najpopularniejszych należy wymienić: „Kimonomania - Young Italian Designers Pay Tribute to Kimono" (kolekcja kimon stworzona przez włoskich projektantów w 2018 r.) oraz „Il tempo disegnato. Ricordi e riflessioni di un mangaka italiano" (spotkanie z jednym z najbardziej znanych włoskich projektantów komiksów, Igortem, w 2015 r.) $)^{30}$.

28 Włoski Instytut Kultury w Tokio, www.iictokyo.esteri.it/iic_tokyo/it/ la-biblioteca/la-biblioteca/biblioteca.html [dostęp: kwiecień 2019].

29 Włoski Instytut Kultury w Tokio, www.iictokyo.esteri.it/iic_tokyo/ it/gli_eventi/calendario/2015/12/il-tempo-disegnato-ricordi-e-riflessionidi-un-mangaka-italiano.html [dostęp: kwiecień 2019].

30 Włoski Instytut Kultury w Tokio, www.iictokyo.esteri.it/iic_tokyo/it/ gli_eventi/calendario/2019/03/kimonomania-young-italian-designers.html [dostęp: kwiecień 2019]. 


\section{Walory różnorodności}

Znaczącym elementem w programach Instytutów Włoskich w Japonii jest akcentowanie, a tym samym wzmacnianie interesów gospodarczych, kulturowych i politycznych poszczególnych regionów. Instytuty, tworząc swój program wydarzeń, analizują czynniki kształtujące specyficzny charakter włoskich regionów. Są to między innymi elementy historyczne, geograficzne, ekonomiczne, związane z tradycją i językiem. Włoska dyplomacja kulturalna wychodzi z przekonania, iż podkreślanie zróżnicowania Włoch, a zatem bogactwa kulturowego, jest korzystne zarówno dla indywidualnych regionów, jak i dla całego kraju.

Wśród szeregu wydarzeń, podkreślających wartość zróżnicowania historyczno-kulturowego Włoch, było forum japońsko-włoskie w 2016 r.: Forum Giappone/Italia: design e territori. Il alore delle differenze (Forum Japonia/Włochy: projektowanie a terytorium. Wartość różnic) ${ }^{31}$. Wydarzenie w ramach Tygodnia Języka Włoskiego skupiło się na organizacji międzynarodowych, multidyscyplnarnych warsztatów dla młodych projektantów, które miały na celu pokazanie, że różnorodność, która charakteryzuje Włochy jest wartością dodaną w realizacji projektu.

Biorąc pod uwagę zmieniające się tendencje w społeczeństwie japońskim, Instytuty starają się wyjść naprzeciw pojawiającym się zainteresowaniom Japończyków. Z ostatnich obserwacji wynika, że w Japonii rośnie zapotrzebowanie na produkty spożywcze typowe dla różnych obszarów, podczas gdy we Wło-

31 Włoski Instytut Kultury w Tokio, www.iictokyo.esteri.it/iic_tokyo/it/ gli_eventi/calendario/2016/10/forum-giappone-italia-design-e.html [dostęp: kwiecień 2019]. 
szech od lat 80 . były one sposobem i środkiem na drodze do rozwoju większości regionów państwa. Instytut Włoski w Tokio zorganizował w związku z tym spotkanie z japońskim eseistą Shimamurą Natsu, znanym z publikacji związanych z Włochami, które dotyczą przede wszystkim kina, ale także jedzenia i wina. Podczas konferencji przedstawione zostały produkty regionalne z różnych sektorów oraz ich historia, która przyczyniła się do ożywienia gospodarczego obszarów swojego pochodzenia. Spotkanie miało na celu z jednej strony upowszechnienie wiedzy o historii Włoch i jej odmiennych regionach, z drugiej natomiast promocję samych produktów spożywczych ${ }^{32}$.

\section{Enogastronomia}

Wydarzenia skupione na promocji włoskich produktów spożywczych oraz włoskiej oferty eksportowej zajmują szczególne miejsce w działaniach Włoskich Instytutów Kultury w Japonii. W programach działalności znaczącą część zajmują wydarzenia związane z enogastronomią, czyli połączeniem enologii i gastronomii. Enogastronomia to dyscyplina badająca relacje między obszarem (terytorium) a działaniami człowieka ukierunkowanymi na uprawę, transformację, handel i konsumpcję lokalnych produktów. Enoturystyka i enogastronomia to stały element w polityce zagranicznej Włoch. Enogastronomia włoska w Japonii nie oznacza tylko zestawu produktów - potraw i wina - które są wytwarzane w danym regionie, ale także „filozofię gastronomiczną", która leży u podstaw wyboru i postrzegania produktów spożywczych ${ }^{33}$.

32 Spotkanie pn. Prodotti locali, paesaggi da scoprire e la rinascita della provincia in Italia - Conferenza di Shimamura Natsu, saggista.

33 Projekt „Turismo Accessibile”, http://www.turismoaccessibile.eu/ siteon/index.php/progetto-turismo-gastronomico/definizione-turismo-gastronomico [dostęp: kwiecień 2019]. 
Włoski Instytut Kultury w Osace oferuje możliwość uczestniczenia w kursach degustacji wina i jedzenia - oprócz standardowych zajęć związanych z nauką języka włoskiego, literatury, sztuki i architektury. Regularnie organizowane kursy enogastronomiczne mają na celu wyjaśnienie metody produkcji, tradycji i sposobów jedzenia sera, wraz z prawidłową jego kombinacją z winem.

Organizowane spotkania skupiają się przede wszystkim wokół trzech typowych produktów pożywczych Włoch: oliwy z oliwek, sera i wina. Pierwsza seria spotkań skoncentrowana jest na pojedynczych produktach i ich historii (warsztaty dotyczące sera: Il formaggio stagionato amato persino da Carlo Magno "Ser dojrzewający ukochany nawet przez Karola Wielkiego”; wina: Programma di S. Valentino „Vini da Dessert” - „Walentynkowy program: wina deserowe”; oliwy z oliwek: "Che cos'e' lolio extra vergine di oliva?” - „Co to jest oliwa z oliwek?”) ${ }^{34}$.

Druga część proponowanych kursów promuje wybrany region za pomocą typowych produktów specyficznych dla obszaru, np. „Varietà autoctona pugliese Primitivo” („Apulijska odmiana Primitivo”); „Viaggiare l'Italia tramite l'olio d'oliva: Toscana” („Podróżuj po Włoszech poprzez oliwę z oliwek: Toskania”; „Viaggiare l'Italia attraverso $i$ vini: la Regione della Valle D’Aosta” („Podróżuj po Włoszech dzięki winom regionu Valle D’Aosta”). Warsztaty kulinarne poświęcone regionalnej włoskiej kuchni prowadzone są przez sommelierów, kucharzy, krytyków kulinarnych - zarówno włoskich, jak i japońskich. Ponadto enogastronomia jest obowiązkowym elementem dużych wydarzeń poświęconych poszczególnym regionom - na przykład konferencja naukowa „La straordinaria varietà dei vini e della cultura alimentare siciliana” („Niezwykła różno-

34 Włoski Instytut Kultury w Osace, www.iicosaka.esteri.it/iic_osaka/it/ imparare_italiano/i_corsi_di_lingua/corsi-e-orari/seminari [dostęp: kwiecień 2019]. 
rodność sycylijskich win i kultury jedzenia”) podczas festiwalu „Sicilian Dream”35.

\section{Wydarzenia jednodniowe poświęcone regionom}

Wśród wydarzeń skupiających się na danym regionie Włoch organizowane są jednodniowe koncerty, spotkania, prezentacje, jak i dłuższe festiwale - poświęcone w całości pojedynczemu regionowi. Organizację tych drugich charakteryzuje holistyczne podejście do regionu i ukazywanie jego reprezentatywnych cech. Współorganizatorem takich festiwali są najczęściej jednostki samorządu terytorialnego - regiony, prowincje, gminy; regionalne instytucje kultury - teatry, opery, muzea; organizacje pozarządowe działające w sferze kultury i dialogu międzynarodowego - MUSA International, Società Italiana per l'Educazione Musicale.

Pośród licznych jednodniowych wydarzeń można wymienić „Serata gastronomica e musicale genovese” („Genueński wieczór gastronomiczno-muzyczny”), podczas którego odbył się koncert akustyczny wokalistki i aktorki Anny Marii Castelli i gitarzysty Simone Guiducci „Genua, miasto pisania piosenek”, a także degustacja typowych produktów lokalnych. Wydarzenie rozpoczęła prelekcja przybliżająca historię portowego i wielokulturowego miasta jakim jest Genua ${ }^{36}$.

Walentynki w Japonii cieszą się niezwykłą popularnością, a z roku na rok zyskują coraz więcej entuzjastów. Podobnie jest w przypadku innych popularnych świąt zachodnich, takich

35 Włoski Instytut Kultury w Osace, www.iicosaka.esteri.it/iic_osaka/ it/gli_eventi/calendario/2017/12/conferenza-di-isao-miyajima.html [dostęp: kwiecień 2019].

36 Włoski Instytut Kultury w Tokio, www.iictokyo.esteri.it/iic_tokyo/it/ gli_eventi/calendario/serata-gastronomica-e-musicale-genovese.html [dostęp: kwiecień 2019]. 
jak Halloween. Monitoring zmieniających się tendencji i trendów w japońskiej społeczności jest kluczowy dla tworzenia programu wydarzeń. Przy okazji lutowego święta zakochanych Włoski Instytut Kultury w Osace zorganizował spotkanie dotyczące samego wydarzenia - jego historii i zwyczajach, ale również był okazją do promocji Piemontu poprzez produkowane w regionie słynne czekoladki Bodrato Cioccolato ${ }^{37}$.

„Scopriamo la Sardegna, terra di misteri e d'incanti?" („Odkryjmy Sardynię, krainę tajemniczą i czarującą!") to seminarium, podczas którego zaprezentowane zostały zdjęcia i filmy związane z tradycyjnymi festiwalami odbywającymi się na Sardynii. Oprócz walorów turystycznych spotkanie miało na celu pokazanie odrębności i odmienności kultury sardyńskiej, poprzez ludowe obrządki - obchody święta św. Efizjusza, patrona wyspy ${ }^{38}$.

\section{Festiwale regionalne}

Jednym z przedsięwzięć, organizowanych wspólnie z władzami regionalnymi, jest „Apulia Japan Fest” w Tokio. Wydarzenie, organizowane od 2012 r., skupia się przede wszystkim na promocji regionu Apulia przez muzykę. Festiwal organizuje zarówno koncerty wybitnych kompozytorów, jak i daje możliwość wymiany akademickiej i artystycznej młodym muzykom. Program wydarzenia został tak zorganizowany, aby podkreślić współpracę muzyków z Włoch i Japonii, na przykład opery włoskie interpretowane przez śpiewaków z Tokyo Academy

37 Włoski Instytut Kultury w Osace, www.iicosaka.esteri.it/iic_osaka/it/ gli_eventi/calendario/san-valentino.html [dostęp: kwiecień 2019].

38 Włoski Instytut Kultury w Osace, www.iicosaka.esteri.it/iic_osaka/it/ gli_eventi/calendario/2018/04/scopriamo-la-sardegna-terra-di.html [dostęp: kwiecień 2019]. 
of Music w koncercie „Opera Italiana - Galà lirico” (2017) ${ }^{39}$; „Poznaj Włochy dzięki operze i muzyce sakralnej” - koncert wokalny japońskich uczniów klasy mistrzowskiej prowadzonej przez włoskiego Vito Clemente (2017). Festiwalowi towarzyszy wymiana akademicka i spotkania mające na celu internacjonalizację uniwersytetu w Bari poprzez wspólne projekty ${ }^{40}$.

Sycylia jest najaktywniej działającym regionem w Japonii. Flagowa inicjatywa Sicilia Fusion Japan trwała dwa lata (2017-2018) i w swoim interdyscyplinarnym programie zadbała o każdy element charakterystyczny dla regionu. Wykorzystany został fakt, że oba podmioty są wyspami i każde z nich ma swoją słynną górę - Fudżi i Etnę. Istotnym elementem był fakt przywiązania obu społeczeństw do swoich tradycji i dziedzictwa kulturowego, ale także wspólna część historii, relacje i wzajemne inspiracje. W ciągu tych dwóch lat zostały zorganizowane między innymi wizyty studyjne japońskich dziennikarzy do Włoch, rezydencje artystów, kursy kulinarne, degustacje włoskich restauracji i piekarni, które działają na terenie Japonii oraz szereg koncertów, wystaw i spotkań wokół literatury ${ }^{41}$.

\section{Podsumowanie}

Dyplomacja kulturalna daje duże możliwości rozwoju poszczególnym państwom w czasach trudnych dla gospodarki i staje się narzędziem dobrobytu, wzrostu gospodarczego i dialogu

39 Włoski Instytut Kultury w Tokio, www.iictokyo.esteri.it/iic_tokyo/ it/gli_eventi/calendario/2017/10/japan-apulia-festival-vi-edizione.html [dostęp: kwiecień 2019].

40 Włoski Instytut Kultury w Tokio, https://iictokyo.esteri.it/iic_tokyo/ it/gli_eventi/calendario/japan-apulia-festival.html [dostęp: kwiecień 2019].

41 Ministerstwo Spraw Zagranicznych i Relacji Międzynarodowych, https://www.esteri.it/mae/resource/doc/2017/12/sicilia_fusion_osaka_2017171122-a.pdf [dostęp: kwiecień 2019]. 
międzynarodowego ${ }^{42}$. Włochy są krajem niezwykle wdzięcznym do uprawiania dyplomacji - przede wszystkim ze względu na dziedzictwo historyczne, artystyczne, archeologiczne i krajobrazowe.

Nie bez znaczenia jest też różnorodność i ciągłość znaczenia „włoskości” w epokach kulturowych w historii ludzkości. To zintegrowane procesy i konsekwentna współpraca terytorialna pozwoliły na osiągnięcia na arenie międzynarodowej. Włosi szybko zrozumieli, że niewłaściwe byłoby zaniedbywanie rzeczywistości kraju wielobiegunowego i zdecentralizowanego. Włoska dyplomacja pokazuje, że kultywowanie tożsamości nie jest sposobem na zamknięcie się, a wręcz przeciwnie - jest narzędziem dialogu i mądrze prowadzoną taktyką na arenie międzynarodowej.

W komunikatach i strategii tworzonych dla danego kraju Włosi dostosowali swoją narrację do aktualnych kierunków i kursów obieranych przez oba społeczeństwa - Włoch i państwa przyjmującego. Ulepszyli ofertę, która już istniała - podkreślili wyjątkowość całego terytorium, współpracując przy tym z władzami lokalnymi, regionami, strukturami państwowymi i podmiotami prywatnymi. Wzrastająca tendencja poszukiwania w podróżach unikalnych doświadczeń sprzyja rozwojowi włoskiej dyplomacji kulturalnej, dając jej niewyczerpane zasoby zróżnicowanych kraju - produkty lokalne, pluralizm i różnorodność. Zrównoważony rozwój włoskiej turystyki jest jednocześnie produktem i nośnikiem włoskiej dyplomacji kulturalnej.

Na zakończenie warto wyraźnie zaznaczyć, że dyplomacja kulturalna, nie tylko włoska, jest dziś podwójnie ważna: powinna promować interes narodowy i przyczyniać się do stosunków

42 R. Łoś, Soft power we wspótczesnych stosunkach międzynarodowych, [w:] Stosunki międzynarodowe wokót zagadnień teoretycznych, red. K. Kącka, Toruń 2014. 
międzynarodowych opartych na dialogu i pokoju, w świecie szczególnie wrażliwym na nacjonalistyczne hasła.

\section{Bibliografia}

Ambasada Japonii we Włoszech, www.it.emb-japan.go.jp/150/ it/yuujou.html.

Beghini G., Fiorani R., Giacomin E., Gregori E. (red.), La diplomazia culturale. Forza del dialogo, potere della cultura. Le opportunità per l'Italia, Rzym 2013.

Bojek E., Doktrynalne determinacje wtoskich koncepcji podziatu terytorialnego państwa, „Studia Erasmiana Wratislaviensia, Wrocławskie Studia Erazmiańskie: zeszyt naukowy studentów, doktorantów i pracowników Uniwersytetu Wrocławskiego" 2007.

Bonacasa N., Costanzo C. (red.), Gestione, valorizzazione e promozione dei Beni Culturali. Esperienze a confronto. Atti della Giornata di studi, Palermo 2018.

Carrera A., Gli strumenti istituzionali per la promozione della cultura italiana all'estero, [w:] Storia della letteratura italiana, red. E. Malato, Rzym 2002, nr 12.

Colacicco T., La propaganda fascista nelle università inglesi. La diplomazia culturale di Mussolini in Gran Bretagna (1921-1940), Mediolan 2018.

Giddens A., Nowoczesność $i$ tożsamość. "Ja” i społeczeństwo w epoce późnej nowoczesności, tłum. A. Szulżycka, Kraków 2010.

Libro Bianco - L'italiano nel mondo che cambia, Ministero degli Affari Esteri e della Cooperazione Internazionale, Rzym 2017.

Łoś R., Soft power we wspótczesnych stosunkach międzynarodowych, [w:] Stosunki międzynarodowe wokót zagadnień teoretycznych, red. K. Kącka, Toruń 2014. 
Ministerstwo Spraw Zagranicznych i Relacji Międzynarodowych, www.esteri.it/mae/it.

Noviello M., Region w geografii i polityce wtoskiej, „Przegląd Geopolityczny" 2018, nr 25.

Nye J., Soft Power. Jak osiagnać sukces w polityce światowej, tłum. J. Zaborowski, Warszawa 2007.

Rewera W., Historyczne mniejszości językowe we włoskich regionach o statutach specjalnych, Lublin 2017.

Rutelli F., La Diplomazia Culturale italiana. Il Patrimonio, le industrie creative e l'interesse nazionale, Associazione Incontro di Civiltà, Rzym 2018.

Salvatorelli L., Sommario della storia d'Italia dai tempi preistorici ai giorni nostri, Turyn 1938.

Santoro S., L'Italia e L'Europa orientale. Diplomazia culturale e propaganda 1918-1943, Mediolan 2005.

Senat Republiki Włoskiej, www.senato.it/service/PDF/PDFServer/DF/342335.pdf.

Włoski Instytut Kultury w Osace, www.iicosaka.esteri.it. Włoski Instytut Kultury w Tokio, www.iictokyo.esteri.it.

\section{Abstrakt}

Podmioty polityczne wykorzystują kulturę do wspierania swojego potencjału miękkiej siły, tworzenia pozytywnej aury dla działań współpracy na wielu polach, $\mathrm{w}$ tym nauki, techniki, gospodarki i samego przemysłu kulturalnego, tworzenia powiązań społecznych, wreszcie do osiągnięcia celów międzynarodowych.

Rola, jaką odgrywa zewnętrzna polityka kulturalna - również regionalna - w utrzymaniu stosunków międzypaństwowych jest niezwykle istotna. Sztuka może łączyć państwa odległe nie tylko geograficznie, ale $\mathrm{i}$ kulturowo - $\mathrm{w}$ tym wypadku Włochy i Japonię.

Istotnym elementem włączenia kultury w działania polityczne Włoch było utworzenie osobnych jednostek działających w sferze kultury, będących komórką resortu spraw zagranicznych. Pierwsze Włoskie Instytuty Kultury powstały w 1926 r., kiedy to ich wartości nie można 
było przecenić, tak jak nie można było przewidzieć ich przyjęcia przez odmiennych kulturowo odbiorców. Przez swoje działania Instytuty Włoskie miały budować pozytywny obraz państwa, a tym samym fundamenty do przyszłej współpracy.

Kultura jest nieodłącznie związana z turystyką. Turystyka kulturalna stanowi jedną z najistotniejszych części sektora turystycznego. Wybór odwiedzanego miejsca determinowany jest przez jakość atrakcji związanych z szeroko pojętą kulturą. Dobry marketing w tej dziedzinie może wpłynąć nie tylko na decyzję o spędzeniu urlopu w danym kraju, ale i o zainwestowaniu w nim, a nawet zamieszkaniu. Szczególne miejsce ten rodzaj turystyki ma w polityce zagranicznej Republiki Włoskiej.

Celem niniejszego artykułu, w perspektywie zarysowanych powyżej problemów, jest przeanalizowanie i wskazanie, w jaki sposób Włoskie Instytuty Kultury wykorzystują narzędzia i metody dyplomacji kulturalnej w Japonii.

Słowa kluczowe: dyplomacja, kultura, Włochy, Japonia, dyplomacja kulturalna

\section{Abstract}

Political entities use culture to reinforce their soft power's potential, to create a positive basis for cooperation in many fields, including science, technology, economy and the cultural industry, to create social relationships and, what is crucial, to achieve international goals. The key role of external cultural policy - also regional - is extremely important to achieve and maintain good international relations. Art can connect distant countries not only geographically but also culturally - as in the case of Italy and Japan.

An important element of including culture in the Italian policy was setting up the individual units of the Ministry of Foreign Affairs operating in the sphere of culture. The first Italian Institutes of Culture were created in 1926. Their value during that era could not be overestimated as it was impossible to expect their adoption by culturally different audiences. Through their activities the Italian Institutes build a positive image of the state and thus the foundations for future cooperation.

Culture is inseparable from the tourism. Cultural tourism is the crucial part of the modern-day world. Choosing the place to visit is determined by the quality of attractions related to the culture. Good marketing design may affect not only the decision to spend a holiday in certain 
country but also to invest in this country or even to live in it. This type of tourism has a particular importance in the Italian foreign policy.

The purpose of this article is to analyze and identify how the Italian Cultural Institutes use tools and methods of cultural diplomacy in Japan.

Keywords: diplomacy, culture, Italy, Japan, cultural diplomacy 


\section{Agnieszka Esin Lesiczka \\ Uniwersytet Warszawski}

\section{Nauczanie języka tureckiego w Czechach i na Słowacji}

Zainteresowanie Turcją na ziemiach dzisiejszej Republiki Czeskiej i Słowacji przez lata utrzymywało się na wysokim poziomie. Stosunki czesko-tureckie i słowacko-tureckie sięgają XVI w. Część ziemi należących do Republiki Czeskiej była opanowana i zarządzana przez Turków, w przeciwieństwie do ziem dzisiejszej Słowacji, które nigdy nie stały się częścią Imperium Osmańskiego. Turkologia na ziemiach dawnej Czechosłowacji przez lata współtworzona była przez Instytut Orientalistyki Uniwersytetu Karola w Pradze, Instytut Orientalistyki Uniwersytetu Komeńskiego w Bratysławie, Instytut Orientalistyki Czechosłowackiej Akademii Nauk oraz Czechosłowackie Centrum Badań Wschodnich. Wiele turkologicznych artykułów publikowano w czasopiśmie naukowym „Archiv Orientalni”; języka tureckiego uczono natomiast w Państwowej Szkole Językowej oraz na Wydziale Literatury i Języka Rosyjskiego na Uniwersytecie Komeńskiego. Dzisiejsza kondycja badań i studiów turkologicznych w Czechach i na Słowacji w ostatnich latach uległa diametralnej przemianie.

Prawie 70-letnią historię oraz obecny stan turkologii na ziemiach byłej Czechosłowacji jest bardzo trudno rozdzielić pomiędzy Czechy i Słowację ze względu na fakt, że w latach 1918-1938 oraz po II wojnie światowej w latach 1945-1992, kraje te funkcjonowały jako jedno państwo. Aby nie powtarzać tych samych badań oraz informacji o turkologii podczas anali- 
zowania Czech oraz Słowacji jako oddzielne państwa, oba kraje zostały zawarte w jednym referacie, ponieważ turkologia, jej stan i historia w tych państwach są ze sobą ściśle powiązane poprzez te same postaci, tych samych turkologów, historię, te same problemy oraz wspólne badania.

\section{Turkologia na Uniwersytecie Karola w Pradze}

Uniwersytet Karola w Pradze (po czesku: Univerzita Karlova), to uniwersytet założony 7 kwietnia 1348 r. przez króla Karola IV (1316-1378). Przed I wojną światową funkcjonował pod nazwą Uniwersytetu Czeskiego albo Niemieckiego Uniwersytetu Karola w Pradze. Następnie został rozdzielony na dwa oddzielne uniwersytety: Uniwersytet Niemiecki i Uniwersytet Czeski. Ten najstarszy uniwersytet Europy Środkowej, naucza obecnie 50,5 tys. uczniów na siedemnastu wydziałach. Studiuje na nim około 9 tys. obcokrajowców. Wg światowych rankingów uczelni jest jednym z najlepszych uniwersytetów Europy Wschodniej. W roku akademickim 2018/2019 zajął 274. miejsce w rankingu światowym ${ }^{1}$.

Turkologia, jako dziedzina nauki będąca częścią orientalistyki, została zapoczątkowana w drugiej połowie XIX w. Bardzo szybko rozprzestrzeniająca się na terenie Europy, a zarazem najdłużej trwająca na świecie moda, czyli moda na „orient” zaczęła zyskiwać swoich zwolenników również w Czechach. Tratując zainteresowanie tą modą jako punkt wyjściowy, w XIX w. zaczęła się rozwijać orientalistyka, a wraz z nią turkologia. Historię turkologii na ziemiach czeskich podzielić można na pięćokresów:

1. od XIX w. do powstania Czechosłowacji (1918);

1 Round University Ranking 2018, Charles Univeristy in Prague, http://roundranking.com/universities/charles-university-in-prague.html?sort $=$ O\&year $=2018 \&$ subject $=$ SO [dostęp: 21.12.2018]. 
2. od powstania Czechosłowacji do II wojny światowej i początku rządów komunistycznych (1948);

3. pierwszy okres komunizmu (lata 50. i 60.);

4. drugi okres komunizmu (lata 70. i 80.);

5. po Aksamitnej rewolucji (1989) ${ }^{2}$.

Natomiast w ostatnich latach stan turkologii na Uniwersytecie Karola w Pradze nie przedstawia się najlepiej.

Pierwszym profesorem orientalistyki w historii Czech został w 1891 r. Max Grünert (1849-1929) prowadzący badania w zakresie języka arabskiego, perskiego i osmańskiego. Profesor stał się niezaprzeczalnym autorytetem w dziedzinie orientalistyki w Czechach. Z tego względu, idąc za jego przykładem, każdy kto chciał zostać orientalistą musiał tak jak Grünert nauczyć się trzech orientalnych języków, a następnie mógł zająć się badaniem Bliskiego Wschodu, jego historii, kultury i literatury. Oprócz wspomnianego profesora, Karl Jahn (1906-1985) otrzymał stopień doktora habilitowanego w zakresie języka perskiego i tureckiego podczas II wojny światowej. Nie pozostał jednak na Uniwersytecie Karola. Przeszedł po jakimś czasie na Uniwersytet $\mathrm{w}$ Leyden, gdzie został profesorem ${ }^{3}$.

Historia turkologii na Uniwersytecie Karola jako oddzielnego kierunku, sięga lat 50. XX w. Aż do 1990 r. na omawianej uczelni nie powstał kierunek który nazywano by dosłownie „turkologią”. Jednakże w Katedrze Języków Orientalnych przez wiele lat nauczano języka osmańskotureckiego, historii Osmanów, tureckiej kultury i literatury. W latach 50., pod kierownictwem sławnego turkologa prof. Josefa Blaškoviča (1910-1990), Jan Rypka (1886-1968) oraz Felix Tauer (1893-1981) rozpoczęli nauczanie języka tureckiego w Katedrze Bliskiego i Środ-

2 Z. Yüksel, Çek Cumhuriyeti'nde Türkolojinin Tarihi, [w:] Prof. Dr. Fikret Türkmen Armağanı, red. G. Gülsevin, M. Arıkan, Izmir 2005, s. 767.

3 F. Tauer, Prag Üniversitesinde Son Yüzyılda Arapça, Farsça ve Türkçe Tetkikleri, „Şarkiyat Mecmuası» 1966, nr VI, s. 69. 
kowego Wschodu na Wydziale Literatury ${ }^{4}$. Blaškovič nauczał natomiast dialektów tureckich, folkloru, prowadził seminaria z historii i literatury ${ }^{5}$.

Jan Rypka i Felix Tauer prowadzili badania i kwarantanny naukowe głównie w stambulskich bibliotekach. Rypka prowadził również seminarium iranistyczne. Zajmował się przede wszystkim turecką poezją. Dziedziną zainteresowań badawczych Tauera była historia Imperium Osmańskiego. Natomiast Blaškovič prowadził badania nad współczesną literaturą turecką .

Blaškovič, Rypka, Tauer oraz inni wykładowcy wychowali kilka roczników czechosłowackich turkologów. Od otwarcia Katedry Bliskiego i ŚrodkowegoWschodu do 1980 r. turkologię ukończyło 15 osób. W latach 1950-1970 na turkologii uczyło się dwanaście studentów. Natomiast dwóch studentów zostało absolwentami omawianego kierunku w latach 1975 i 1976. Kiedy pod koniec lat 70. Josef Blaškovič odszedł na emeryturę, do 1990 r. turkologia funkcjonowała, choć nie działała już tak prężnie jak wcześniej ${ }^{7}$.

Wzmocnienie i rozpoczęcie od nowa badań turkologicznych na Uniwersytecie Karolaw Pradze stało się możliwe po upadku komunizmu i rozpadzie Czechosłowacji. W roku akademickim 1990/1991 Tomáš Laněin (1944) utworzył turkologię, która odtąd funkcjonować miała jako oddzielny kierunek studiów. Już w pierwszym roku naboru studentów, program spotkał się z ogromnym zainteresowaniem ze strony kandydatów. W 1993 r. otwarto równolegle dwie grupy turkologii.

4 F. Tauer, op.cit., s. 65.

5 V. Kopčan, Blaškovič, Josef (1910-1990), [w:] TDV İslam Ansiklopedisi, t. 6, İstanbul 1992, s. 245.

6 F. Emecen, V. Kopčan, Çekoslovakya, [w:] TDV İslam Ansiklopedisi, t. 8, İstanbul 1992, s. 257.

7 T. Laně, Çek Cumhuriyeti’nde Türkçe Öğrenimi, Avrupa'da Yabancı Dil Olarak Türkçe Öğretimi Sempozyumu, Ankara, 25-26.10.2001. 
Od roku akademickiego 2017/2018 turkologia na Uniwersytecie Karola w Pradze funkcjonuje w Katedrze Badań nad Środkowym Wschodem na Wydziale Sztuki. Od roku akademickiego 2019/2020 nie będzie już istniała turkologia jako oddzielny kierunek. Zamiast niej otwarty zostanie kierunek badania nad Środkowym Wschodem, w ramach którego uczyć się będzie można wszystkiego tego, czego dotychczas nauczano w Katedrze Badań nad Wschodem, to znaczy języków, kultur, literatury i historii krajów orientalistycznych. W ramach tego programu wszyscy studenci będą mieli pewne, z góry ustalone dla wszystkich wykłady. Jednak ktoś, kto aplikując na kierunek badania nad Środkowym Wschodem, już na początku jako specjalność wybierze turkologię, będzie mógł ukończyć ją jako specjalista w zakresie turkologii. Programy poszczególnych specjalności będą więc funkcjonowały w sposób pararelny w stosunku do faktycznego kierunku studiów ${ }^{8}$.

\section{Turkologia na Uniwersytecie Komeńskiego w Bratysławie}

Uniwersytet Komeńskiego w Bratysławie (po słowacku: Univerzita Komenského v Bratislave) został założony w 1919 r., po powstaniu Czechosłowacji. Jest najstarszym, największym, i najlepszym spośród publicznych uniwersytetów Słowacji. Wzorem dla uczelni była Academia Istropolitna założona w Bratysławie w 1465 r. przez węgierskiego króla Matthiasa Corviniusa. W 1939 r. uniwersytet zmienił nazwę na Uniwersytet Słowacki. Jednak w 1954 r. oficjalnie powrócił do pierwotnej nazwy. Obecnie na uniwersytecie kształci się 22860 studentów. W rankingu 2018 World University Ranking uczelnia zajęła 391. miejsce?.

8 E. Akcasu, Stalowa Wola-Prag, 28 Aralık 2018.

9 Round University Ranking 2018, Comenius University in Bratislava. 
Jednym z najstarszych wydziałów Uniwersytetu Komeńskiego jest Wydział Filozofii, który został założony w 1921 r. dzięki zaangażowaniu wykładowców z Uniwersytetu Karola w Pradze. To właśnie na tym wydziale w 1960 r. otwarty został Instytut Orientalistyki. Po II wojnie światowej, przed 1960 r. prawdopodobnie nikt nie prowadził na terenie dzisiejszej Słowacji badań naukowych dotyczących Turcji, Iranu lub państw arabskich. W latach 1960-1965 J. Bakoš, będący kierownikiem Instytutu Orientalistyki, co roku wydawał czasopismo naukowe „Asian and African Studies"10.

Profesor Blaškovič, a wraz z nim dwóch jego uczniów, absolwentów turkologii Uniwersytetu Karola: Vojtech Kopčan oraz Xenia Celnarova, przez wiele lat starali się o to, aby na Uniwersytecie Komeńskiego nauczano języka tureckiego. Wynikiem tych starań stało się skierowanie przez dziekana Wydziału Filozoficznego pracujących jako turkolodzy w Instytucie Nauk o Wschodnie w Akademii Naukowej Kopčana oraz Celnarovą na program przygotowujący do nauczania tureckiej literatury, historii oraz języka. Stało się to już po przejściu prof. Blaškoviča na emeryturę. Na Wydziale Filozoficznym, w ramach założonego programu, miano nauczać zarówno współczesnego tureckiego, używanego w Republice Tureckiej, jak i osmańsko-tureckiego. Pierwszym problemem, który pojawił się jeszcze przed zrealizowaniem projektu, była kwestia związana z zajęciami praktycznego nauczania języka tureckiego, bowiem zarówno Kopčan, jak i Celnarova nie mieli doświadczenia w konwersacji w języku tureckim. Ponadto zainteresowanie językiem tureckim wśród studentów było nikłe. W czasach, kiedy projekt miał być wprowadzony w życie, większość Słowaków nie miała

İnternet erişim adresi: http://roundranking.com/universities/comenius-university-in-bratislava.html?sort=O\&year=2018\&subject=SO [dostęp: 23.12 . 2018].

10 F. Emecen, V. Kopčan, op.cit., s. 258. 
perspektyw na wyjazd do Turcji. Ostatecznie projekt nie został zrealizowany ${ }^{11}$.

Wspominając o badaniach turkologicznych prowadzonych na Uniwersytecie Komeńskiego, powiedzieć należy o wspólnym projekcie Petracka, Blaskovica i Veselya. Członkowie Instytutu Orientalistyki przygotowali katalog perko-turecko-arabskich tekstów, zakupionych od Bośniaka Safveta Beg Basagica $^{12}$. W Bratysławie turkologiczne badania naukowe prowadzi Vojtech Kopčan'ın (1940-). Obszarem jego zainteresowań są głównie sprawy związane ze sposobem zarządzania ziemiami Imperium Osmańskiego oraz opisami Słowacji spisanymi przez Evliyę Çelebiego. Dr. hab. Xsenia Celnarova zajmuje się natomiast współczesną literaturą turecką ${ }^{13}$.

Obecnie na Uniwersytecie Komeńskiego w Bratysławie nie funkcjonuje kierunek turkologiczny. Język turecki jest na tym uniwersytecie nauczany jedynie jako lektorat do wyboru dla osób studiujących na innych kierunkach. Przeważnie na początku każdego roku akademickiego otwierane są cztery grupy lektoratu języka tureckiego. Wg danych opublikowanych przez Instytut Yunus Emre, aby stworzyć turkologię na omawianej uczelni, należałoby wysłać na nią odpowiedniego profesora z Turcji ${ }^{14}$. 4 czerwca $2012 \mathrm{r}$. Instytut Yunus Emre podpisał protokół o współpracy z Uniwersytetem Komeńskiego. Zdaniem Ambasador Republiki Tureckiej w Bratysławie Aslıgül Üğdül, Uniwersytet Komeńskiego jest na terenie Słowacji centrum

11 X. Celnarova, Slovakya Türkçe’nin Öğretilmesinin Sağlanması, Avrupa'da Yabancı Dil Olarak Türkçe Öğretimi Sempozyumu (25-26 Ekim 2001), http://www.turkceogretimi.com/yabancilara-turkceogretimi/slovakya-turkceninogretilmesinin-saglanmasi [dostęp: 28.12.2018].

12 F. Emecen, V. Kopčan, op.cit., s. 257.

13 Ibidem, s. 258.

14 Çalıştay Tertip Kurulu, I. Uluslararası Türkoloji Çalıştayı El Kitabı, Ankara 2012, s. 181. 
turkologii ${ }^{15}$. Jest nim nawet w sytuacji, gdy turkologia na nim nie istnieje, ze względu na fakt, że jest to najważniejsze miejsce, w którym na Słowacji nauczany jest język turecki. W celu kontynuowania procesu nauczania tego języka, Instytut Yunus Emre przez wiele lat deleguje na bratysławski uniwersytet lektorów języka tureckiego. Ze względu na brak kierunku turkologicznego, lektorzy prowadzą zajęcia z podstaw języka dla studentów języka i literatury rosyjskiej. Umowę podpisują nie z uniwersytetem, lecz z delegującym ich Instytutem Yunus Emre w Ankarze, który utrzymuje lektorów pracujących na omawianej uczelni.

Podsumowując, na Uniwersytecie Komeńskiego czy też mówiąc najogólniej na terenie Słowacji turkologia nigdy nie powstała. Na uczelni można uczyć się języka tureckiego jedynie w ramach lektoratów do wyboru, będąc studentem Wydziału Filozofii. Za zajęcia student otrzymuje cztery punkty ECTS. Zajęcia trwają cztery godziny lekcyjne tygodniowo. Studenci mogą uczyć się w grupach na poziomie A1-A2, B1-B2 lub C1-C2. 2-3 najzdolniejszych uczniów wysyłanych jest na stypendium - Letnią Szkołę Języka Tureckiego, organizowane przez Instytut Yunus Emre w Ankarze ${ }^{16}$.

Dla Słowaków chcących nauczyć się języka tureckiego, problematycznym może okazać się fakt, że nie powstał dotąd turecko-słowacki słownik. Tureccy tłumacze i uczniowie korzystają przeważnie ze słowników turecko-rosyjskich, turecko-niemieckich albo turecko-angielskich.

\section{Zakończenie}

Historia turkologii na ziemiach obecnej Rpeubliki Czeskiej jest dosyć długa i owocna w wiele ważnych badań naukowych. $\mathrm{Na}$

15 A. Üğüdül, Büyükelçinin Mesajı, http://bratislava.be.mfa.gov.tr/Mission/Message [dostęp: 2.01.2019].

16 A. Kılıç, Stalowa Wola-Kayseri, 27 Aralık 2018. 
Uniwersytecie Karola w Pradze wychowanych zostało kilka pokoleń turkologów. Turkologia jako kierunek studiów wciąż jeszcze w Pradze funkcjonuje, choć od przyszłego roku akademickiego nie będzie już działać jako niezależny kierunek studiów.

Sytuacja turkologii na ziemiach obecnej Słowacji nigdy nie była dobra. Słowaccy turkolodzy, absolwenci Uniwersytetu Karola w Pradze, pracowali i pracują na przykład w Instytucie Orientalistyki Akademii Nauk. Pomimo starań nie udało im się jednak doprowadzić do nauczania literatury i historii tureckiej. Język być może również nie byłby nauczany, gdyby nie fakt, że lektora utrzymuje strona turecka.

\section{Bibliografia}

Blaşkoviç J., Çekoslovakya'da Türklük, İstanbul 2008, www. babil.com/cekoslovakyada-turkluk-kitabi-josef-blaskovic.

Celnarova X., Slovakya Türkçennin Öğretilmesinin Sağlanması, Avrupa'da Yabancı Dil Olarak Türkçe Öğretimi Sempozyumu (25-26 Ekim 2001), http://www.turkceogretimi.com/ yabancilara-turkceogretimi/slovakya-turkceninogretilmesinin-saglanmasi.

Emecen F., Kopčan V., Çekoslovakya, [w:] TDV İslam Ansiklopedisi, t. 8, İstanbul 1992.

Güzel A., Dış Ülkelerde Yabancılara Grafiklerle Türkçe Öğretimi Üzerine Bir Model, [w:] III. Uluslararası Dünya Dili Türkçe Sempozyumu Bildiri Kitabl, red. İ. Yazar, İzmir 2010.

Katalogy a databáze Národní knihovny ČR, Tomáš Laně (1944-), http://aleph.nkp.cz/F/?ccl_term=wau=jn200007 $10411+$ or $+w k w=j n 20000710411 \&-$ func $=$ findc $\&$ local base $=$ skc. 
Kopčan V., Blaškovič, Josef (1910-1990), [w:] TDV İslam Ansiklopedisi, t. 6, İstanbul 1992.

Kopčan V., Rypka, Jan (1886-1968), [w:] TDV İslam Ansiklopedisi, t. 35, İstanbul 2008.

Kopčan V., Tauer, Felix (1893-1981), [w:] TDV İslam Ansiklopedisi, t. 40, İstanbul 2011.

Kučera P., Çek Türkolojisine Tarihî Bir Bakış, 1971, http://t24. com.tr/k24/yazi/cek-turkolojisi.

Kučera P., Translations from Turkish in Czech Republic, 1990-2010, Praha 2010.

Laně T., Çek Cumhuriyeti'nde Türkçe Öğrenimi, Avrupa'da Yabancı Dil Olarak Türkçe Öğretimi Sempozyumu, Ankara, 25-26.10.2001.

Round University Ranking 2018, Charles Univeristy in Prague, http://roundranking.com/universities/charles-university-in-prague.html? sort $=$ O\&year $=2018 \&$ subject $=S O$.

Round University Ranking 2018, Comenius University in Bratislava, http://roundranking.com/universities/comenius-university-in-bratislava.html? -sort $=$ O\&year $=2018 \&$ subject $=$ SO.

Tauer F., Prag Üniversitesinde Son Yüzyllda Arapça, Farsça ve Türkçe Tetkikleri, „Şarkiyat Mecmuası" 1966, nr VI.

Üğüdül A., Büyükelçinin Mesajl, http://bratislava.be.mfa.gov. tr/Mission/Message.

Yüksel Z., Çek Cumhuriyeti’nde Türkolojinin Tarihi, [w:] Prof. Dr. Fikret Türkmen Armağanı, red. G. Gülsevin, M. Arıkan, Izmir 2005.

Çalıştay Tertip Kurulu, I. Uluslararası Türkoloji Çalıștayı El Kitabl, Ankara 2012. 


\title{
Abstrakt
}

Znajomość Bliskiego Wschodu i Turcji na terytorium obecnej Republiki Czeskiej i Słowacji ma stosunkowo długą historię. Stosunki czesko-tureckie oraz słowacko-tureckie zmieniały się na przestrzeni wieków, przyjmując różne oblicza. Z czasem na ziemiach omawianych krajów rozpoczęto badania nad Bliskim Wschodem, a następnie również nad Turcją. Historia badań turkologicznych rozpoczęła się około 70 lat temu. Studia turkologiczne zapoczątkowano za czasów Czechosłowacji. Ówczesne, wspólne dla dzisiejszych Czech i Słowacji uniwersytety, instytucje, organizacje, naukowcy, publikacje, kierunki studiów i biblioteki funkcjonowały jako jeden twór aż do 1992 roku. Z tego względu trudno jest podzielić historię badań turkologicznych między te dwa kraje, które miały w swoich historiach tych samych turkologów, te same kierunki studiów i badań. Instytucjami, które przez te 70 lat wspierały i kształtowały badania turkologiczne, były przede wszystkim: Instytut Orientalistyczny Uniwersytetu Karola w Pradze, Instytut Orientalistyczny Uniwersytetu Comeniusa, Czechosłowacka Akademia Nauk, Czechosłowackie Centrum Studiów Bliskiego Wschodu i Publiczna Szkoła Języków Obcych w Pradze. Dziedziny prowadzonych przez te instytucje badań, problemy badawcze, problemy i historia, będące przedmiotem niniejszej analizy, są kluczem do zrozumienia obecnej sytuacji badań turkologicznych w Czechach i na Słowacji oraz ich miejsca w turkologii europejskiej.

Słowa kluczowe: turkologia, turkologia w Europie, nauczanie języka tureckiego, Republika Czeska, Słowacja, studia turkologiczne

\begin{abstract}
The absorption in Middle East and Turkey on the territory of current Czech Republic and Slovakia date backs to the mists of history. The international relations between Czech Republic and Turkey as well as Slovakia and Turkey was changing during their long history. Turkology studies were available for Czechs and Slovakians also in former Czechoslovakia. Common universities, institutions, organizations, scientists, books, studies, libraries were working together for many years without any fracture till 1992. For this reason it is hard to divide the history of Turkology studies among this two countries having the same turkologists, history of Turkish studies, research questions and delvings. To be sure, the history of Turkology studies in both of this nations lasts
\end{abstract}


about 70 years. The institutions that was supporting and foster Turkology studies were primarily Institute of Oriental Studies on the Charles University, Institute of Oriental Studies on the Comenius University, Czechoslovakia Academy of Sciences, Czechoslovakia Center of Middle East Studies and Prag Public School of Foreign Languages. Their fields of studies, research questions, griefs and history which pose a subject of this project are actually a key to understand the nowadays situation of Turkology studies in Czech and Slovakia and their place in Turkology studies in the Europe.

Keywords: Turkology in Europe, teaching, Turkish language, Czech Republic, Slovakia, Turkology studies 


\section{Adrianna Czarnecka}

Uniwersytet Milkołaja Kopernika w Toruniu

ORCID ID: https: / orcid.org/0000-0002-1879-4924

\section{Rola kobiecych jednostek YPJ w walce z tzw. Państwem Islamskim}

\section{Wstęp}

Kobiety odgrywają strategiczną rolę w wolności i niezależności narodów oraz w pokoju i sprawiedliwości społecznej. Równość płci, sprawiedliwość społeczna, życie wolnej organizacji i tożsamości są ważne dla społeczeństwa. Nie były one przygotowane na zmiany zachodzące podczas konfliktu, ponieważ zamknięte były w roli nadanej przez tradycje społeczeństwa. Można stwierdzić, że zmiany i stworzenie nowego modelu kobiety walczącej jest efektem braku zgody na przemoc stosowaną przez umocnione jednostki tak zwanego Państwa Islamskiego (IS, ISIS, ISIL) wykorzystującego chaos w Syrii do utworzenia kalifatu z ekstremistyczną odmianą prawa opartą na prawie szariatu.

Konflikt w Syrii okazał się być długoletnim wyzwaniem dla środowiska międzynarodowego. Panujący tam chaos i złożoność konfliktu poprzez pojawienie się kilku frontów walki stały się idealnym miejscem dla rozwoju organizacji terrorystycznych, takich jak tak zwane Państwo Islamskie. Charakteryzujące się brutalnością swoich działań wobec wybranych grup etnicznych, takich jak Jazydzi czy Kurdowie. Grupa ta walcząca o tereny mogące zostać włączone w terytorium kalifatu odnosiła sukcesy na polu walki. Zarówno siły armii syryjskiej, jak i siły międzynarodowej kolacji nie były w stanie powstrzymać powiększającej się potęgi tak zwanego Państwa Islamskiego. 
Do powstania artykułu poddane zostały analizie materiały pochodzące z oficjalnych źródeł Kobiecych Jednostek Ochrony, artykuły prasowe, materiały video, a także publikacje naukowe. W ostatnim czasie temat Kurdów i jednostek walczących z tzw. Państwem Islamskim stał się popularny. Powstało wiele artykułów naukowych analizujących osiągnięcia militarne, a także role wyżej wymienionych grup w kreowaniu pokoju w Syrii, jednakże autor nie znalazł publikacji, w której przedstawiono całościową rolę kobiecej grypy YPJ obejmującą wszystkie aspekty ich oddziaływania, a także ich wpływ zarówno na politykę, jak i aspekt socjalno-społeczny. Poddane analizie zostały oddziały działające na terenie Syrii i Iraku.

YPJ zawiera jeden z największych kontyngentów zbrojnych kobiet bojowników na świecie. Poglądy polityczne wokół samej jednostki różnią się znacznie, jednak oczywistym jest fakt, że popieranie praw kobiet w podstawie politycznej, społecznej i gospodarczej równości mężczyzn odgrywa dużą rolę w społeczeństwie. Można zasugerować, że zyskały one poczucie tożsamości poprzez ruch kurdyjskich kobiet i dołączanie oraz wspieranie ruchu partyzanckiego. Czyniąc to, nie tylko przyczyniły się znacząco do obalenia tradycyjnych ról płciowych i stereotypów, ale również, co bardzo ważne, ujawniło kobietę jako wojownika, żołnierza, obrońcę innych kobiet na wojnie; obaliły role bardziej tradycyjne i kulturowe związane z mężczyznami i męskość.

Role kobiecych jednostek kurdyjskich należy analizować pod względem kilku aspektów, takich jak: wojskowe, psychologiczne i społeczne. Uwzględnienie tych trzech elementów pozwoli na całościowe przedstawienie ich wpływu zarówno na społeczność kurdyjską, zbudowanie wizerunku na arenie międzynarodowej, a także sukcesów w walce i oporze względem tzw. Państwa Islamskiego. Z doniesień prasowych i oficjalnych dokumentów stron zaangażowanych w konflikt w Syrii możemy stwierdzić, 
że kobiece jednostki odegrały istotną rolę w walce $\mathrm{z}$ islamistami. Wartym zaznaczenia jest fakt, iż oddziały te są tematem spornym w świecie polityki. Jednakże autor skupił się na faktach dotyczących ich zaangażowania w walce z ISIS, współpracy militarnej, a także wpływu na środowisko wewnętrzne i zewnętrzne w wąskim kontekście. YPJ zawiera jeden z największych kontyngentów zbrojnych kobiet bojowników na świecie. Poglądy polityczne wokół samej jednostki różnią się znacznie, jednak oczywistym jest fakt, że popieranie praw kobiet w zakresie politycznym, społecznym i gospodarczym, w tym równości z mężczyznami odgrywa dużą rolę w społeczeństwie. Można zasugerować, że kurdyjskie kobiety zyskały poczucie tożsamości poprzez ruch kurdyjskich kobiet oraz dołączanie i wspieranie ruchu partyzanckiego. Czyniąc to nie tylko przyczyniły się znacząco do obalenia tradycyjnych ról płciowych i stereotypów, ale również, co bardzo ważne, ujawniło kobietę jako wojownika, żołnierza, obrońcę innych kobiet na wojnie; zmieniły rolę bardziej tradycyjnie i kulturowo związane z mężczyznami i męskością.

\section{Czynniki wpływające na uformowanie się kobiecych jednostek}

Konflikt w Syrii rozpoczął się w 2011 r. i był skutkiem ogólnego poruszenia arabskiej ludności na Bliskim Wschodzie nazywanej Arabską Wiosną Ludów. To trwająca latami wielostronna wojna domowa w Syrii toczona między Ba'athist Syryjską Republiką Arabską pod przewodnictwem syryjskiego prezydenta Baszara al-Assada, a także sojusznikami krajowymi i zagranicznymi oraz różnymi siłami krajowymi i zagranicznymi przeciwstawiającymi się zarówno rządowi Syrii, jak i sobie nawzajem $^{1}$. Niepokoje w Syrii, będące częścią szerszej fali pro-

1 Syria's civil war explained from beginning, Al-Jazeera, 2017, https:// 
testów przeciwko Arabskiej Wiośnie w 2011 r., wyrosły z niezadowolenia z syryjskiego rządu i przerodziły się w konflikt zbrojny po gwałtownym stłumieniu protestów wzywających do usunięcia Assada².

\section{Powstanie YPJ}

Grupa ta powstała jako bezpośrednia odpowiedź na rosnące zagrożenie ze strony Państwa Islamskiego w Syrii: zagrożenie nie tylko dla regionu, ale także dla płci. Dehumanizacja kobiet przez tzw. Państwo Islamskie jest dobrze znana i jednym z głównych powodów, dla których kobiety podjęły walkę przeciwko grupie powstańczej. „Państwo Islamskie ma podwójne podejście do kobiet. Jedni uważają je za heretyków jako niemal podludzkich, jako towary do handlu i rozdawane były jako nagrody bojownikom dżihadystów". Polityka wobec tej grupy etnicznej nazywanej Yazydami okazała się być drastyczna, prowadząca do przymusowych wysiedleń. Schwytane kobiety i młode dziewczyny wykorzystywane były jako niewolnice seksualne, które sprzedawano na rynkach na terytorium IS lub rozdawane jako narzeczone dla dżihadystów ${ }^{3}$. Płeć żeńska okazała się również niezbędna dla Państwa Islamskiego. Zachęcając muzułmańskie kobiety do emigracji do kalifatu, aby wyprodukowały następne pokolenie bojowników „Jihadi”.

www.aljazeera.com/news/2016/05/syria-civil-war-explained-160505084 119966.html.

2 Syrian Troops Open on Protestors in Several Cities, „The New York Times" 2011 https://www.nytimes.com/2011/03/26/world/middleeast/26syria. html.

3 Szokująca instrukcja ISIS. Państwo Islamskie radzi, jak sprzedawać, bić i gwatcić niewolnice, „Polska Times” 2015 2015, https://polskatimes.pl/ szokujaca-instrukcja-isis-panstwo-islamskie-radzi-jak-sprzedawac-bic-igwalcic-niewolnice/ar/3684422. 
Brutalność IS tylko podsyciła Kurdyjki do dołączenia do YPJ, co dało okazję do zwiększenia swoich szeregów.

Kobiety brały udział w walkach kurdyjskiego ruchu oporu w Syrii już w 2011 r., kiedy założono YXG mieszanej płci, a później w 2012 r. zmieniono ich nazwę na YPG. YPJ została założona jako organizacja ściśle kobieca 3 kwietnia 2013 r. z pierwszym batalionem utworzonym $\mathrm{w}$ Jindires ${ }^{4}$. Wszystkie wojowniczki, które wcześniej były częścią mieszanych jednostek YPG, automatycznie stały się członkami YPJ. Początkowo w każdym z trzech kantonów Rojava był tylko jeden batalion YPJ, ale w każdej dzielnicy szybko utworzono bataliony, rozszerzając organizację. Pod koniec 2014 r. W YPJ było ponad 7 tys. ochotniczych bojowniczek w wieku od 18 do 40 lat. Do listopada 2016 r. liczba bojowników YPJ z Arabów i Kurdów wzrosła do 20 tys. Według stanu na sierpień 2017 r. grupa liczy 24 tys. członków ${ }^{5}$. W wojnie domowej w Syrii YPJ i YPG walczyły z różnymi grupami w północnej Syrii, w tym z Islamskim Państwem Iraku i Lewantu (ISIL), a także uczestniczyły w oblężeniu Kobanî od marca 2014 r. Współpracując z różnymi kurdyjskimi agencjami medialnymi informując, że „żołnierze YPJ stali się istotni w bitwie”. W bitwie pod Kobane, przed otrzymaniem poparcia mocarstw zachodnich, YPJ został zmuszony do powstrzymania ataków ISIL przy użyciu wyłącznie „starych rosyjskich kałasznikowów kupionych na czarnym rynku, ręcznych granatników i czołgów, które składali z pojazdów budowlanych i ciężarówek"6. Ponadto YPG, YPJ

4 M. Knapp, Revolution in Rojava: Democratic Autonomy and Women's Liberation in Syrian Kurdistan, 2016 https://justicenotchange.files.wordpress.com/2017/09/michael_knapp_ercan_ayboga_anja_flach_janet_bibok-org.pdf.

5 B. Argentieri, „Meet the female soldiers in Syria and Iraq fighting for gender equality as much as freedom, „The Telegraph” 2017, https://www. nytimes.com/2014/08/04/world/middleeast/iraq.html.

6 A Road Unforeseen: Woman Fight the Islamic State”, „Tax Meredith” 2016. 
i PKK uczestniczyły w operacji wojskowej w sierpniu 2014 r. na górze Sinjar, w której nawet 10 tys. Yazydów zostało uratowanych przed ludobójczymi atakami z rąk tzw. Państwa Islamskiego. Wraz z atakami lotniczymi z USA siły atakujące mogły stworzyć bezpieczną strefę 30 km (19 mil) dla uchodźców jazydzkich, aby uciec przed schwytaniem ISIL. Następnie uchodźcy zostali przeniesieni do północnej Syrii, a większość z nich później udała się w bezpieczniejsze rejony irackiego Kurdystanu ${ }^{7}$ YPJ uczestniczył w bitwach, takich jak ofensywa SDF przeciwko głównym twierdzom IS w Tabqa i Raqqa, służąc jako główne siły pomocnicze (wraz z YPG) dla Stanów Zjednoczonych.

YPJ jest politycznie dostosowana do PYD, która opiera swą libertariańską filozofię socjalistyczną na ideologii Abdullaha Öcalana, będącego liderem Partii Robotniczej Kurdystanu $(\mathrm{PKK})^{8}$. Centralnym punktem ideologii YPJ jest feministyczna ideologia PYD „Jineology”. Jest to teoretyczny zestaw pomysłów, które stworzą nową formę organizacji społecznej, która krytykuje podejście nauk społecznych, a bronią struktur państwa, patriarchatu i kapitału. Teoria ta ma na celu zbadanie nowych sposobów badania historii ludzkości w celu zinterpretowania, skąd wzięła się marginalizacja kobiet, proponuje nowy sposób spojrzenia na nauki społeczne ${ }^{9}$. Celem jest promowanie kobiet i społeczeństwa w dziedzinie wiedzy i nauki oraz doprowadzenie do kontroli przez nie wyżej wymienionych dziedzin, stawienie oporu męskiej władzy. Kobiety powinny mieć możliwość tworzenia własnych dziedzin naukowych oraz wypraco-

7 J. Varghese, ISIS Threat: Kurdish Forces Rescue 10,000 Yazidis from Sinjar Mountains, „International Business Times” 2014.

8 Official YPJ website, About us, 2019, https://ypjrojava.com/ypj/en/ about-us/.

9 We are Plan C, Jin, Jiyan, Azadi! Exeriences from the UK's first Jineology camp, 2019, https://www.weareplanc.org/blog/jin-jiyan-azadi-experiences-from-the-uks-first-jineologycamp/. 
wywania własnych interpretacji i znaczeń, aby mogły dzielić się nimi z resztą społeczeństwa.

\section{Powstanie i działalność tzw. Państwa Islamskiego}

Państwo Islamskie powstało jako Dżama’at al-Tawhid wal-dżihad w 1999 r., który przysięgał wierność Al-Kaidie i uczestniczył w powstaniu irackim po inwazji w Iraku w 2003 r. przez siły zachodnie na rozkaz Stanów Zjednoczonych. W czerwcu 2014 r. grupa ogłosiła się ogólnoświatowym kalifatem ${ }^{10}$. Jako kalifat domagał się religijnej, politycznej i wojskowej władzy nad wszystkimi muzułmanami na całym świecie.

W Syrii grupa ta przeprowadziła ataki naziemne zarówno na siły rządowe, jak i frakcje opozycyjne, a do grudnia 2015 r. miała duży obszar, rozciągający się od zachodniego Iraku po wschodnią Syrię, obejmujący około 8 do 12 mln ludzi, na którym egzekwował interpretację prawa szariatu ${ }^{11}$.

W dniu 3 sierpnia 2014 r. tzw. Państwo Islamskie zdobyło miasta Zumar, Sinjar i Wana w północnym Iraku ${ }^{12}$. Tysiące jazydów uciekło na górę Sinjar, bojąc się zbliżających się wrogich bojowników ISIL. Musieli oni borykać się z rosnącym zapotrzebowaniem na żywność i wodę oraz zagrożeniem ludobójstwem wobec nich i innych osób ogłoszone przez tzw. Państwo Islamskie. Większość terytorium kontrolowanego przez ISIS znajdowało się we wschodniej Syrii. Obejmowało dziewięć prowincji syryjskich, obejmujących większość kraju i leżących w dużej

10 B. Roggio, ISIS announces formation of Caliphate, rebrands as "Islamic State”, „Long War Journal” 2014, https://www.longwarjournal.org/ archives/2014/06/isis_announces_formation_of_ca.php.

11 S. Brike, How ISIS Rules, „The New York Review of Books” 2017, https://www.nybooks.com/daily/2014/12/09/how-isis-rules/.

12 T. Arango, Sunni Extermists in Iraq Seize 3 Towns From Kurds and Threaten Major Dam, „The New York Times” 2014, https://www.nytimes. com/2014/08/04/world/middleeast/iraq.html. 
mierze wzdłuż istniejących granic prowincji: Al Barakah (gubernator al-Hasakah), Al Khayr (gubernatorstwo Deir ez-Zor), Raqqa, Homs, Halab, Idlib, Hamah, Damaszek, i Latakia ${ }^{13}$. Później podzielił terytorium pod swoją kontrolą, aby utworzyć nowe prowincje Al-Furat, Fallujah, Dijla i al-Dżazira ${ }^{14} .9$ grudnia 2017 r. irackie siły zbrojne ogłosiły, że wojna przeciwko ISIL w Iraku została wygrana i że nie kontrolują już terytorium w Iraku. W czerwcu 2017 r. filia IS Khalid ibn al-Walid Army zaczęła nazywać siebie „Wilayat Horan”, miesiąc później media IS zaczęły nazywać wszystkie swoje roszczenia w Syrii „Wilayat al-Sham”.

\section{Rola społeczna i psychologiczna}

Kobiety tradycyjnie odgrywają ważną rolę w społeczeństwie i polityce kurdyjskiej. Ogólnie rzecz biorąc, prawa i równość kobiet kurdyjskich uległy dramatycznej poprawie w XXI w. z powodu postępowych ruchów w społeczeństwie kurdyjskim $^{15}$. Zmiany, które zaszły po wybuchu konfliktu zbrojnego w Syrii w społeczności kurdyjskiej w rzeczywistości stanowi to prawdopodobnie najbardziej feministyczną rewolucję, jaką świat widział (przynajmniej w czasach nowożytnych). Wcześniej w tym regionie obowiązywała wiejska obyczajowość, w której za normalne uchodziły śluby z małymi dziewczynkami oraz zamykanie kobiet w domach. Teraz te tradycje zostały obalone i zawieranie małżeństw $\mathrm{z}$ nieletnimi zostało uznane za niezgodne z prawem. W każdej dziedzinie życia publicznego powołano do

13 ISIS „Southern Division” praises foreign suice bom bers, „The Long War Journal” 2014, https://www.longwarjournal.org/archives/2014/04/isissouthern-division.php.

14 The Soufan Group, The Islamic State, November 2014.

15 Kurdish women's movement reshapes Turkish politics, „Al-Monitor” 2016, https://www.al-monitor.com/pulse/originals/2015/03/turkey-women-in-middle-east-figen-yuksekdag.html. 
życia niezależne kobiece organizacje, począwszy od kobiecych oddziałów milicji, czyli wspomnianych YPJ, a kończąc na kobiecych gminach i blokach mieszkaniowych. Idea obrony przed wrogimi siłami stanowi jedną z naczelnych zasadą rewolucji w Rożawie. Oprócz zapewnienia kobietom równych praw, feministyczne ruchy w Rożawie miały również na celu położyć kres hierarchiczności i dominacji we wszelkich aspektach życia dążąc do kompletnego przekształcenia stosunków społecznych oraz zrównaniu wszystkich ludzi, niezależnie od wieku, pochodzenia czy płci. Celem tych zmian ma być stworzenie w pełni harmonijnego oraz ekologicznego społeczeństwa ${ }^{16}$.

Ważnym elementem mobilizacji kobiet i utworzenie regularnych jednostek walczących okazała się konsekwencja tych działań. Mówi się o wybuchu rewolucji kobiecej na terenie północnej Syrii. Kurdyjskie kobiety były zaangażowane w rewolucję społeczną poprzez wyzwolenie kobiet. Odbywało się to poprzez wiele różnych wydarzeń, w tym zgromadzenia kobiet i programy reedukacyjne, których celem było ich nauczanie oraz mężczyzn. Dało to kobietom możliwość zdobycia wiedzy politycznej, władzy i niezależności w patriarchalnym społeczeństwie. Ten sposób myślenia rodzi ideę, że wolność dla wszystkich można osiągnąć poprzez wolność dla kobiet ${ }^{17}$. Kobiety z nowo odkrytym poczuciem wolności doświadczą prawdziwego wyzwolenia społecznego. Ważne jest również, aby niektóre poglądy ideologiczne, polityczne i gospodarcze były tworzone w oparciu o wolność kobiet. Na Bliskim Wschodzie, aby tego rodzaju transformacja miała miejsce. Kobieta i młodzież muszą zagwarantować zmianę w społeczeństwie. Dlatego też grupa została doceniona przez feministki za skon-

16 R. Carner, The Kurds ' Democratic Experiment, „The New York Times” 2015, https://www.nytimes.com/2015/09/30/opinion/the-kurds-democratic-experiment.html.

17 Ibidem. 
frontowanie się z tradycyjnymi oczekiwaniami dotyczącymi płci i przedefiniowanie roli kobiet w tym konflikcie. Odgrywają rolę w zmienianiu islamskiego myślenia i tradycji społecznych, biorąc broń. Te kobiety zmieniają w ten sposób swoją społeczność. YPJ przyciągnął uwagę międzynarodową jako przykład znaczącego osiągnięcia kobiet w regionie, w którym są systematycznie krzywdzone. Stały się przykładem wzięcia odpowiedzialności za swój los i stanęły do walki obok mężczyzn na tych samych warunkach ${ }^{18}$. Oprócz zapewnienia kobietom równych praw, feministyczne ruchy w Rożawie mają również na celu położyć kres hierarchiczności i dominacji we wszelkich aspektach życia - dążą do kompletnego przekształcenia stosunków społecznych oraz zrównaniu wszystkich ludzi, niezależnie od wie$\mathrm{ku}$, pochodzenia czy płci. Celem tych zmian ma być stworzenie w pełni harmonijnego oraz ekologicznego społeczeństwa ${ }^{19}$.

Kurdyjki stały się motywacją dla kobiet z regionu Bliskiego Wschodu dodając im wiary w możliwość podjęcia wali z oprawcami, czego przykładem jest rozszerzenie jednostek o arabskie i jazydzkie kobiety, które YPJ wyzwolili z rąk ISIS. Pozwoliło to na moralne umocnienie pozycji kobiety, która w tradycyjnym społeczeństwie była splamiona honorem, poprzez role niewolnicy seksualnej w strukturach ISIS ${ }^{20}$. YPJ z powodzeniem zmienia także sposób postrzegania świata przez Kurdów, muzułmańskich kobiet oraz kobiet z Bliskiego Wschodu. Pojawienie się uzbrojonych wojowniczek w mundurach obala stereotyp re-

18 Kobani: How strategy, sacrifice and heroizm of Kurdish female fighters beat ISIS, „International Business Times UK” 2015, https://www.ibtimes. co.uk/kobani-how-sacrifice-local-knowledge-heroism-kurdish-female-fighters-beat-isis-1487358.

19 R. Carne, Najbardziej feministyczna rewolucja w historii świata, tłum. Z. Krasowsk, VICE, 28.07.2017.

20 We want revenge: Meet the Yazidi women freeing their sisters from ISIS in Raqqa, „The Independent” 2017 https://www.independent.co.uk/ news/world/middle-east/raqqa-latest-yazidi-women-fighters-ygs-isis-massacre-syria-iraq--a7988461.html. 
presjonowanej muzułmanki ubranej od stóp do głów w burkę, a która sama nie mogła opuścić domu, chyba że w towarzystwie mężczyzny. Kurdyjska opozycja przeciwko IS, reżimowi syryjskiego Assada i Al-Qeada w Syrii wykazał swoje umiejętności i skuteczność od początku konfliktu. Z ich długą historią represji, znajomość taktyk partyzanckich i powiązań w całym reżimie, powinno dziwić, że Kurdowie i YPJ stanowili jedyną prawdziwą przeszkodę dla IS i jego brutalność. Ich wpływ był natychmiast odczuwalny. Zarówno Kurdowie, jak i zachodnie media szybko wykorzystali sukcesy wygranej przez kobiety walki z rebeliantami przeciwko ultra konserwatywnej radykalnej interpretacji islamu.

Ważną rolą kobiecych jednostek YPJ okazał się ich wpływ na morale mężczyzn. Zmotywował ich do większego zaangażowanie się w walki z tzw. Państwem Islamskim. Honor, który odgrywa ważną rolę w tej społeczności, nie pozwalał mężczyznom odmówić udziału i braku zaangażowania w konflikt.

Zmiana modelu społecznego, w społeczeństwie kurdyjskim jak już wcześniej wspomniano stworzyła sytuację, w której mężczyźni walczyli wraz z kobietami. To płeć żeńska mogła dowodzić mieszanym oddziałem. Pozwoliło to na pogłębienie się więzi społecznych między Kurdami. Wspólna walka z brutalnością organizacji terrorystycznej i obrona ludności, a także terytorium, zbudowała silne poczucie jedności i przynależności do danej społeczności. Osoby aktywnie zaangażowane w walki na froncie gotowe były oddać własne życie w imię stawienia oporu tzw. Państwu Islamskiemu. Młode pokolenie Kurdów będących światkiem takiego zjawiska dorośnie w nowym modelu społecznych, reprezentując nowe wartości. Sytuacja, o której mowa doprowadziła do wykreowania się wizerunku kobiety-męczennika. Jak można zauważyć w oficjalnych dokumentach wydawanych przez YPJ, a także analizowanych materiałach video wizerunek ten odgrywa istotną rolę 
w społeczeństwie. Rodziny takich ofiar odbierały ich śmierć z dumą, a męczennicy byli chwaleni poprzez publikację zdjęć, umieszczanie ich wizerunku w miejscach publicznych, a także specjalnej procedurze pochówku ciała. Najsłynniejsze bojowniczki kurdyjskie wielbione były przez młodsze kobiety i stały się dla nich przykładem i motywacją do podjęcia walki.

Ważnym psychologicznym aspektem udziału kobiet w walce z terrorystami z ISIS jest ich model spostrzegania kobiety i jej roli w społeczeństwie. Wypaczony wizerunek doprowadził do obaw śmierci z rąk kobiet. Jeden z kurdyjskich dowódców tłumaczył ten pogląd podczas rozmowy z dziennikarzem z RT: zgodnie z ich filozofią ISIS kobieta nie pełni żadnej roli w społeczeństwie. To dlatego wierzą, że śmierć zadana przez kobietę zamiast do nieba zaprowadzi ich do piekła ${ }^{21}$.

Świadome tego faktu były same Kurdyjki, które poprzez swoje zachowanie oddziaływały psychologicznie. Motywowało je to do walki, a także wykazując dumę z eliminacji islamskich bojowników. Często z otwartością opowiadały o swoich dokonaniach zagranicznej prasie: „Dla bojownika ISIS jedną z najgorszych rzeczy jest śmierć na polu bitwy, także przez kobietę. Wierzyli, że bezpośrednio pójdą do piekła, jeśli zostaną zabici przez kobietę. Dla mnie byłam najszczęśliwszą kobietą, ponieważ mogłem wysłać kilku mężczyzn do piekła"22.

21 A. Wawrzyńczak, Kurdyjki kontra Państwo Islamskie. Jak armia kobiet walczy $z$ dżihadystami?, WP Wiadomości, 2014 https://wiadomosci. wp.pl/kurdyjki-kontra-panstwo-islamskie-jak-armia-kobiet-walczy-z-dzihadystami--6025263569056897a.

22 L. Subramanian, EXCLUSIVE: Kurdish woman fighters are finishing ISIS, smashing patriarchy, „The Week”, 10.01.2020, https://www.theweek. in/news/world/2020/01/10/exclusive-kurdish-woman-fighters-are-finishing-isis-smashing--patriarchy.html. 


\section{Rola wojskowa}

Kurdyjska opozycja przeciwko tzw. Państwu Islamskiemu, reżimowi syryjskiego Assada i Al-Qeada w Syrii wykazała swoje umiejętności i skuteczność od początku konfliktu. Z ich długą historią represji, znajomość taktyk partyzanckich i powiązań w całym reżimie nie powinno dziwić, że Kurdowie i YPJ stanowili jedyną prawdziwą przeszkodę dla wyżej wymienionej organizacji terrorystycznej i jej brutalności. Ich wpływ był natychmiast odczuwalny, zarówno Kurdowie, jak i zachodnie media szybko wykorzystali sukcesy kurdyjskich kobiet w walce $\mathrm{z}$ rebeliantami przeciwko ultra konserwatywnej radykalnej interpretacji islamu.

Państwo Islamskie było coraz większym zagrożeniem dla Bliskiego Wschodu. Ich represyjna natura i pogląd na religię muzułmańską uczyniły ich kulturowo i geopolitycznie niebezpiecznych. Od początku 2017 r. niektóre z najbardziej udanych działań w kierunku pokonanie IS, powstrzymanie postępu i zmuszenie ich do odwrotu były operacjami jednostki kontrpartyzanckiej. W obrębie tych kurdyjskich jednostek były kobiety. Chociaż nie w pełni wykorzystywane, stały w obliczu tych samych zagrożeń, co ich męscy odpowiednicy i miały te same pragnienia walki. Kobiety YPJ udowodniły swoje umiejętności na polu bitwy.

Kurdyjska opozycja przeciwko IS, syryjskiemu reżimowi Assad i AQ w Syrii wykazała się umiejętnościami i skutecznością od początku konfliktu. Z ich długą historią represji, znajomość taktyki partyzanckiej i powiązania w całym reżimie nie powinno dziwić, że Kurdowie stanowili przeszkodę dla rozwoju IS i jego brutalności.

Podczas kampanii wojskowej dla Kobane w 2014 r. YPJ odegrał kluczową rolę w wojskowym oblężeniu miasta i przypisuje 
się im wielkie zwycięstwa. 27 września 2014 r. siły koalicyjne dowodzone przez Stany Zjednoczone rozpoczęły bombardowanie z powietrza, aby wyprowadzić ISIS. Sytuacja szybko przerodziła się w walki uliczne z każdą bojówką, a każdy budynek stał się potencjałem snajpera lub miejsce zasadzki. Między IS a całkowitą kontrolą miasta były Kurdyjscy wojownicy YPG i YPJ. Interesującym faktem jest to, iż obie jednostki dowodzone były przez kurdyjską kobietę - generała Nalina Afrina. Dowiodła ona, że jest najbardziej groźnym przeciwnikiem dla IS. Jej postawa inspiruje zarówno mężczyzn, jak i kobiet cywilnych i wojskowych. Według Syryjskiego Obserwatorium Praw Człowieka (SOHR), kurdyjscy obrońcy w oblężonym mieście Kobani byli współprowadzeni przez 40-letnią Kurdyjkę z regionu Afrin Prowincja Aleppo Mayssa Abdo, znaną przez opinię publiczną jako Narina Afrina ${ }^{23}$.

W dniach od 6 do 15 stycznia 2015 r. doszło do poważnych postępów kurdyjskich w Kobane i do stycznia 2015 r. IS zostało z niego wyparte. Zwycięstwo było najważniejsze - nie tylko dla Kurdów i zachodnich sojuszników, ale ogólnie dla kobiet.

Kurdyjskie kobiece jednostki obronne podjęły współpracę międzynarodową, która polegała między innymi na wspólnej walce na froncie wraz z jednostkami amerykańskimi. Dodatkowym wsparciem kolacji międzynarodowej były treningi Kurdyjek przeprowadzone przez reprezentantów jednostek włoskich, australijskich i kanadyjskich ${ }^{24}$.

23 Kurdish woman leading Kobane battle against IS: activists, Agence France Presse, 2014, https://www.al-monitor.com/pulse/originals/2015/03/ turkey-women-in-middle-east-figen-yuksekdag.html.

24 J. Stocker, Coalition drives to build Iraqi Kurdistan's Peshmerga into a self-sustaining force, The Defense Post, 2019, https://thedefensepost. com/2019/11/27/kurdistan-iraq-coalition-peshmerga-training-ktcc/. 


\section{Konkluzje}

Rola YPJ była ważna, jak i symboliczna dla bojowników oraz zorganizowanej społeczności, a zwłaszcza dla kobiet w regionie Bliskiego Wschodu. Stały się międzynarodowym symbolem feminizmu i otwartego sprzeciwu wobec polityki agresji tzw. Państwa Islamskiego. Ta organizacja terrorystyczna okazała się być wyzwaniem zarówno dla środowiska międzynarodowego, a zwłaszcza całego świata arabskiego. Prowadzona polityka agresji i przemocy wobec kobiet stała się motywacją i inspiracją dla Kurdyjek, które zdecydowały się na podjęcie walki. Udział kobiet w konfliktach zbrojnych nie jest fenomenem, ponieważ w wielu państwach wchodzą one w skład sił zbrojnych, jednakże przypadek YPJ okazał się być symbolem i początkiem przemian w regionie Bliskiego Wschodu.

Należy pamiętać, iż Państwo Islamskie wojnę oparło na ideologii religijnej, w której rola kobiety została zmarginalizowana między innymi do roli niewolnicy seksualnej. Poprzez oddziaływanie na tradycje i wizerunek próbowano zniszczyć wartości danych społeczności. Splamiony honor miał być czynnikiem wywołującym strach i poczucie utraty godności.

Wyżej wymienione elementy okazały się być mobilizacją dla kurdyjskich kobiet tworzących jednostki walczące na froncie. Odegrały one istotną rolę w walce z tzw. Państwem Islamskim. Oprócz sukcesów militarnych dostrzeżonych i docenionych przez środowisko międzynarodowe, znaczącym okazał się wpływ psychologiczny i społeczny. Kobiece Jednostki Obrony podniosły morale kobiet bliskowschodnich. Doprowadziły do rewolucji społecznej, która pozwoliła obalić tradycyjny wizerunek, stawiając bojowniczki na równi z męskimi jednostkami. Wzięły one odpowiedzialność za los prześladowanych mniejszości etnicznych, prowadząc działania mające na celu odbicie 
ich z rąk prześladowców. Stworzyły struktury pozwalające na szkolenia i edukację nie tylko w zakresie umiejętności wojskowych. Ich postawa umocniła poczucie jedności społecznej. Zaangażowanie oraz oddanie sprawie kurdyjskiej wytworzyły wizerunek kobiety-męczennika. Zwycięstwa żeńskich jednostek miały również wpływ psychologiczny na prowadzoną walkę. Osiągnięcia kobiet podważają ekstremistyczne postrzeganie kobiet, którym nie wolno było opuszczać domu bez krewnego mężczyzny. Kurdyjki obaliły również z góry przyjęte zachodnie poglądy na temat Bliskiego Wschodu i muzułmanek.

\section{Bibliografia}

A Road Unforeseen: Woman Fight the Islamic State, „Tax Meredith" 2016.

Arango T., Sunni Extermists in Iraq Seize 3 Towns From Kurds and Threaten Major Dam, „The New York Times” 2014, https://www.nytimes.com/2014/08/04/world/middleeast/ iraq.html.

Argentieri V., Meet the female soldiers in Syria and Iraq fighting for gender equality as much as freedom, "The Telegraph” 2017, https://www.telegraph.co.uk/women/life/meet-female-soldiers-syria-iraq-fighting-gender-equality-much/.

Broke S., "How ISIS Rules”, The New York Review of Books, 2017, https://www.nybooks.com/daily/2014/12/09/how-isis-rules/.

Carner R., The Kurds' Democratic Experiment, „The New York Times" 2015, https://www.nytimes.com/2015/09/30/opinion/the-kurds-democratic-experiment.html.

Carne R., Najbardziej feministyczna rewolucja w historii świata, tłum. Z. Krasowska, VICE, 28.07.2017.

https://www.vice.com/pl/article/xwzbak/najbardziej-feministyczna-rewolucja-w-historii-swiata. 
ISIS „Southern Division” praises foreign suice bom bers, „The Long War Journal" 2014, https://www.longwarjournal.org/ archives/2014/04/isis-southern-division.php.

Knapp M., Revolution in Rojava: Democratic Autonomy and Women's Liberation in Syrian Kurdistan, 2016, https://justicenotchange.files.wordpress.com/2017/09/michael_knapp_ ercan_ayboga_anja_flach_janet_bib-ok-org.pdf.

Kobani: How strategy, sacrifice and heroizm of Kurdish female fighters beat ISIS, International Business Times UK, 2015, https://www.ibtimes.co.uk/kobani-how-sacrifice-local-knowledge-heroism-kurdish-female-fighters-beat-isis-1487358.

Kurdish woman leading Kobane battle against IS: activists, Agence France Presse, 2014, https://news.yahoo.com/kurdish-woman-leading-kobane-battle-against-.

Kurdish women's movement reshapes Turkish politics, Al-Monitor, 2016, https://www.al-monitor.com/pulse/originals/2015/03/turkey-women-in-middle-east-figen-yuksekdag.html.

Official YPJ website, About us, 2019, https://ypjrojava.com/ ypj/en/about-us/.

Roggio B., ISIS announces formation of Caliphate, rebrands as "Islamic State", Long War Journal, 2014, https://www. longwarjournal.org/archives/2014/06/isis_announces_formation_of_ca.php.

Szokująca instrukcja ISIS. Państwo Islamskie radzi, jak sprzedawać, bić i gwatcić niewolnice, „Polska Times” 2015, https://polskatimes.pl/szokujaca-instrukcja-isis-panstwo-islamskie-radzi-jak-sprzedawac-bic-i-gwalcic-niewolnice/ ar/3684422.

Subramanian L., EXCLUSIVE: Kurdish woman fighters are finishing ISIS, smashing patriarchy, „The Week”, 10.01.2020, https://www.theweek.in/news/world/2020/01/10/exclusi- 
ve-kurdish-woman-fighters-are-finishing-isis-smashing-patriarchy.html.

Stocker J., Coalition drives to build Iraqi Kurdistan's Peshmerga into a self-sustaining force, The Defense Post, 2019, https://thedefensepost.com/2019/11/27/kurdistan-iraq-coalition-peshmerga-training-ktcc/.

Syria's civil war explained from beginning, Al-Jazeera, 2017, https://www.aljazeera.com/news/2016/05/syria-civil-war-explained-160505084119966.html.

Syrian Troops Open on Protestors in Several Cities, „The New York Times" 2011, https://www.nytimes.com/2011/03/26/ world/middleeast/26syria.html.

The Soufan Group, The Islamic State, November 2014, https:// thesoufancenter.org/wp-content/uploads/2017/11/Beyond-the-.

Wawrzyńczak A., Kurdyjki kontra Państwo Islamskie. Jak armia kobiet walczy $z$ dzihadystami?, WP Wiadomości, 2014, https://wiadomosci.wp.pl/kurdyjki-kontra-panstwo-islamskie-jak-armia-kobiet-walczy-z-dzihadystami-6025 263569056897a.

We want revenge: Meet the Yazidi women freeing their sisters from ISIS in Raqqa, „The Independent” 2017, https://www. independent.co.uk/news/world/middle-east/raqqa-latest-yazidi-women-fighters-ygs-isis-massacre-syria-iraq-a7988461.html.

We are Plan C, Jin, Jiyan, Azadi! Exeriences from the UK's first Jineology camp, 2019, https://www.weareplanc.org/blog/ jin-jiyan-azadi-experiences-from-the-uks-first-jineologycamp/.

Varghese J., ISIS Threat: Kurdish Forces Rescue 10,000 Yazidis from Sinjar Mountains, International Business Times, 2014. 


\begin{abstract}
Abstrakt
Poniższa analiza przedstawia rolę kurdyjskich jednostek kobiecych w walce z tak zwanym Państwem Islamskim. Przedstawione są trzy najważniejsze zdaniem autora aspekty: wojskowy, społeczny i psychologiczny. YPJ odniosło sukcesy podczas walk z wyżej wymienioną organizacją terrorystyczną, tym samym zwracając uwagę środowiska międzynarodowego na swoje dokonania, budując nowy wizerunek kobiety na Bliskim Wschodzie. Analiza pokazuje, iż Kurdyjki dokonały rewolucji kobiecej w społeczności kurdyjskiej stawiając sylwetkę kobiety na równi z mężczyzną. Sytuacja ta odmieniła postrzeganie tej płci jako zamkniętej w domu z zmarginalizowanymi prawami. Ich zaangażowanie i determinacja pozwoliły na równą walkę z ISIS. Poniższy tekst ukazuje czynniki odgrywające istotną rolę w eliminacji działalności brutalnej organizacji terrorystycznej i zatrzymanie jej ekspansji terytorialnej na terenach Syrii i Iraku.
\end{abstract}

Słowa kluczowe: Państwo Islamskie, Kurdyjskie Jednostki Obronne, rewolucja kobieca, Bliski Wschód, YPJ

\begin{abstract}
The following analysis presents the role of Kurdish women's units in the fight against the so-called Islamic State. According to the author, the three most important aspects are: military, social and psychological. YPJ has been successful in fighting the above-mentioned terrorist organization, thus drawing the international community's attention to its achievements, building a new image of a woman in the Middle East. The analysis shows that Kurdish women made a revolution in the Kurdish community putting the figure of a woman on a par with a man. This situation changed the perception of this sex as locked in a house with marginalized rights. Their commitment and determination allowed for an equal fight against ISIS. The following text shows the factors that play an important role in eliminating the activities of a violent terrorist organization and stopping its territorial expansion in Syria and Iraq.
\end{abstract}

Keywords: Middle East, YPJ, Islamic State, women`s resolution, Women's Protection Units 


\section{Grażyna Strnad}

Uniwersytet im. Adama Mickiewicza w Poznaniu

ORCID ID: https://orcid.org/0000-0001-5774-4543

\section{Szczyty międzykoreańskie w okresie prezydentury Moon Jae Ina}

Rok 2018 był dla stosunków międzykoreańskich wyjątkowy. Uczestnictwo Korei Północnej w Zimowych Igrzyskach Olimpijskich w południowokoreańskim Pjongczangu było wydarzeniem przełomowym ${ }^{1}$. Był to wielkim sukces dyplomatyczny Seulu i Pjongjangu. Korea Południowa wyszła z inicjatywą i zaprosiła sąsiada z Północy do wzięcia udziału w rywalizacji sportowej. Do Pjongczangu przybyła 500-osobowa reprezentacja Korei Północnej. W północnokoreańskiej reprezentacji znaleźli się sportowcy, trenerzy, kibice, a także żeński zespół artystyczny (północnokoreańskie cheerleaderki). Największe znaczenie miała jednak obecność wysokich rangą przedstawicieli władz państwowych: Kim Yong Nama (przewodniczącego Prezydium Najwyższego Zgromadzenia Ludowego KRLD) oraz Kim Yo Dzong (siostry Kim Dzong Una). Po raz pierwszy od czasu utworzenia dwóch państw koreańskich (w 1948 r.), członek rodziny rządzącej w Korei Północnej odwiedził Korę Południowąa 2 .

1 W styczniu 2018 r. Międzynarodowy Komitet Olimpijski wydał zgodę na udział Korei Północnej w Igrzyskach Olimpijskich w Pjongczangu. Zatwierdził również udział 22 północnokoreańskich sportowców w olimpiadzie, w tym wystawienie jednej drużyny koreańskiej w hokeju kobiet. Komitet Olimpijski wydał również zgodę na przemarsz reprezentacji zawodników obu Korei podczas ceremonii otwarcia pod jedną flagą - „flagą zjednoczeniową".

2 G. Strnad, Olimpijska dyplomacja na Pótwyspie Koreańskim - Pjon- 
W styczniu 2018 r. w noworocznym orędziu Kim Dzong Un, północnokoreański przywódca uroczyście oświadczył, że: „[...] Ten rok jest rokiem znaczącym zarówno dla Północy, jak i Południa Korei, ponieważ nasi ludzie świętować będą 70 . rocznicę powstania KRLD, jako wspaniałe pomyślne wydarzenie, na południu zaś odbędą się Zimowe Igrzyska Olimpijskie. Aby uroczyście przeprowadzić te wielkie narodowe wydarzenie oraz zademonstrować godność i siłę narodu, powinniśmy odmrozić zamrożone relacje i w ten sposób uczcić ten znaczący rok, jako rok, który szczególnie zapisze się w historii narodu. [...]”3. Ponadto „Towarzysz Kim Jong Un, przewodniczący Komisji Spraw Państwowych Koreańskiej Republiki Ludowo-Demokratycznej, po otrzymaniu raportu o tym, że południowokoreański Błękitny Dom oficjalnie poparł i z zadowoleniem przyjął jego stanowisko wobec udziału w Igrzyskach Olimpijskich w Pjongczangu i poprawy stosunków między Koreą Północną i Południową zawarte w Noworocznym Orędziu oraz że na pierwszym posiedzeniu rady państwa $\mathrm{w}$ dniu 2 stycznia Prezydent Mun Jae In osobiście zadeklarował swoje aktywne poparcie i poinstruował odpowiednie organy by podjęły istotne działania w tym celu"4.

Spotkanie koreańskich elit Południa i Północy odbyło się dzięki dyplomatycznemu zaangażowaniu wielu stron. Co więcej, po raz pierwszy w historii zimowych i letnich olimpiad, dwie Koree zdecydowały o wystawieniu jednej drużyny sportowej w hokeju kobiet. W jej skład weszło 35 zawodniczek (23 Koreanek z Południa i 12 Koreanek z Północy). Warto w tym miejscu przypomnieć, że dokładnie trzydzieści jeden lat temu w $1988 \mathrm{r}$.

gczang 2018, [w:] Wspótpraca i rywalizacja państw azjatyckich, red. J. Marszałek-Kawa, J. Zajączkowski, Toruń 2018, s. 144-145.

3 W.J. Dziak, Anatomia władzy totalnej. Przypadek Korei Północnej, Warszawa 2018, s. 156.

4 Ibidem, s. 158-159. 
w Seulu odbyły się letnie Igrzyska Olimpijskie. Jednakże prowadzone wówczas wielostronne rozmowy z Koreą Północną na temat jej uczestnictwa w organizacji olimpiady zakończyły się fiaskiem.

W 2018 r. pojawiła się kolejna szansa na przełom w stosunkach dwustronnych między Koreą Północną a Koreą Południową. W swoim noworocznym orędziu północnokoreański przywódca Kim Dzong Un zadeklarował powrót do rozmów z Seulem. Warto w tym miejscu przypomnieć, że od $1953 \mathrm{r}$. państwa koreańskie znajdują się w stanie wojny. Na przestrzeni lat stosunki między dwoma Koreami charakteryzowały się wrogością i konfrontacją. Jednak władze w Pjongjangu i w Seulu prowadziły wielokrotnie także negocjacje ukierunkowane na unormowanie napiętej sytuacji oraz podejmowały działania w celu nawiązania pokojowego dialogu na Półwyspie Koreańskim. W okresie od kwietnia do września 2018 r. odbyły się trzy międzykoreańskie szczyty: w Panmundżom 27 kwietnia i 26 maja oraz w Pjongjangu 18-20 września.

Dialog i działania na rzecz podpisania pokoju z Koreą Północą to wielka misja południowokoreańskiego prezydenta Moon Jae Ina, który od początku swojej prezydentury dąży do realizacji polityki pojednania z Koreą Północną. Deklarował także swoją pełną gotowość do rozmów oraz spotkań na szczycie z Waszyngtonem, Pekinem, Tokio oraz Pjongjangiem. Prezydent Moon podkreślał również, że rozwiązywanie problemów politycznych Półwyspu Koreańskiego powinno odbywać się pod południowokoreańskim przywództwem we współpracy z innymi państwami, przede wszystkim ze Stanami Zjednoczonymi, Chinami, Rosją i Japonią.

Polityka międzykoreańska prezydenta Moon Jae Ina nawiązuje do okresu progresywnych rządów prezydenta Kim Dae Junga i Roh Moo Hyuna. Zapoczątkowana przez Kim Dae Junga Polityka Słonecznego Blasku była punktem zwrotnym w po- 
łudniowokoreańskiej polityce wobec Korei Północnej. Głównym celem „słonecznej” strategii Seulu wobec Pjongjangu była poprawa stosunków międzykoreańskich przez działanie na rzecz pojednania narodowego, współpracy i ustanowienia pokoju 5 .

Przyjęta przez administrację Kim Dae Junga południowokoreańska polityka wobec Korei Północnej zakładała przede wszystkim zaangażowanie, pojednanie i współpracę międzykoreańską ${ }^{6}$. Polityka Słonecznego Blasku ukierunkowana była nie na natychmiastowe zjednoczenie Korei, ale na pokojową koegzystencję dwóch państw koreańskich. W tym czasie wielu analityków błędnie spodziewało się, że zjednoczenie nastąpi przez wchłonięcie pogrążonej w kryzysie gospodarczym i żywnościowym Korei Północnej. Administracja Kim Dae Junga uważała jednak, że Korea Południowa powinna odegrać znaczącą rolę w rozwiązaniu układu zimnowojennego i doprowadzić do ustanowienia trwałego pokoju i stabilności na Półwyspie Koreańskim. W celu zrealizowania swojej polityki Kim Dae Jung dążył do zmiany negatywnego nastawienia południowokoreańskiego społeczeństwa wobec północnego sąsiada, utrwalonego przez autorytarne rządy wojskowe. Wrogie postrzeganie Korei Północnej zastąpić miał wizerunek „północnokoreańskiego brata", partnera negocjacji i dialogu?

W okresie rządów Kim Dae Junga doszło do historycznego, pierwszego spotkania na szczycie między przywódcami Południa i Północy. W dniach 13-15 czerwca 2000 r. uwaga

5 G. Strnad, Olimpijska dyplomacja..., op.cit., s. 152-153.

6 Dae Jung Kim, The Government of the People: Reconciliation and a New Leap Forward, Seoul, 25 February 1998, „Korea and World Affairs” 1998, vol. 22, nr 1, s. 93-99; Soonyoung Hong, Thawing Korea's Cold War: The Path to Peace on the Korean Peninsula, „Foreign Affairs” 1999, vol. 78, nr 3, s. 10.

7 Ministry of Unification, Policy towards North Korea for Peace, Reconciliation, and Cooperation, Ministry of Unification, Seoul 1999, s. 1-28. 
międzynarodowej społeczności skierowała się na Półwysep Koreański. Najważniejszym osiągnięciem spotkania na szczycie była Wspólna Deklaracja Południa i Północy, która została zawarta 15 czerwca 2000 r. przez Kim Dae Junga, prezydenta Republiki Korei i Kim Dzong Ila, przewodniczącego Komisji Obrony Narodowej Koreańskiej Republiki Ludowo-Demokratycznej.

Kolejny prezydent Korei Południowej, Roh Moo Hyun, kontynuował politykę zaangażowania wobec Korei Północnej, zapoczątkowaną przez prezydenta Kim Dae Junga. W trakcie kampanii prezydenckiej w 2002 r. Roh podkreślał, że pojednanie Seulu z Pjongjangiem jest jego priorytetem. Powiedział wówczas: „Nie przejmowałbym się porażkami w innych kwestiach politycznych, oby tylko polityka w stosunku do Korei

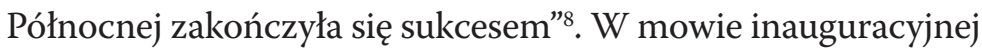
wygłoszonej 25 lutego 2003 r. prezydent Roh przedstawił Politykę Pokoju i Dobrobytu jako wszechstronną, długoterminową strategię rozwoju narodowego ukierunkowaną na zapewnienie pokoju na Półwyspie Koreańskim oraz osiągnięcie obustronnego dobrobytu przez Koreą Południową i Koreą Północną. Podkreślał również potrzebę dialogu w rozwiązaniu północnokoreańskiego kryzysu atomowego i ustanowienia trwałego pokoju na Półwyspie, jako ważnego elementu stabilności w regionie Azji Północno-Wschodniej ${ }^{9}$.

Polityka Pokoju i Dobrobytu nie była jedynie kontynuacją Polityki Słonecznego Blasku. W swoich założeniach zakładała bowiem zwiększenie wymiany i współpracy międzykoreań-

8 Choong Nam Kim, The Roh Moo Hyun Government's Policy toward North Korea, „International Journal of Korean Studies” 2005, vol. 9, nr 2, S. 14.

9 Roh Moo Hyun, President Roh Moo Hyun's Inaugural Address, „Korea and World Affairs" 2003, vol. 27, nr 1, s. 115-116; Kang In-duk, Toward Peace and Prosperity: The New Government's North Korea Policy, „East Asian Review" 2003, vol. 15, nr 1, s. 3-4. 
skiej, wspieranie pokoju na Półwyspie Koreańskim, dążenie do wspólnego dobrobytu obu Korei w celu położenia fundamentów pod pokojowe zjednoczenie, co miało także uczynić Koreę Południową gospodarczym centrum Azji Północno-Wschodniej. Oznaczało to, iż administracja Roha nie tylko promowała pokój i dobrobyt w kontekście międzykoreańskiego pojednania, ale również otwarta była na współpracę w zakresie gospodarki i bezpieczeństwa z innym państwami regionu Azji Północno-Wschodniej, szczególnie z Chinami i Rosją ${ }^{10}$.

Pod koniec kadencji prezydenta Roh Moo Hyuna w październiku 2007 r. doszło do drugiego spotkania na szczycie. Najważniejszym osiągnięciem spotkania przywódców koreańskich było przyjęcie Deklaracji o rozwoju stosunków między Południem a Północą, pokoju i dobrobycie. W wyniku spotkania przywódców w Pjongjangu i podpisania Deklaracji ostatnie miesiące 2007 r. wypełnione były licznymi kontaktami między dwoma Koreami. Wielu obserwatorów uważało, że był to okres najbardziej intensywnych i znaczących relacji między Południem a Północą w historii dialogu międzykoreańskiego. Wydawało się, że zaczął się okres nieodwracalnie prowadzący do pojednania między Seulem a Pjongjangiem ${ }^{11}$.

Południowokoreańska polityka zaangażowania wobec Korei Północnej w okresie administracji Roh Moo Hyuna polegała na różnych formach współpracy i wymiany międzykoreańskiej, a także na udzielanej przez Koreę Południową pomocy humanitarnej. Sztandarowymi projektami międzykoreańskiej współpracy realizowanym za rządów administracji Roha były kompleks

10 G. Strnad, Korea. Polityka Południa wobec Pótnocy w latach 1948-2008. Zmiana i kontynuacja, Poznań 2014, s. 450-451.

11 A. Foster-Carter, North Korea-South Korea Relations: Sunshine Deepened, only to Dim?, „Comparative Connections” 2008, vol. 9, nr. 4, s. 12, http://csis.org/files/media/csis/ pubs/0704qnk_sk.pdf [dostęp: 12.09.2019]. 
przemysłowy Kaesŏng oraz region turystyczny w Górach Diamentowych ${ }^{12}$.

Polityka Pokoju i Dobrobytu miała zmniejszyć napięcie na Półwyspie Koreańskim, przełamać wzajemną nieufność i doprowadzić do pojednania z Koreą Północną na drodze dialogu i negocjacji. Koniec rządów administracji Roh Moo Hyuna oznaczał jednocześnie zakończenie polityki progresywnej, u podstaw której leżało bezwarunkowe wsparcie Korei Północnej, oddzielenie spraw politycznych od gospodarczych.

Stanowisko obejmującego w lutym 2008 r. urząd prezydenta Lee Myung Baka wobec Korei Północnej różniło się diametralnie od poprzednich dwóch administracji. W rezultacie konserwatywnej polityki nowego rządu nastąpiło odejście od bezwarunkowej współpracy i pomocy gospodarczej, a dialog polityczny między Południem a Północą ponownie stanął pod znakiem zapytania. Kolejne konserwatywne rządy prezydenta Park Geun Hye także wprowadziły w stosunkach międzykoreańskich podejście umiarkowane wobec Korei Północnej.

W maju 2017 r. wraz z wygraną w wyborach prezydenckich Moon Jae Ina nastąpił powrót do polityki progresywnej, ukierunkowanej na wznowienie dialogu z Koreą Północną. Moon był szefem gabinetu i sekretarzem stanu w rządzie Roh Moo Hyuna. Spotkanie w Pjongczangu delegacji północnokoreańskiej z przedstawicielami z Korei Południowej stało się znaczącym wydarzeniem 2018 r. i kolejnym krokiem na rzecz ocieplenia stosunków międzykoreańskich. Ponadto podczas olimpiady siostra północnokoreańskiego przywódcy przekazała prezydentowi Moonowi zaproszenie do Pjongjangu. Po zakończeniu igrzysk,

12 W okresie dynastii Koryo (918-1392) miasto Kaesong (dawna nazwa Songak) było stolicą państwa koreańskiego. Strefa ekonomiczna Kaesong znajduje się ok. 58 kilometrów na północ od Seulu, ok. 137 km od Pjongjangu oraz ok. 8 kilometrów od strefy zdemilitaryzowanej w Panmundżom, ok. 60 kilometrów od Inchon. 
w marcu miało miejsce spotkanie delegacji południowokoreańskiej z Kim Dzong Unem. Kim otrzymał wówczas osobisty list od prezydenta Moona. Strona północnokoreańska uznała to spotkanie za wyraz poprawy stosunków na linii Północ-Południe. Należy również podkreślić, że Kim Dzong Un podczas spotkania z delegacją południowokoreańską zadeklarował wolę pokojowego rozwiązania problemu nuklearnego. Północnokoreański przywódca wyraził chęć podjęcia rozmów na ten temat pod warunkiem otrzymania gwarancji bezpieczeństwa. Po powrocie do Seulu, delegacja południowokoreańska na czele z jej głównym emisariuszem Chung Eui Yongiem przekazała informację, że władze Korei Północnej zamierzają zamrozić testy nuklearne i rakietowe, wyrażając w ten sposób gotowość do rozmów na temat denuklearyzacji oraz zgodziły się po latach na zorganizowanie kolejnego szczytu międzykoreańskiego

Szczyt międzykoreański, który odbył się 27 kwietnia 2018 r. przywrócił kontakty między państwami koreańskimi na najwyższym szczeblu. Był to trzeci z kolei szczyt koreańskich przywódców Południa i Północy - Moon Jae Ina i Kim Dzong Una. Spotkanie miało miejsce w południowej części strefy zdemilitaryzowanej w Panmundżom. Kim Dzong Un jest pierwszym północnokoreańskim przywódcą, który złożył dyplomatyczną wizytę w Korei Południowej. W Domu Pokoju, w księdze gości napisał, że wraz z tym spotkaniem rozpoczyna się nowa historia, era pokoju ${ }^{13}$. Koreańscy przywódcy zadeklarowali, że nie będzie więcej wojny na Półwyspie Koreańskim.

W podpisanej przez koreańskich przywódców deklaracji Panmundżom (Deklaracji na rzecz pokoju, dobrobytu i zjednoczenia Półwyspu Koreańskiego) znalazły się trzy wspólne inicjatywy. Po pierwsze, strony zapowiedziały poprawę wza-

13 R. Stefanicki, Szczyt koreańskich uśmiechów. „Rozpoczyna się nowa historia, era pokoju”, http://wyborcza.pl/7,75399,23330185,szczyt-koreanskich-usmiechow-rozpoczyna-sie-nowa-historia.html [dostęp: 12.09.2019]. 
jemnych stosunków, podkreślając, że zjednoczenie narodowe Koreańczyków jest sprawą międzykoreańską. Ustanowiono, że zostanie utworzone w północnokoreańskim Kaesongu biuro łącznikowe w celu ponownego nawiązania wzajemnych kontaktów. Zadeklarowano wznowienie współpracy kulturalnej i spotkań członków rozdzielonych rodzin. W tym celu zapowiedziano także zmodernizowanie połączeń drogowych i kolejowych między obydwoma państwami. Po drugie, zadeklarowano, że strony zaprzestaną wrogich działań propagandowych oraz podejmą regularny dialog między wojskowymi. Po trzecie, liderzy dwóch państw koreańskich zadeklarowali podjęcie działań na rzecz ustanowienia trwałego pokoju, podpisania traktatu pokojowego kończącego wojnę koreańską, a także osiągnięcia pełnej denuklearyzacji na Półwyspie Koreańskim we współpracy ze społecznością międzynarodową ${ }^{14}$. Na jesień strony zaplanowały kolejne spotkanie, wizytę prezydenta Moona w Pjongjangu.

W 2018 r. zapowiadany był również inny ważny dla stosunków międzykoreańskich szczyt w Singapurze. Planowano spotkanie amerykańskiego prezydenta Donalda Trumpa z północnokoreańskim przywódcą Kim Dzong Unem. Jednakże Trump niespodziewanie odwołał spotkanie z Kimem, tłumacząc swoją decyzję wrogim oświadczeniem Pjongjangu wobec Waszyngtonu. W takich okolicznościach doszło do kolejnego spotkania przywódców koreańskich. Interwencja dyplomatyczna prezydenta Moon Jae Ina, która odbyła się w Panmundżom 26 maja 2018 r., doprowadziła do wznowienia rozmów amerykańsko-północnokoreańskich. Pozwoliło to na zorganizowanie zaplanowanego na 12 czerwca szczytu przywódców Stanów Zjednoczonych i Korei Północnej. Podczas spotkania w Sin-

14 C. Knight, The Inter-Korean Summit Declaration of April 27, 2018: a review in detail, http://www.comw.org/pda/fulltext/180427\%20Panmunjeom\%20Summit\%20Declaration\%20-\%20review.pdf [dostęp: 12.09.2019]. 
gapurze doszło do spotkania trzech sojuszników. Omówiono wówczas zasady współpracy na rzecz rozwiązania problemu północnokoreańskich zbrojeń. Ministrowie obrony Korei Południowej Jeong Kyeong-doo, Stanów Zjednoczonych Patrick Shanahan oraz Japonii Iwaya Takeshi wyrazili wolę współpracy w celu osiągnięcia całkowitej i weryfikowalnej denuklearyzacji KRLD oraz ustanowienia trwałego pokoju na Półwyspie Koreańskim $^{15}$.

Spotkanie w Singapurze przywódców USA i Korei Północnej zaowocowało podpisaniem wspólnego oświadczenia. Kim Dzong Un zobowiązał się do działań na rzecz całkowitej denuklearyzacji Półwyspu Koreańskiego, z kolei prezydent Donald Trump zapowiedział udzielenie Korei Północnej gwarancji bezpieczeństwa. W treści oświadczenia nie określono jednak, o jakie gwarancje chodzi, nie ustalono także konkretnego harmonogramu likwidacji północnokoreańskiego arsenału jądrowego. Prezydent Trump nazwał dokument „bardzo ważnym” i „wszechstronnym”, z kolei północnokoreański przywódca zapowiedział, że „świat zobaczy poważną zmianę"16.

Kolejny szczyt międzykoreański odbył się w dniach 18-20 września w Pjongjangu. Po raz trzeci w 2018 r. spotkali się koreańscy przywódcy: Kim Dzong Un i Moon Jae-in. Od czasu kwietniowego spotkania przywódców miała miejsce intensyfikacja kontaktów między dwoma Koreami. Strony realizowały podjęte deklaracje: odbywała się międzykoreańska wymiana kulturalna, doszło do spotkania rodzin rozdzielonych w wyniku wojny koreańskiej, prowadzono rozmowy między delegacjami sił zbrojnych. Na kilka dni przed szczytem otwarto w Kaesongu biuro łącznikowe w celu nawiązania kontaktów przez przedstawicieli obu Korei.

15 N. Pkhaladze, The 2018 Singapore Summit: A Milestone towards Solution to the Korean Crisis, "Policy Brief” 2018, s. 4.

16 Ibidem, s. 5-6. 
Najważniejszym osiągnięciem wrześniowego szczytu jest przyjęcie deklaracji z Pjongjangu ${ }^{17}$ i zawarcie porozumienia na szczeblu ministerstw obrony na rzecz budowy zaufania i bezpieczeństwa. W podpisanych dokumentach strony zapowiedziały zredukowanie napięć militarnych na granicy 38 równoleżnika. Tematem rozmów koreańskich przywódców była stopniowa realizacja deklaracji z Panmundżom.

Strony postanowiły działać na rzecz współpracy rozbrojeniowej, rozwoju dróg kolejowych, współpracy gospodarczej, przekształcenia strefy zdemilitaryzowanej w strefę pokojową, a także zainteresowane są kontynuacją łączenia rozdzielonych rodzin. Zarówno Pjongjang, jak i Seul są nastawieni na kontynuowanie dialogu. Szczególnie ważnym obszarem, który powinien stać się fundamentem zbliżenia dwóch Korei, pozostaje międzykoreańska współpraca gospodarcza. Przez wiele lat jej symbolem była specjalna strefa ekonomiczna w Kaesong w Korei Północnej, którą zamknięto w lutym 2016 r. z powodu ochłodzenia stosunków między Seulem i Pjongjangiem. Ważne jest także ponowne uruchomienie strefy turystycznej w Górach Diamentowych. Były to najbardziej spektakularne osiągnięcia współpracy międzykoreańskiej.

We wspólnej deklaracji z Pjongjangu Moon Jae In i Kim Dzong Un potwierdzili swoje zobowiązania dotyczące denuklearyzacji Półwyspu Koreańskiego. Przywódca Korei Północnej wyraził także wolę zlikwidowania ośrodka badań i testów rakietowych, a także wyrzutni rakietowej w Tongchang-ri. Ponadto zaproponował ostateczne zlikwidowanie instalacji nuklearnych w najbardziej znanym północnokoreańskim obiekcie jądrowym w Yongbyon w zamian za „pewne ustępstwa” ze strony Stanów Zjednoczonych. Liderzy obu Korei zgodzili się

17 Więcej na ten temat: Koreatimes, https://www.koreatimes.co.kr/ www/nation/2018/09/103_255848.html [dostęp: 12.09.2019]. 
dodatkowo na podjęcie działań na rzecz zostania gospodarzami Letnich Igrzysk Olimpijskich w 2032 r. Utrzymaniu dialogu międzykoreańskiego na najwyższym szczeblu ma służyć także zapowiedziana wizyta północnokoreańskiego przywódcy w Seulu. Oznacza to, że jednym z największych wyzwań stojących przed polityką administracji Moon Jae Ina niezmiennie pozostają stosunki międzykoreańskie.

\section{Bibliografia}

Dziak W.J., Anatomia władzy totalnej. Przypadek Korei Pótnocnej, Warszawa 2018.

Foster-Carter A, North Korea-South Korea Relations: Sunshine Deepened, only to Dim?, "Comparative Connections”, 2008, vol. 9, nr 4, http://csis.org/files/media/csis/ pubs/0704qnk_ sk.pdf.

Hong Soonyoung, Thawing Korea's Cold War: The Path to Peace on the Korean Peninsula, „Foreign Affairs” 1999, vol. 78 , nr 3.

Kim Dae Jung, The Government of the People: Reconciliation and a New Leap Forward, Seoul, 25 February 1998, „Korea and World Affairs" 1998, vol. 22, nr 1.

Koreatimes, https://www.koreatimes.co.kr/www/nation/2018 /09/103_255848.html.

Kang In-duk, Toward Peace and Prosperity: The New Government's North Korea Policy, „East Asian Review” 2003, vol. $15, \mathrm{nr} 1$.

Kim Choong Nam, The Roh Moo Hyun Government's Policy toward North Korea, „International Journal of Korean Studies" 2005, vol. 9, nr 2.

Knight C., The Inter-Korean Summit Declaration of April 27, 2018: a review in detail, http://www.comw.org/pda/ 
fulltext/180427\%20Panmunjeom\%20Summit\%20Declaration\%20-\%20review.pdf.

Ministry of Unification, Policy towards North Korea for Peace, Reconciliation, and Cooperation, Seoul 1999.

Roh Moo Hyun, President Roh Moo Hyun's Inaugural Address, „Korea and World Affairs” 2003, vol. 27, nr 1.

Pkhaladze N., The 2018 Singapore Summit: A Milestone towards Solution to the Korean Crisis, „Policy Brief” 2018.

Stefanicki R., Szczyt koreańskich uśmiechów. „Rozpoczyna się nowa historia, era pokoju", http://wyborcza.pl/7,75399,2333 0185,szczyt-koreanskich-usmiechow-rozpoczyna-sie-nowa-historia.html.

Strnad G., Korea. Polityka Potudnia wobec Pótnocy w latach 1948-2008. Zmiana i kontynuacja, Poznań 2014.

Strnad G., Olimpijska dyplomacja na Pótwyspie Koreańskim - Pjongczang 2018, [w:] Wspótpraca i rywalizacja państw azjatyckich, red. J. Marszałek-Kawa, J. Zajączkowski, Toruń 2018.

\section{Abstrakt}

Udział Korei Północnej w Zimowych Igrzyskach Olimpijskich w południowokoreańskim Pjongczangu w 2018 r. stał się momentem przełomowym w ociepleniu stosunków międzykoreańskich. W okresie od kwietnia do września odbyły się trzy szczyty międzykoreańskie. Podczas nich spotkali się w Panmundżom, a następnie w Pjongjangu koreańscy przywódcy: Moon Jae In i Kim Dzong Un. Spotkania te zakończyły się wspólnymi deklaracjami stron. Wśród najważniejszych zapisów znajdują się: działania na rzecz pokoju, kontynuowanie rozmów na temat podpisania traktatu pokojowego, zmniejszenie napięcia militarnego oraz denuklearyzacja, które pozostają priorytetowymi celami obu państw Półwyspu Koreańskiego.

Słowa kluczowe: stosunki międzykoreańskie, Moon Jae In, Kim Dae Dzung, Roh Moo Hyun, denuklearyzacja 


\begin{abstract}
North Korea's participation in the Winter Olympic Games, hosted by South Korea in 2018, became a turning point in the warming of inter-Korean relations. In the period from April to September 2018 three inter-Korean summits took place. During the summits the Korean leaders, Moon Jae In and Kim Dzong Un, met twice at Panmunjom, and then once in Pyongyang. These meetings ended with both parties signing joint declarations. The most important provisions included: activities for peace, continuation of talks on the signing of a peace treaty, reduction of military tension and denuclearization, all of which are identified by the two nation-states of the Korean Peninsula as being priority goals.
\end{abstract}

Keywords: inter-Korean relations, Moon Jae In, Kim Dae Jung, Roh Moo Hyun, denuclearization 


\title{
Jacek Knopek
}

\author{
Uniwersytet Mikołaja Kopernika w Toruniu \\ ORCID ID: https://orcid.org/0000-0002-9878-5808
}

\section{Polacy w przestrzeni cywilizacyjnej Półwyspu Arabskiego}

Powszechnie spotkać można opinie publicystyczne i naukowe, iż Polacy znaleźli się na wszystkich zamieszkałych przez człowieka kontynentach świata. Wpływ na taki stan miały dynamicznie rozwijające się wydarzenia związane z dziejami państwa i narodu polskiego, a także nowożytna i najnowsza historia świata, której towarzyszyła rewolucja przemysłowa, wzmożone procesy migracyjne, wojny i konflikty zbrojne, a także zwykła ludzka ciekawość, polegająca na chęci poznania innych kultur i regionów. Dzięki takim zjawiskom o emigracji polskiej i Polonii mówić i pisać możemy w odniesieniu do poszczególnych krajów i regionów świata. Wśród tych ostatnich występują takie, które położone są peryferyjnie względem centrów decyzyjnych świata.

O ile większe skupiska polskie i polonijne były i są w literaturze przedmiotu sukcesywnie badane i analizowane, o tyle świat arabski był często pomijany. Dotychczas nie ukazała się synteza książkowa, która omawiałaby napływ, rolę i działalność Polaków w tej części świata ${ }^{1}$. Tzw. świat arabski był i jest

1 W literaturze przedmiotu spotkać można opracowania cząstkowe, odnoszące się do poszczególnych państw i regionów należących do tzw. kultury arabskiej. Dla Afryki Północnej takim punktem wyjścia byłaby pozycja Jacka Knopka, Migracje Polaków do Afryki Pótnocnej w XX wieku, Bydgoszcz 2001. Historyczny obraz migracji podejmowanych przez Polaków do Egiptu dał Hieronim Kaczmarek: Polacy w Egipcie do 1914 roku, Szczecin 2008. Na temat historycznych kontaktów Polaków z regionem bliskowschodnim zob. 
zróżnicowany pod względem geograficznym, politycznym, ekonomicznym, narodowym czy kulturowym. W odniesieniu do stosunków międzynarodowych wyróżnić można w jego strukturze kilka regionów. Jednakże jego „jądro” od początku było silnie powiązane z Półwyspem Arabskim i takie pozostało do współczesności. Stąd też celem niniejszego artykułu stało się przedstawienie roli i działalności Polaków w tej konkretnej części świata arabskiego. Ukazano ją co prawda w toku procesu historycznego, jednakże dopiero ostatnie dekady zadecydowały o powstaniu na tym obszarze zbiorowości polskich i polonijnych.

Określając politycznie i geograficznie Półwysep Arabski miano na uwadze Arabię Saudyjską, Bahrajn, Jemen (po II wojnie światowej występował tam Jemen Południowy i Jemen Północny), Katar, Oman oraz Zjednoczone Emiraty Arabskie. Co prawda arabskie podmioty prawnomiędzynarodowe powstawały głównie po II wojnie światowej, jednakże ich nazwy regionalne występowały znacznie wcześniej. Określając zatem chronologię badań odwołano się w tym względzie do anachronizmu polegającego na tym, że współczesne granice państw arabskich wyznaczają oblicza historycznego świata arabskiego.

Artykuł ma charakter syntetyzujący, co oznacza, iż wskazano w nim na główne ogniwa relacji łączących ludność polską z Półwyspem Arabskim. Związki te wiązać należy z dokonującymi się procesami migracyjnymi w Polsce i świecie, co znalazło odzwierciedlenie w niniejszym studium. Napływ Polaków na Półwysep Arabski, mimo że kształtowany w warunkach specyficznych, swą formą i treścią nawiązywał do podstawo-

J.S. Bystroń, Polacy w Ziemi Świętej, Syrji i Egipcie 1147-1914, Kraków 1929; S. Kościałkowski, Polacy a Liban i Syria w toku dziejowym, Bejrut 1949; S.A. Korwin (Pawłowski), Stosunki Polski z Ziemia Święta, przedm. J. Mitkowski, Warszawa 1958. Obecność Polaków w Arabii Saudyjskiej zobrazowała w pierwszej dekadzie XXI w. Agnieszka Bakalarz, Polaków odkrywanie Arabii Saudyjskiej, Kraków 2005. 
wych typologii migracyjnych ${ }^{2}$. Miały one także odniesienie do migracji Polaków do tego obszaru, aczkolwiek tamtejsze skupiska polskie i polonijne kształtowane były w innej rzeczywistości historycznej i współczesnej.

Region Arabii przez kolejne wieki stanowił swoisty temat tabu dla polskiego odbiorcy, ponieważ docierali tam jedynie niewolnicy, brani w jasyr przez zagony tatarskie i dalej sprzedawani do świata arabskiego oraz jeńcy, dostający się do niewoli tureckiej w trakcie zmagań wojennych prowadzonych przez dawną Rzeczpospolitą. Tak dalekie oddalenie ich od Stambułu decydowało w praktyce, że na ziemie polskie nie docierały praktycznie żadne informacje na ich temat, a jakiekolwiek próby wykupienia ich z niewoli także kończyły się niepowodzeniem. Inne formy kontaktów ograniczane były do bezwzględnego minimum. Sytuacja taka zmieniła się nieco po zażegnaniu zagrożenia ze strony Turcji, co nastąpiło po pokoju karłowickim z 1699 r. Poprawa relacji polsko-tureckich spowodowała, że do Stambułu, a za jego pośrednictwem także do innych ziem zdominowanych przez Turków, zaczęli docierać mieszkańcy ziem polskich w nowym charakterze. Agnieszka Bakalarz, analizująca kontakty Polaków z Arabią Saudyjską, podzieliła tych migrantów na cztery zasadnicze grupy: polskich Tatarów udających się na pielgrzymki

2 Wskazując na bardziej rozbudowane teorie wyróżnić można następujące typy takich migracji: dobrowolne, spontaniczne, planowe i przymusowe - w zależności od charakteru podejmowanych decyzji; zarobkowe, rodzinne, podporządkowane, matrymonialne, polityczne, religijne, narodowościowe, ekologiczne i indywidualne - w zależności od przyczyn migracji; stałe, okresowe i sezonowe - w zależności od czasu trwania migracji; wewnętrzne, zewnętrzne, kontynentalne, zamorskie i regionalne - w zależności od charakteru geograficznego migracji; z miast do miast, z miast do wsi, ze wsi do wsi i ze wsi do miast - w zależności od osadnictwa migracji; legalne i nielegalne - w zależności od charakteru prawnego migracji; emerytalne, masowe, konserwatywne, innowacyjne oraz mające charakter exodusu - w zależności od innych rodzajów migracji. Por. K. Slany, Między przymusem a wyborem. Kontynentalne i zamorskie emigracje z krajów Europy Środkowo-Wschodniej (1939-1989), Kraków 1995. 
do Mekki; „poturczeńców”; polskich muzułmanów biorących udział w pielgrzymkach do Mekki; polskich niemuzułmanów w Mekce i Medynie ${ }^{3}$. Szczególną grupę osób biorących udział w wyprawach do Arabii stanowili od XVIII w. polscy hodowcy koni. Wśród nich szczególną rolę odegrał Wacław Seweryn Rzewuski ${ }^{4}$, który nie tylko udał się na Półwysep Arabski po czworonożne zwierzęta juczne, ale mógł też przez kilkanaście lat pobytu pozostawać pod znamienitym wpływem świata arabskiego. Za jego pośrednictwem do mieszkańców ziem polskich dotarły wspomnienia, rysunki, opowieści i legendy z tego regionu ${ }^{5}$.

Region ten nie wywarł praktycznie żadnego znaczenia wśród polskich emigrantów zarobkowych z XIX i XX stulecia, poszukujących zatrudnienia w różnych częściach świata. Sytuacji tej nie zmieniły najważniejsze wydarzenia z dziejów narodu i państwa polskiego, jak XVIII-wieczne konfederacje czy powstania narodowe. Ziemie arabskie w tej części globu pozostające pod dużymi wpływami politycznymi Turcji uznawane były za niedostępne, niegościnne i niezbyt intratne pod względem wykorzystania gospodarczego. W niewielkim stopniu kontakty Polaków z Półwyspem Arabskim ożywiły się po odrodzenia państwa polskiego i próbach nawiązania bliższych relacji bezpośrednich ${ }^{6}$.

\section{A. Bakalarz, Polaków odkrywanie Arabii..., s. 33-96.}

4 Wacław Seweryn Rzewuski (1784-1831) - podróżnik, orientalista, pamiętnikarz, poeta i znawca koni. W 1817 r. wyjechał na Wschód w misji zakupu koni arabskich dla cara Aleksandra I. W latach 1818-1820 podróżował po Bliskim Wschodzie. W Arabii poznał pustynię i jej mieszkańców. Zwiedził Syrię, Irak, Liban oraz Palestynę. W 1818 r. jako jeden z wodzów eskorty dotarł wraz z wielką pielgrzymką do bram Mekki. Pozyskał zaufanie i przyjaźń przywódców plemion beduińskich. Z Beduinami mieszkał, polował, świętował i brał udział w ich wyprawach wojennych. Kunszt wojenny i odwaga przyniosły mu uznanie i sławę. Przyjęty do trzynastu plemion arabskich otrzymał tytuł emira i imiona: Tadż al-Fahr („Korona sławy”), Abd al-Niszan („Sługa znaku”). Zob. W. i Ta. Słabczyńscy, Słownik podróżników polskich, Warszawa 1992, s. 269-271.

5 Zob. A. Bakalarz, Polaków odkrywanie Arabii..., op.cit., s. 97-113.

6 Przed II wojną światową na Półwyspie mieszkał jedynie Fuad Ahmed 
Co prawda w okresie międzywojennym strona arabska była zainteresowana pozyskaniem polskiej broni i amunicji, ale problemy z płatnościami spowodowały, że tylko nieliczne transporty tego asortymentu dotarły na Półwysep Arabski. Tym samym nie doszło do wysłania do Arabii większej grupy specjalistów, którzy mieliby nadzorować rozwój przemysłu zbrojeniowego. Grupę polskich obserwatorów ziem arabskich stanowili jedynie dziennikarze ${ }^{7}$, pracownicy i urzędnicy ministerialni, Tatarzy polscy ${ }^{8}$ oraz duchowni ${ }^{9}$, a więc nie sensu stricto wychodźstwo zarobkowe $^{10}$. Także okres II wojny światowej nie przyniósł pod tym względem poważniejszych zmian. Mimo pojawienia się dużych grup polskich uchodźców wojennych na Bliskim i Środkowym Wschodzie oraz w Afryce Północno-Wschodniej i Wschodniej, region Półwyspu Arabskiego pozostawał dla nich nadal mało gościnny. Wynikało to z faktu peryferyjnego położenia tego obszaru wobec toczącego się konfliktu zbrojnego na skalę międzynarodową.

Sawicki, który 34 lata swego życia spędził w Egipcie. Prowadził on roboty w kamieniołomie pod Rijadem związane z budową odcinka drogi łączącej okręg stołeczny z Medyną. Por. O. Budrewicz, Bez radaru w świat, Warszawa 1960, s. 33.

7 Jednym z takich przykładów był przekaz pozostawiony przez Tadeusz Radkowskiego: Na pograniczu Arabji: opowiadanie z podróży, Wydawnictwo Domu Prasy Katolickiej, Warszawa 1929. Zob. też: A. Bakalarz, Ibn Saud w relacjach Polaków w latach 30. XX wieku, „Krakowskie Studia Międzynarodowe" 2009, nr 1, s. 213-221.

8 Zob. S. Korwin-Pawłowski, Wspomnienia. Wyścig z życiem, Warszawa 1966.

9 Przykładem takim była podróż podjęta na Półwysep Arabski przez Władysława Szczepańskiego: M. Wawrzynkiewicz, Władysław Szczepański (1877-1927): podróż polskiego jezuity do Arabii Skalistej, „Nowy Filomata” 2016, nr 1, s. 110-125.

10 Zob. A. Kapiszewski, Stosunki polsko-saudyjskie w okresie międzywojennym, „Przegląd Orientalistyczny” 2001, nr 1/2, s. 45-52; idem, Establishing Relations Between Poland and Saudi Arabia: Count Raczyński's visit to King Abdulaziz in 1930 and Prince Faisal's to Warsaw in 1932, „Państwo i Społeczeństwo" 2003, nr 1, s. 107-112. 
Od I wojny światowej coraz większą rolę polityczną w regionie tym zaczęli uzyskiwać Brytyjczycy, którym zależało na sprawnym użytkowaniu Kanału Sueskiego oraz zabezpieczeniu szlaków komunikacyjnych z Indiami. W związku z odkryciem tam dużych pokładów ropy naftowej, zaczęli pojawiać się w tej części świata przedstawiciele przedsiębiorstw i korporacji amerykańskich, mających już duże doświadczenie w eksploatacji tego ważnego surowca mineralnego. Wzrost znaczenia motoryzacji i transportu kołowego po II wojnie światowej tylko tendencje te ugruntował. Półwysep Arabski z regionu ubogiego i zacofanego gospodarczo stał się jednym z ważniejszych pod względem surowcowym. Poprzez wydobycie ropy naftowej i towarzyszącego jej gazu ziemnego do obszaru tego zaczął docierać międzynarodowy kapitał inwestycyjny, a wraz z nim przybywali specjaliści i kadry naukowo-techniczne, które sukcesywnie go rozwijały. Dzięki docierającym tam petrodolarom rynek arabski stał się wielkim placem budowy, który szybko doganiał pod względem technicznym i cywilizacyjnym inne najbardziej rozwinięte części świata. Ogłaszane przez organy państw arabskich przetargi bądź oferowane konkretne zlecenia decydowały o napływie dalszych kadr zatrudnianych na kontraktach indywidualnych i zbiorowych ze świata zachodniego ${ }^{11}$.

Po II wojnie światowej, kiedy w Warszawie zwyciężył ostatecznie reżim komunistyczny, silnie powiązany z instytucjami i organami Związku Radzieckiego, szukano różnorodnych porozumień ze światem arabskim. Mimo że kilka podmiotów z tego obszaru udało się zainteresować ideologią komunistyczną, to jednakże kwestie te nie dotyczyły praktycznie Półwyspu Arabskiego, który wierny pozostał swym konserwatywnym

11 Kwestie te omówił m.in. Paweł Raja: Specyfika gospodarczo-społeczna Pótwyspu Arabskiego: ujęcie historyczne, [w:] Problemy regionalizmu, red. J. Rymarczyk, M. Domiter, W. Michalczyk, Wrocław 2010, s. 294-302. 
i religijnym ideałom ${ }^{12}$. Pewną próbą zainteresowania Arabii Saudyjskiej budową kompletnych obiektów przemysłowych była aplikacja złożona w połowie lat 50. XX w. odnosząca się do odbudowy kolei transarabskiej, którą wybudowano jeszcze staraniem imperium tureckiego, a która została częściowo zniszczona w latach I wojny światowej. W tym celu wysłano do regionu delegację kilkudziesięciu inżynierów związanych z eksportowym przedsiębiorstwem Cekop, czyli Centralą Eksportu Kompletnych Obiektów Przemysłowych, której celem było przygotowanie przetargu na opracowanie projektu odbudowy Kolei Hidżaskiej oraz nadzór techniczny nad tymi pracami. Owocem tej wyprawy było przygotowanie projektu starającego się o wygranie przetargu na to przedsięwzięcie, w którym wystartowało ostatecznie 27 firm z całego świata. Przygotowana przez przedsiębiorstwo Cekop dokumentacja okazała się najlepsza, ale do ostatecznej realizacji przedsięwzięcia nie doszło na skutek działań podejmowanych przez korporacje amerykańskie, jak również rządy państw zachodnich, obawiających się rozpowszechnienia wpływów komunistycznych w tej części świata. Opowiedzenie się Arabii Saudyjskiej, jak też innych

12 Wyłom taki udało się jedynie dokonać na południu regionu w Jemenie, gdzie na skutek wojny domowej doszło do rozłamu i powołania do życia Jemenu Północnego i Południowego. Mimo powstania Jemeńskiej Republiki Ludowo-Demokratycznej nie dotarli tam jednak polscy specjaliści i kadry naukowo-techniczne. W konflikcie jemeńskim wzięli udział pojedynczy wojskowi wywodzący się z emigracji zachodniej, jak Rafał Gan-Ganowicz. Jako uczestnik powstania warszawskiego udał się na Zachód, gdzie został żołnierzem oddziałów wartowniczych przy armii amerykańskiej. W 1967 r. dotarł na Półwysep Arabski, gdzie został zaangażowany przez stronę saudyjską w konflikcie jemeńskim. Po obaleniu w tym kraju monarchii, władze republikańskie zostały wsparte przez oddziały egipskie, a przeciwko nim wystąpiła armia saudyjska. Na Półwyspie przebywał on do końca 1969 r., kiedy armia egipska zaczęła wycofywać się z tego obszaru. Zob. R. Gan-Ganowicz, Kondotierzy, Warszawa 1999, s. 167-169. Wojskowy ten we wspomnieniach zapisał, iż na Półwyspie walczyli jeszcze m.in. Mieczysław Czubak i Stefan Masternak. Zob. ibidem, s. 253-254. 
państw Półwyspu, za polityką Stanów Zjednoczonych, spowodowało ochłodzenie kontaktów między stronami, a wręcz ich zamrożenie. Polska nie mogła nawiązać oficjalnych stosunków dyplomatycznych z państwami regionu, a tym samym, do obszaru tego nie docierali migranci znad Wisły ${ }^{13}$.

Większe otwarcie Zjednoczonych Emiratów Arabskich na świat zachodni spowodowało pewne zainteresowanie tego podmiotu Europą Środkowo-Wschodnią, w tym Polską. W latach 80. XX w. w państwie tym zatrudnienie otrzymało ok. 50 lekarzy, którzy podjęli zatrudnienie w miejscowych szpitalach. $\mathrm{Z}$ ramienia Polimex-Cekopu oraz Instalexportu $\mathrm{w}$ regionie znaleźli się specjaliści na kontraktach inwestycyjnych ${ }^{14}$. Inne państwa regionu, nawet Ludowo-Demokratyczna Republika Jemenu, nie wykazywały większego zainteresowania polskimi kadrami naukowo-technicznymi. Jedynie na studia w Polsce przybywali Jemeńczycy z tego obszaru, dzięki czemu doszło do założenia pojedynczych rodzin mieszanych.

Większą grupą mieszkańców związanych z ziemiami polskimi, jacy zaczęli docierać na Półwysep Arabski stanowili przedstawiciele Polonii państw zachodnich. W związku z zapotrzebowaniem na kadry naukowo-techniczne związane z rozwojowym przemysłem wydobywczym, co miało związek z eksploatacją złóż naturalnych na terenie Półwyspu, władze poszczególnych państw nawiązywały kontrakty gospodarcze i umowy międzynarodowe z przedsiębiorstwami i koncernami, które mogłyby doprowadzić do sprawnego ich wykorzystania. Jako oddelegowani pracownicy takich korporacji, w charakterze inżynierów, urzędników czy

13 Mimo takiego stanu relacji polskie towary były obecne na rynku saudyjskim: Agros eksportował tam wyroby cukiernicze; Konfexim i Textilimpex konfekcję i tkaniny; Varimex - armaturę żelazną. Eksport towarów nie wiązał się jednak z wysyłaniem kadr naukowo-technicznych do tego kraju. Por. J. Piotrowski, Stosunki Polski z krajami arabskimi, Warszawa 1989, s. 49-50.

14 Ibidem, s. 49-50. 
menadżerów przybywali oni najczęściej na kontrakty zbiorowe ${ }^{15}$. Osobom takim towarzyszyły rodziny bądź przedstawiciele innych zawodów, jak architekci czy muzycy, którzy zawierali kontrakty indywidualne. Postacie takie świadczyły usługi najczęściej w logistyce restauracyjno-hotelarskiej bądź w różnych przedsięwzięciach rozrywkowych przygotowywanych dla specjalistów z Zachodu. Trudno jednoznacznie określić jak liczna była to grupa Polonii skupiona na tym obszarze w 2. połowie XX w., gdyż występowała ona jako obywatele innych państw, ale z pewnością nie były to osoby pojedyncze. Wyjazdy studyjne młodych Arabów na uniwersytety w Europie Zachodniej i Ameryce Północnej także prowadziły do zawierania związków małżeńskich z przedstawicielkami Polonii. Podróżowały one następnie w towarzystwie swoich mężów do nowych krajów osiedlenia.

Na przełomie lat 80. i 90. XX w. pojawiła się w rejonie Zatoki Perskiej najliczniejsza - jak dotąd - grupa Polaków, która wzięła udział w międzynarodowej operacji militarnej pod nazwą Pustynna Burza. Miała ona na celu odblokowanie Kuwejtu, zajętego uprzednio przez wojska irackie oraz przywrócenie pełnej podmiotowości międzynarodowej temu państwu. Polska odpowiedziała wówczas pozytywnie na apel dyplomacji amerykańskiej, który to podmiot rozpoczął wieloetapowe przygotowania operacyjne mające na celu odbudowę struktur państwowych emiratu. W związku z tym, iż jednym z najważniejszych uczestników tej akcji militarnej była Arabia Saudyjska, tak więc państwo to finansowało przedsięwzięcie i udostępniło bazy wojskowe na swoim terenie dla międzynarodowej ekspedycji. Ze

15 Do osób takich należał m.in. Adam Berestyński, który jako architekt w 1982 r. wyruszył do Arabii Saudyjskiej. Został on zaangażowany przez kalifornijską firmę inżynieryjną Saudi Arabian Parsons Ltd., która otrzymała zlecenie opracowania planu generalnego dla nowego miasta przemysłowego Janbu. Na skutek zawartego kontraktu spędził on na Półwyspie ponad siedem lat. Zob. A. Berestyński, Babie lato, Kraków 2000, s. 180. 
strony polskiej w konflikcie tym, w latach 1990-1991, uczestniczyło 393 wojskowych ${ }^{16}$. Przystąpienie Polski do koalicji państw o antyirackim charakterze, a także postępującą nad Wisłą transformacja systemu politycznego, która doprowadziła do reorientacji jej polityki zagranicznej, spowodowała korzystniejsze nastawienie państw Półwyspu Arabskiego do władz w Warszawie. Dzięki temu nawiązano pełnoprawne stosunki polityczne, którym towarzyszył rozwój kontaktów społecznych, gospodarczych i kulturalnych. Przykładem tym była Arabia Saudyjska, która do początku lat 90. XX w. konsekwentnie odmawiała ustanowienia polskich placówek dyplomatycznych na swoim terenie.

Występujące na przełomie XX i XXI w. skupiska polskie i polonijne na Półwyspie Arabskim liczyły od kilku do kilkuset przedstawicieli, w zależności od konkretnego podmiotu międzynarodowego. Było to związane ze stabilnością polityczną państwa, posiadaną przez niego pozycją ekonomiczną i finansową, otwartością na cywilizację Zachodu, przyjazdami licznych grup turystów, którymi należało się zaopiekować bądź możliwościami znalezienia zatrudnienia na miejscu ${ }^{17}$.

Skupisko w Arabii Saudyjskiej składało się - wraz z polsko-arabskimi rodzinami mieszanymi - z ok. 200 osób. W grupie tej wyróżniali się lekarze, fizjoterapeuci, pielęgniarki, inżynierowie (architekci i urbaniści, informatycy, automatycy, łącznościowcy, osoby zatrudnione w przemyśle naftowym) oraz biz-

16 W. Góralski, Udziat Polski w misjach pokojowych w krajach Azji i Afryki (1953-1993), „Przegląd Orientalistyczny” 1996, nr 3-4, s. 119-132; K. Łastawski, Misje i operacje pokojowe w polskiej polityce zagranicznej, „Stosunki Międzynarodowe” 2006, nr 1-2, s. 29-40; J. Zając, Udziat Polski $w$ misjach pokojowych i stabilizacyjnych na poczatku XXI wieku, „Krakowskie Studia Międzynarodowe” 2007, nr 4, s. 191-207; http://skmponz.pl/ misje-pokojowe-polakow-1953-2010 [dostęp: 10.12.2016].

17 Skupiska polskie i polonijne na Półwyspie Arabskim, wykorzystując materiały zdeponowane w Departamencie Polonii MSZ, zreferował Jacek Knopek. Zob. idem, Przemiany zbiorowości polonijnych w Azji, „Dzieje Najnowsze" 2000, nr 1, s. 216-218. 
nesmeni. Część z nich przyjechała z Polski, jednakże większość wywodziła się z Polonii z innych krajów (Australii, Jordanii, Kanady, Libanu, Niemiec, Szwajcarii, USA, Wielkiej Brytanii). Do pierwszej grupy zalicza się głównie Polki, które wyszły za mąż za Saudyjczyków. Do grupy drugiej osoby, które przybyły na kontrakty jako obywatele państw trzecich nieposiadające często już obywatelstwa polskiego ${ }^{18}$.

W Bahrajnie zbiorowość ta liczyła 100-120 osób. W większości byli to obywatele polscy zatrudnieni na kontraktach zbiorowych i indywidualnych. Poza specjalistami, pracującymi w stoczni remontowej w Manamie, zatrudnienie tam znaleźli członkowie zespołów muzycznych, tanecznych i innych grup rozrywkowych. Kilkunastoosobową grupę stanowiły także Polki, które wyszły za mąż za obywateli tego kraju i zdecydowały się na wyjazd do Zatoki Perskiej.

Najliczniejszą grupę polską i polonijną odnotować można było w Zjednoczonych Emiratach Arabskich, która należała jednocześnie do najlepiej zorganizowanych w świecie arabskim. Jej wielkość szacowano na ok. 600 osób, w większości zamieszkujących emiraty Dubaju i Szardży oraz wielkiego emiratu Abu Zabi. Aktywność zawodowa Polonii wyrosła na tle kontraktów indywidualnych i zbiorowych, następnie przedłużanych przez samych polskich specjalistów na własną rękę. Fakt ten zdecydował, iż znaczącą część tej społeczności stanowili inżynierowie, pracownicy wykwalifikowani oraz kadra medyczna. Zatrudnienie w tym kraju uzyskali także sportowcy, trenerzy, muzycy i zespoły artystyczne. W kraju tym skupiało się też kilkanaście małżeństw mieszanych. Społeczność ta, jako jedyna w regionie, doprowadziła do wydawania czasopisma polonijnego pt. „Piasek”.

18 A. Bakalarz, Polaków odkrywanie Arabii Saudyjskiej..., op.cit., s. 196$-197$. 
W pozostałych państwach regionu przebywały jedynie zbiorowości kilku-, kilkunasto- bądź kilkudziesięcioosobowe ${ }^{19}$. Spośród nich najliczniejsza, bo 30-osobowa grupa, znalazła miejsce zamieszkania w Katarze. Swą specyfiką przypominała ona społeczność polonijną z Bahrajnu.

Wielowiekowe kontakty łączące Polskę i Polaków ze światem i państwami arabskimi przyniosły różnorodne formy relacji, od migracji żywiołowych (niewolnicy, jeńcy) poprzez poznawcze (podróżnicy, pielgrzymi, publicyści), naukowe (studenci, nauczyciele akademiccy) i matrymonialne (związki małżeńskie) do migracji zorganizowanych (specjaliści, wojskowi). Niemniej relacje z Półwyspem Arabskim należały do peryferyjnych, najmniej licznych i słabo zorganizowanych. Dopiero dynamiczny rozwój gospodarczy tego regionu, prowadzony od lat 70. XX w. zmienił te tendencje i doprowadził do powstania skupisk polskich i polonijnych w tej części świata. Społeczności te nie były i nadal nie są zbyt liczne, charakteryzują się dużą zmiennością miejsca pobytu, spotykają się i integrują w miarę możliwości, a ogniwem spajającym je są od 1989 r. polskie placówki dyplomatyczne. Większą stałością charakteryzują się polsko-arabskie rodziny mieszane, które o ile wytrwały w swych postanowieniach, mieszkają na miejscu, ale swoje potomstwo najczęściej kierują na studia do państw zachodnich bądź do Polski. Tendencje te powodują, że zbiorowości polskie i polonijne nadal będą podlegać dużym zmianom, a ich obecność bądź potencjalny rozwój zależne będą od dalszej dynamiki gospodarczej tego regionu świata.

19 Zob. A. Taffal, Poland and Palestine - Contemporary Relations, „Środkowoeuropejskie Studia Polityczne” 2015, nr 4, s. 185-196. 


\section{Bibliografia}

\section{Literatura}

Bakalarz A., Ibn Saud w relacjach Polaków w latach 30. XX wieku, „Krakowskie Studia Międzynarodowe” 2009, nr 1.

Bakalarz A., Polaków odkrywanie Arabii Saudyjskiej, Kraków 2005.

Berestyński A., Babie lato, Kraków 2000.

Budrewicz O., Bez radaru w świat, Warszawa 1960.

Bystroń J.S., Polacy w Ziemi Świętej, Syrji i Egipcie 1147-1914, Kraków 1929.

Gan-Ganowicz R., Kondotierzy, Warszawa 1999.

Góralski W., Udziat Polski w misjach pokojowych w krajach Azji i Afryki (1953-1993), „Przegląd Orientalistyczny” 1996, nr 3-4. Kaczmarek H., Polacy w Egipcie do 1914 roku, Szczecin 2008. Kapiszewski A., Establishing Relations Between Poland and Saudi Arabia: Count Raczyński's visit to King Abdulaziz in 1930 and Prince Faisal's to Warsaw in 1932, „Państwo i Społeczeństwo" 2003, nr 1.

Kapiszewski A., Stosunki polsko-saudyjskie w okresie międzywojennym, „Przegląd Orientalistyczny” 2001, nr 1/2.

Knopek J., Migracje Polaków do Afryki Pótnocnej w XX wieku, Bydgoszcz 2001.

Knopek J., Przemiany zbiorowości polonijnych w Azji, „Dzieje Najnowsze" 2000, nr 1.

Korwin (Pawłowski) S.A., Stosunki Polski z Ziemiq Święta, przedm. J. Mitkowski, Warszawa 1958.0

Korwin-Pawłowski S., Wspomnienia. Wyścig z życiem, Warszawa 1966.

Kościałkowski S., Polacy a Liban i Syria w toku dziejowym, Bejrut 1949.

Łastawski K., Misje i operacje pokojowe w polskiej polityce zagranicznej, „Stosunki Międzynarodowe” 2006, nr 1-2. 
Piotrowski J., Stosunki Polski z krajami arabskimi, Warszawa 1989.

Radkowski T., Na pograniczu Arabji: opowiadanie z podróży, Warszawa 1929.

Raja P., Specyfika gospodarczo-społeczna Pótwyspu Arabskiego: ujęcie historyczne, [w:] Problemy regionalizmu, red. J. Rymarczyk, M. Domiter, W. Michalczyk, Wrocław 2010.

Slany K., Między przymusem a wyborem. Kontynentalne i zamorskie emigracje z krajów Europy Środkowo-Wschodniej (1939-1989), Kraków 1995.

Słabczyńscy W. i T., Słownik podróżników polskich, Warszawa 1992.

Taffal A., Poland and Palestine - Contemporary Relations, „Środkowoeuropejskie Studia Polityczne” 2015, nr 4.

Wawrzynkiewicz M, Władysław Szczepański (1877-1927): podróż polskiego jezuity do Arabii Skalistej, „Nowy Filomata” 2016, nr 1.

Zając J., Udziat Polski w misjach pokojowych i stabilizacyjnych na poczatku XXI wieku, „Krakowskie Studia Międzynarodowe" 2007, nr 4.

\section{Netografia}

http://skmponz.pl/misje-pokojowe-polakow-1953-2010.

\section{Abstrakt}

W artykule wskazuje się na pobyt i działalność Polaków w państwach położonych na terenie Półwyspu Arabskiego, do których zaliczono Arabię Saudyjską, Bahrajn, Jemen (po II wojnie światowej występował tam Jemen Południowy i Jemen Północny), Katar, Oman oraz Zjednoczone Emiraty Arabskie.

Kontakty Polaków z tym regionem świata w przeszłości były niewielkie. Na Półwysep Arabski trafiali zatem nieliczni mieszkańcy z ziem polskich. Sytuacja ta zmieniła się od lat 70 . XX w., kiedy państwa arabskie zaczęły dynamicznie się rozwijać w oparciu o uzyskiwane środki 
finansowe ze sprzedaży surowców naturalnych - ropy naftowej i gazu ziemnego. Dzięki temu przybywały tam kadry naukowo-techniczne oraz specjaliści z różnych dziedzin, ponadto przedstawiciele branży turystycznej oraz muzycy. Poprzez polsko-arabskie małżeństwa nad Zatoką Perską zamieszkały także Polki, które wyszły za mąż za Arabów. Występujące na przełomie XX i XXI w. skupiska polskie i polonijne na Półwyspie Arabskim liczyły od kilku do kilkuset przedstawicieli, w zależności od konkretnego podmiotu międzynarodowego. Pojedyncze osoby mieszkały w Jemenie i Omanie, 30 osób w Katarze, od 100 do 200 w Bahrajnie i Arabii Saudyjskiej, a 600 w Zjednoczonych Emiratach Arabskich. To ostatnie skupisko polonijne należało do najlepiej zorganizowanych w świecie arabskim.

Słowa kluczowe: Polska, Polacy, kraje arabskie, emigracja, cywilizacja

\begin{abstract}
The article discusses the stay and activity of the Poles in countries located in the Arabian Peninsula. Those countries include Saudi Arabia, Bahrain, Yemen (after the Second World War it was Southern Yemen and Northern Yemen), Qatar, Oman and the United Arab Emirates.

Polish contacts with this region of the world were occasional in the past. Therefore, only few inhabitants of Poland came to the Arabian Peninsula. This situation has changed since the 1970s, when Arab countries began to develop dynamically on the base of obtained financial resources from the sale of natural resources - crude oil and natural gas. Thanks to it, scientific and technical staff and specialists from various fields arrived, as well as representatives of the tourism industry and musicians. Polish-Arab married couples also settled in the Arabian Gulf as a result of Polish women marrying Arab men.

At the turn of the $21^{\text {st }}$ century, the size of Polish community and Polish diaspora in the Arabian Peninsula stretched from several individuals to several hundred representatives, depending on the country they were based in. Some individuals lived in Yemen and Oman, 30 people in Qatar, 100 to 200 in Bahrain and Saudi Arabia. And 600 Poles lived in the United Arab Emirates, which was one of the best organized communities in the Arab world.
\end{abstract}

Keywords: Poland, Poles, Arab countries, emigration, civilization 


\section{Katarzyna Ciepiela}

Krakowska Akademia im. Andrzeja Frycza Modrzewskiego

ORCID ID: https://orcid.org/0000-0001-6145-8451

\section{Wybory prezydenckie w Indonezji - Jokowi czy Prabowo?}

\section{Wstęp}

17 kwietnia 2019 r. odbyły się największe na świecie wybory prezydenckie. Blisko 192 mln uprawnionych do głosowania mieszkańców mogło podjąć decyzję, czy Joko „Jokowi” Widodo albo Prabowo Subianto zasiądą na fotelu prezydenckim. W tym roku połączone zostały wybory prezydenckie, parlamentarne i lokalne, w których startuje 245 tys. kandydatów, a ok. 6 mln osób zasiada w lokalnych komisjach wyborczych ${ }^{1}$. Wybory są powtórką z 2014 r. kiedy to ci sami kandydaci starli się w wyborach prezydenckich. Tegoroczne wybory skupiły się na kilku tematach: stanie gospodarki, rozwoju infrastruktury pod rządami Jokowi, roli islamu w polityce oraz perspektywy dla millenialsów, którzy stoją przed wyzwaniem szybko zmieniających się warunków ekonomicznych i technologicznych. Kończąca się 5-letnia kadencja Jokowi umocniła jego pozycję na arenie politycznej w kraju i na świecie. Droga jaką przebył od bycia burmistrzem Solo, następnie gubernatorem Dżakarty i prezydentem Indonezji pokazuje, że zmiany jakie zacho-

1 J. Blank, What Jokowi's Reelection Means for Indonesia a Vote to Preserve Hard-Earned Progress, https://www.foreignaffairs.com/articles/indonesia/2019-04-22/what-jokowis-reelection-means-indonesia , [dostęp: 5.05.2019]. 
dzą w kraju są coraz bardziej widoczne, gdzie elity polityczne i militarne przechodzą wewnętrzną reorganizację. Prabowo Subianto, który nie ukrywa swoich wielkich aspiracji prezydenckich próbuje za wszelką cenę wygrać wybory mobilizując radykałów religijnych. Prowadzona kampania wyborcza nie przyniosła żadnych wielkich deklaracji co do rozwoju kraju, jak i prezentowane przez kontrkandydatów pomysły były w większości zbieżne ze sobą. Wybór kandydatów na wiceprezydentów był również zachowawczy, aby nie stracić poparcia żadnej grupy wyborczej. Obóz Joko Widodo został wsparty przez Ma'ruf Amina - duchownego, polityka, nauczyciela, a przede wszystkim przewodniczącego Nahdlatul Ulama - największej islamskiej organizacji. Natomiast Prabowo Subianto wybrał Sandiaga Uno - młodego prężnie działającego biznesmena wicegubernatora Dżakarty.

\section{Kampania wyborcza}

Kampania wyborcza prowadzona była już od 2018 r., starając się przygotować odpowiednie założenia i szukać sojuszników $\mathrm{w}$ walce o fotel prezydencki.

Kampanię wyborczą prowadzoną przez Jokowi i Prabowo można podzielić na trzy części². Pierwsza to prowadzenie debaty politycznej w telewizji i związany z tym dyskurs. Jokowi prezentował optymistyczną wizję swojej prezydentury - ekonomicznego rozwoju kraju, kontroli złóż srebra, złota i miedzi w Górach Śnieżnych w prowincji Papua oraz złożach naftowych w Mahakan i Rokan (to odpowiedź na zarzuty Prabowo, określającej Jokowi jako „lokaja zagranicznych korporacji”, pozwalającego na nieograniczone korzystanie z naturalnych za-

2 M. Lane, The 2019 Indonesian Election: An Overview, „Perspective ISEAS Yusof Ishak Institute” 2019, nr 49, s. 2. 
sobów kraju). Najbardziej widocznym punktem kampanii było skupienie się na infrastrukturze i bezpieczeństwie socjalnym. Rozwój infrastruktury obrazował ilością zbudowanych dróg, mostów, linii kolejowej oraz lotnisk na terenie całego kraju. Otwarcie zgodnie z planem długo wyczekiwanego pierwszego w Indonezji systemu Zorganizowanego Szybkiego Transportu ( MRT - Mass Rapid System) namacalnie miało pokazać w jakim kierunku zmierza rozwój kraju. Deklarował również przeniesienie stolicy kraju z Dżakarty na wyspę Borneo, aby ułatwić funkcjonowanie mieszkańców tej wielkiej aglomeracji. Podczas pierwszej debaty pojawiły się postulaty wspierania „indonezyjskich jednorożców” określanych tak technologicznych start-upów, które szturmem pojawiły się na rynku i są wizytówką kraju. Odnosił się tu głównie do firmy Go-Jek, która zyskała światową sławę i idealnie wpasowała się potrzeby mieszkańców archipelagu ${ }^{3}$. Zabezpieczenie socjalne również znalazło ważne miejsce w kampanii. Po wprowadzeniu bezpłatnego ubezpieczenia zdrowotnego dla mieszkańców kraju, pojawiła się propozycja zabezpieczenia socjalnego dla bezrobotnych. Populizm prezentowany w kampanii wyborczej można określić jako pragmatyczny i umiarkowany.

Prabowo natomiast propagował pesymistyczną wizję rozwoju kraju pod rządami Jokowi - co sztab obecnego prezydenta nie omieszkał użyć w swojej kampanii, pokazując, że należy być optymistą nie pesymistą w stosunku do narracji sztabu Prabowo mówiącej o potrzebie drastycznych zmian - bo inaczej nastąpi upadek kraju. Poprzez populistyczne i nacjonalistyczne tezy wskazywał na powiększającą się różnicę między bogatymi a biednymi, rozległą biedę jaka ogarnia kraj, bardzo słaby wzrost PKB w stosunku do innych państw azjatyckich oraz odpływ bogactwa z Indonezji. Sandiaga Uno, kandydat

3 B. Bland, Indonesia's election debates: there's substance in the style, „The Interpreter” 2019 
na wiceprezydenta, prezentował zrównoważony plan rozwoju ekonomicznego kraju 4 . Podkreślał potrzebę tworzenia nowych miejsc pracy i stabilizacji rosnących cen artykułów domowych $^{5}$. Kampania skierowana była do przedstawicieli obu płci, ponieważ ok. $96 \mathrm{mln}$ kobiet i ok. $96 \mathrm{mln}$ mężczyzn posiada uprawnienia do głosowania. Odnosił się również pozytywnie do bezpośrednich inwestycji z Chin, co w kraju gdzie prześladowano chińską mniejszość oraz po wydarzeniach związanych z procesem wiceburmistrza Dżakarty- Basuki Tjahaja Purnama jest pewnym novum.

Druga część to skupienie się na aktywności w mediach, głównie mediach społecznościowych, na gruncie politycznym z jakiego dwóch kandydatów pochodzi. W dużej mierze skupiono się na identyfikacji religijnej w docelowych grupach społecznych - głównie wierzących muzułmanów. Możemy tutaj zobaczyć sporo znaczących sprzeczności. Jokowi jako kandydat nominowany przez partię PDIP - określanej jako najbardziej świeckiej partii politycznej w Indonezji - „nacjonalistycznej” w kontrze do „islamistycznej” czy religijnej jako swojego kandydata na wiceprezydenta wybrała Ma'ruf Amina - konserwatywnego duchownego, lidera Nahdatul Ulama. Wybór ten można uznać jako poszukiwanie patrona, dzięki któremu dotrze się do konserwatywnych wyborców. Był to bardzo słaby punkt zaplecza prezydenta. Wiedział też jaką siłą dysponują bardzo konserwatywne muzułmańskie organizacje, które pokazały swoją siłę podczas zamieszek związanych z procesem Basuki Tjahaja Purnama i utworzeniem Ruchu

4 M. Busch, Old habits die hard in Indonesia's presidential clash, https://indonesiaatmelbourne.unimelb.edu.au/old-habits-die-hard-in-indonesias-presidential-clash/ [dostęp: 22.11.2019].

5 Q. Temby, A. Najib Burhami, B. Irawanto, Indonesia's 2019 Elections: The Key Issues, „Perspective ISEAS Yusof Ishak Institute” 2019, nr 30, s. 2. 
$212^{6}$. Zdystansowane, a wręcz obojętne stanowisko podczas całego procesu byłego wiceburmistrza Dżakarty nie zamknęło mu drogi do odniesienia się do skrajnego elektoratu. Jokowi, tak jak we wcześniejszej kampanii prezydenckiej, występował w ogólnodostępnym strojach i wypowiadał się w zrozumiałym dla każdego stylu. W przeciwieństwie do Prabowo, który zawsze ubrany był w oficjalny strój i tradycyjną czapeczkę peci . Stworzony obraz przedstawiciela klasy średniej był antytezą dla typowego polityka posiadającego poparcie elit politycznych. Miało to pokazać również, że pięć lat prezydentury nie zmieniło nic w jego zachowaniu.

Prabowo podczas kampanii wyborczej starał zachować cały czas neutralność i otwartość na wszystkie religie. Bardzo rzadko odnosił się w swoich przemówieniach do tematów religijnych, co ciekawe rozpoczynał je pozdrowieniami dla wszystkich religii, w tym judaizmu - to samo dotyczy się Sandiaga Uno. Jednak mimo zachowania neutralności w przemówieniach w kampanii wyborczej widoczny był wyraźny sojusz z najbardziej walczącą, politycznie i społecznie islamską organizacją Ruch 212. Prabowo od początku powstania tego ruchu w 2016 r. wspierał go, licząc na wsparcie w przyszłości. Co ciekawe, jednym z głównych liderów tworzącego się ruchu był Ma'ruf Amin, który odciął się od tej organizacji, decydując się na start w wyborach prezydenckich.

Wsparcie jakie uzyskał Prabowo od najbardziej bojowych odłamów islamu przełożyło się na czarną kampanię w mediach społecznościowych skierowaną przeciw Jokowi. Nie zapo-

6 Sheany, Understaning 212 Movement, https://jakartaglobe.id/context/ understanding-212-movement [dostęp: 12.12.2019].

7 E. Renaldi, T. Shelton, Unicorns become an unexpected symbol of Indonesia's second presidential debate, ABC News, https://www.abc.net.au/ news/2019-02-18/joko-widodo-indonesia-presidential-debate-prabowosubianto/10820310 [dostęp: 10.11.2019]. 
mniano o zarzutach, że nie jest prawdziwym muzułmaninem i tak jak Basuki Tjahaja Purnama zasługuje na potępienie i nie powinien sprawować żadnych ważnych urzędów, ponieważ mogą to robić tylko oddani muzułmanie. Spowodowało to wiele zamieszek na terenie całego kraju. Poprzez nieskończoną ilość komunikatorów oraz łatwy dostęp do Internetu codziennie nowa porcja nieprawdziwych wiadomości docierała do szerokiego grona odbiorców ${ }^{8}$.

Trzecia część to możliwość utworzenia koalicji wyborczej. Jokowi w swojej koalicji zebrał dziesięć partii, natomiast Prabowo sześć partii, z czego dwie są kierowane przez członków rodziny Suharto.

Założeniem Jokowi było utworzenie koalicji, która będzie stanowiła całość. Szefem kampanii został Erick Thohir - biznesmen działający w branży mediów i szeroko pojętej branży rozrywkowej oraz inwestor wielu klubach sportowych, w tym Inter Milan. Aktywną rolę brały też udział Sri Mulyani i Puan Maharani - panie minister w rządzie Jokowiego oraz trzech gubernatorów: Ridwan Kamil - gubernator Jawy Zachodniej, Muhammad Zainul Majdi - gubernator Małych Wysp Sundajskich Zachodnich oraz Lukas Enembe - gubernator prowincji Papua. Należy zaznaczyć, że reprezentują oni Partię Demokratyczną, która popiera kandydaturę Prabowo. Walkę o fotel prezydenta rozpoczęto z ok. 800 tys. dolarów, a zakończono z 3,8 mln dolarów. Tak jak w wyborach z 2014 r. zwrócono się z prośbą do wyborców o wsparcie kampanii wyborczej ${ }^{9}$. Wybór Ma’rufa Amina na wiceprezydenta był taktycznym ruchem dla

8 K. Kapoor, Indonesian former general fires up masses in second run at presidency, Reuters, https://www.reuters.com/article/us-indonesia-election-prabowosubianto-pr/indonesian-former-general-fires-up-masses-insecond-run-at-presidency-idUSKCN1RQ03O [dostęp: 23.11.2019].

9 M. Mietzner, How Jokowi won and democracy survived, „Journal of Democracy" 2014, vol. 25, nr 4. 
obozu Jokowi. Indonezyjska scena polityczna chcąc osiągnąć zamierzone cele, zawsze skręcała ku religijnemu zapleczu, tam czekał twardy elektorat, który mógł zapewnić zwycięstwo ${ }^{10}$.

Prabowo tworząc swoją koalicję skupił się na utworzeniu bloku skupiającego się wokół jego osoby. Radykalne grupy proponowały na wiceprezydenta Ma'rufa Amina - Prabowo jednak nie zdecydował się na wybór tak silnej postaci. Pojawiła się również kandydatura syna byłego prezydenta Susilo Bambang Yudhoyono - AH Yudhoyono. Twórca Parti Demokratycznej liczył, że będzie to podziękowanie za wsparcie Prabowo w kampanii wyborczej. Tak się nie stało, co spotkało się z dużą niechęcią w samej partii. AH Yudhoyono ma wielkie plany na zostanie prezydentem Indonezji i prawdopodobnie to spowodowało niechęć Prabowo. Wybrany został Sandiaga Uno, który był kandydatem Gerindry w wyborach na gubernatora Dżakarty. Młody biznesmen, bez silnego zaplecza politycznego okazał się wg Prabowo idealnym kandydatem. Do tego był w stanie swoim majątkiem wspomóc kampanię wyborczą (znajduje się na 47. miejscu najbogatszych ludzi w Indonezji ${ }^{11}$. Wśród wyborców niezdecydowaną, a bardzo silną grupą wyborczą są młode osoby, w 2019 r. przybyło takich wyborców blisko $10 \mathrm{mln}$. Sandiaga Uno miał również przemówić do tej grupy jako przykład godny do naśladowania i mówiący językiem młodych ludzi ${ }^{12}$.

Szefem kampanii wyborczej został były generał Djoko Santoso, twarzą kampanii został były prezydent Susilo Bambang Yudhoyono, Rachmawati Sukarnoputri - córka Sukarno i sio-

10 E. Arifin, Will hard-line Islamist influence Indonesia's election?, The Asean Post, https://theaseanpost.com/article/will-hard-line-islamism-influence-indonesias-elections [dostęp: 23.11.2019].

11 S. Khidhir, Sandiaga Uno: From loser to winner...., op.cit.

12 B. Kinadi, A look ahead: 2019 Indonesia presidential election, Global Counsel, https://www.global-counsel.com/insights/blog/look-ahead2019-indonesia-presidential-elections [dostęp: 13.11.2019]. 
stra byłej prezydent Indonezji Megawati Sukarnoputri oraz Ahmad Muzani - polityk GERINDRA.

Komitet wyborczy wykazał, że zebrano ok. 3 mln dolarów - głównie wkładu dokonali Prabowo i Sandiga.

Tabela 1. Partie wspierające Joko Widodo w latach 2019 i w 2014

\begin{tabular}{|l|l|}
\hline 2019 & 2014 \\
\hline PDI-P & PDI-P \\
\hline GOLKAR & PKB \\
\hline PKB & Nasdem \\
\hline Nasdem & Hanura \\
\hline PPP & PKPI \\
\hline Perindo & \\
\hline PSI & \\
\hline Hanura & \\
\hline PBB & \\
\hline PKPI & \\
\hline
\end{tabular}

Źródło: https://pemilu2019.kpu.go.id/\#/ppwp/hitung-suara/ [dostęp: 12.12.2019].

Tabela 2. Partie wspierające Prabowo Subianto w latach 2019 i 2014

\begin{tabular}{|l|l|}
\hline 2019 & 2014 \\
\hline GERINDRA & GERINDRA \\
\hline PKS & GOLKAR \\
\hline DEMOKRAT & PKS \\
\hline PAN & DEMOKRAT \\
\hline Berkarya & PBB \\
\hline Garuda & PPP \\
\hline & PAN \\
\hline
\end{tabular}

Źródło: https://pemilu2019.kpu.go.id/\#/ppwp/hitung-suara/ [dostęp: 12.12.2019].

\section{Wyniki wyborów}

21 maja 2019 r. Indonezyjska Komisja Wyborcza (KPU - Komisi Pemilihan Umum) ogłosiła wyniki wyborów. 
Tabela 3. Wyniki wyborów prezydenckich w 2019 r. oraz w 2014 r. podane $w$ milionach:

\begin{tabular}{|l|c|c|c|}
\hline & 2019 & 2014 & Wzrost/Spadek \\
\hline Liczba ważnych głosów & $154,257,601$ & $133,574,277$ & $+20,683,324$ \\
\hline Joko Widodo/Ma'ruf Amin & $85,607,362$ & $70,997,850$ & $+14,609,512$ \\
\hline Prabowo Subianto/Sandiago Uno & $68,650,239$ & $62,576,444$ & $+6,073,795$ \\
\hline
\end{tabular}

Źródło: https://pemilu2019.kpu.go.id/\#/ppwp/hitung-suara/ [dostęp: 12.12.2019].

Joko Widowo podczas kampanii wyborczej w 2019 r. miał poparcie dziesięciu partii politycznych. Jest to więcej o dwie znaczące partie niż w 2014 r. Partie GOLKAR oraz PPP przeszły z obozu Prabowo Subianto. W 2014 r. nie istniała jeszcze partia PSI, która dołączyła do koalicji w 2019 r. Na prawie 155 mln ważnych głosów udało mu się uzyskać prawie $85 \mathrm{mln}$ głosów, co w porównaniu do 2014 r. jest 11\% skokiem. Uzyskał poparcie w 21 z 34 prowincji jakie znajdują się w Indonezji ${ }^{13}$.

Jokowi mógł liczyć na duże wsparcie w bardzo zaludnionej prowincji Jawa Centralna - 77,2\% głosów, prowincja Jawa Zachodnia - 67\% głosów, Bali - 91\% głosów, Małe Wyspy Sundajskie Zachodnie - 88,5\% i w prowincji Papua - 90\% głosów.

Prabowo uzyskał prawie 67 mln głosów, wygrał w trzynastu prowincjach, gdzie najwyższe wyniki w prowincji Zachodnia Sumatra $-85,9 \%$, porównywalnie w prowincji Aceh i w prowincjach znajdujących się poza Jawą ${ }^{14}$.

Wyniki te pokazują geograficzną polaryzację jaka ma miejsce w Indonezji. Porównywalne jest to do sytuacji z lat 50. XX w., gdzie pojawił się podział na mieszkańców etnicznej Jawy i reszty wysp nazwanych „the Outer Island”. Jest to m.in. związane $\mathrm{z}$ brakiem akceptacji do postulatów, jakie głoszą radykalne partie

13 J. Senkyr, President Jokowi wins the elections in Indonesia, Konrad Adenauer Stiftung, 2019, https://www.ecoi.net/en/file/local/2014145/190613Indonesia-Country+report-.pdf [dostęp: 2.02.2020] .

14 Idem, The 2019 Indonesian Election: An Overview..., op.cit. 
islamskie przez mniej radykalnymi indonezyjskimi muzułmanami czy etnicznymi Balijczykami i Chrześcijanami.

Wyniki w Specjalnym Dystrykcie Dżakarta pokazały równą walkę między kandydatami. Joko Widodo uzyskał 51,68\% głosów, a Prabowo Subianto 48,32\%. Pokazało to spadek poparcia dla koalicji GERINDRA-PKS, która wygrała wybory na fotel gubernatora w 2018 r. zdobywając 58\%.

Po ogłoszeniu wyników 21 maja 2019 r. doszło do zamieszek w Dżakarcie i innych miastach archipelagu. Zamieszki trwały od 21-23 maja, wzniecone przez zwolenników Prabowo Subianto-Sandiga Uno, którzy uznali wyniki za sfałszowane przez prezydenta Jokowi. W zamieszkach osiem osób zostało zabitych podczas starcia z policją, a kolejnych dziewięć zmarło w szpitalach, a setki zostało rannych. Poszukując winnych tej sytuacji okazało się, że główni prowoderzy zamieszek kierowani byli przez rozprzestrzenianie się fałszywych informacji poprzez media społecznościowe ${ }^{15} .22$ maja, aby ograniczyć rozprzestrzenianie się tych informacji minister komunikacji i informacji zablokował możliwość przesyłania i ściągania filmów wideo i fotografii na wielu platformach mediów społecznościowych m.in. WhatsApp, Facebook, Instagram i Twitter ${ }^{16}$. Prabowo Subianto złożył wniosek do Trybunału Konstytucyjnego w związku z niezgodnościami podczas przeprowadzenia wyborów, który został odrzucony 27 czerwca $^{17}$.

15 Q. Temby, Disinformation, Violece and Anti-Chinese Sentiment in Indonesia's 2019 Elections, „Perspective - ISEAS Yusof Ishak Institute” 2.09.2019, nr 67, s. 3.

16 M. Singh, J. Russell, Indonesia restricts WhatssApp, Facebook, Instagram usage following deadly riots, https://techcrunch.com/2019/05/22/ indonesia-restricts-whatsapp-and-instagram/ [dostęp: 26.12.2019].

17 D. Tomsa, Indonesia's polling industry after the 2019 elections, https://indonesiaatmelbourne.unimelb.edu.au/indonesias-polling-industry-after-the-2019-elections/ [dostęp: 1.12.2019]. 


\section{Podsumowanie}

Zorganizowanie tak wielkich wyborów w trzeciej co do wielkości demokracji świata oraz największym państwie muzułmańskim zasługuje na wielki szacunek całej społeczności międzynarodowej. Wyniki pokazały jak blisko siebie są kandydaci biorący udział w wyborach prezydenckich i w jakim kierunku może zmierzać przyszłość kraju. Prezydent Jokowi podtrzymał plany kontynuacji swojej polityki realizowanej podczas pierwszej kadencji. Główne wyzwania jakie stoją obecnie przed rządzącymi jest utrzymanie zrównoważonego rozwoju gospodarczego we wszystkich prowincjach oraz kontrola wpływu religii na podejmowane decyzje. Społeczeństwo oczekuje walki z korupcją, która jest obecna na wszelkich szczeblach władzy. Wielkim zagrożeniem jest brak świadomości politycznej wielu mieszkańców, co ujawniło się podczas zamieszek w trakcie kampanii wyborczej i po ogłoszeniu wyników wyborów. Ogólnokrajowe media podjęły próbę wyjaśniania społeczeństwu meandrów polityki, jak i prostowania nieprawdziwych wiadomości, jakie pojawiły się, przestrzeni publicznej - można tu przede wszystkim zwrócić uwagę na magazyn „Koran Tempo" czy portal coconuts.co. Jokowi zdaje sobie sprawę, że nowoczesne państwo musi mieć dostęp do nowych technologii, co bezpośrednio przekłada się na edukację społeczeństwa; stąd wyczekiwana jest reforma systemu edukacji. Konstytucja Indonezji jasno mówi, że jest to ostatnia kadencja obecnego prezydenta. To w jaki sposób będzie sprawował władzę i na ile pozwoli na ingerencję radykalnych przedstawicieli religijnych ukształtuje nową scenę wyborczą. Kampania wyborcza, która wg wielu opinii była spokojna, jednostajna i niczym nie zaskoczyła zarówno wyborców, jak i analityków sceny wyborczej. 
Rosnąca w siłę i bogacąca się klasa średnia oczekuje stabilności w polityce, co niestety może nie być tak oczywistą sytuacją w nadchodzących latach. Reorganizujące się elity polityczne już rozpoczęły przygotowania do kolejnych wyborów prezydenckich poszukując kandydata, który mógłby ich reprezentować. Zobaczymy czy Prabowo Subianto, który w 2024 r., będzie miał 73 lata nadal będzie chciał zrealizować swoje marzenie o prezydenturze. Na horyzoncie pojawia już się kilka kandydatur. Megawati Sukarnoputri przygotowuje swoją córkę Puan Maharani, która została w 2019 r. pierwszym speakerem-kobietą Ludowej Izby Reprezentantów. Sandiaga Uno, mimo przegranej w tych wyborach, również rozważa start, ale już jako główny kandydat. Rodzina byłego prezydenta SB Yudhoyono również chciałaby powrócić do Pałacu Prezydenckiego, wszystkie działania są przez nich skrupulatnie prowadzone. Najbliższe pięć lat będzie polem do prowadzenia bardzo ciekawej i zażartej kampanii wyborczej.

\section{Bibliografia}

Arifin E., Will hard-line Islamist influence Indonesia's election?, The Asean Post, https://theaseanpost.com/article/will-hard-line-islamism-influence-indonesias-elections.

Bland B., Indonesia's election debates: there's substance in the style, „The Interpreter” 2019.

Blank J., What Jokowi's Reelection Means for Indonesia A Vote to Preserve Hard-Earned Progress, https://www.foreignaffairs.com/articles/indonesia/2019-04-22/what-jokowis-reelection-means-indonesia.

Busch M., Old habits die hard in Indonesia's presidential clash, https://indonesiaatmelbourne.unimelb.edu.au/old-habitsdie-hard-in-indonesias-presidential-clash/. 
Kapoor K., Indonesian former general fires up masses in second run at presidency, https://www.reuters.com/article/ us-indonesia-election-prabowosubianto-pr/indonesian-former-general-fires-up-masses-in-second-run-at-presidency-idUSKCN1RQ03O.

Khidhir S., Sandiaga Uno: From loser to winner, https://theaseanpost.com/article/sandiaga-uno-loser-winner.

Kinadi B., A look ahead: 2019 Indonesia presidential election, Global Counse, https://www.global-counsel.com/insights/ blog/look-ahead-2019-indonesia-presidential-elections.

Lane M., The 2019 Indonesian Election: An Overview, „Perspective - ISEAS Yusof Ishak Institute" 2019, nr 49.

Mietzner M., How Jokowi won and democracy survived, „Journal of Democracy" 2014, vol. 25, nr 4.

Renaldi E, Shelton T., Unicorns become an unexpected symbol of Indonesia's second presidential debate, https://www.abc. net.au/news/2019-02-18/joko-widodo-indonesia-presidential-debate-prabowo-subianto/10820310.

Senkyr J., President Jokowi wins the elections in Indonesia, Konrad Adenauer Stiftung, 2019, https://www.ecoi.net/en/ file/local/2014145/190613-Indonesia-Country+report-.pdf. Sheany, Understaning 212 Movement, https://jakartaglobe.id/ context/understanding-212-movement.

Singh M., Russell J., Indonesia restricts WhatssApp, Facebook, Instagram usage following deadly riots, https://techcrunch. com/2019/05/22/indonesia-restricts-whatsapp-and-instagram.

Temby Q., Najib Burhami A., Irawanto B., Indonesia's 2019 Elections: The Key Issues, „Perspective ISEAS Yusof Ishak Institute" 2019, nr 30. 


\begin{abstract}
Abstrakt
Wybory prezydenckie z 2019 r. w Indonezji okazały się największymi wyborami prezydenckimi na świecie. Wzięło w nich około $192 \mathrm{mln}$ uprawnionych mieszkańców archipelagu. Mogli zdecydować pomiędzy dwoma kandydatami - obecnie sprawujących władzę Joko „Jokowi” Widodo oraz Prabowo Subianto. Kampania prezydencka pokazała jak jeszcze młodą i niestabilną demokracją jest Indonezja oraz jak silne wpływy na sprawowaną władzę mają elity rządowe oraz religijne. Media społecznościowe oraz łatwy i powszechny dostęp do Internetu zwrócił uwagę na rolę „fake news” w kształtowaniu całej kampanii prezydenckiej i świadomości wyborców. Nadal bardzo widoczny jest podział na wyborców z etnicznej Jawy oraz tzw. Outer Islands.
\end{abstract}

Słowa kluczowe: wybory prezydenckie, fake news, wyniki wyborów, partia polityczna, islam

\begin{abstract}
Indonesia's presidential election turned out to be the largest presidential election in the world, with about 192 million eligible residents of the archipelago. They could decide between two candidates - currently in power Joko "Jokowi" Widodo and Prabowo Subianto. The presidential campaign showed how still Indonesia is a young and unstable democracy, and how strong the government and religious elites have influence on their power. Social media and easy and universal access to the Internet drew attention to the role of "fake news" in shaping the entire presidential campaign and voters' awareness. Still is seen a division between ethnic Java and 'the Outer Islands.
\end{abstract}

Keywords: presidential election, fake news, election results, political party, islam 